\title{
BANKRUPTCY TREATMENT OF INTELLECTUAL PROPERTY ASSETS: AN ECONOMIC ANALYSIS
}

\author{
By Peter S. Menell
}

\section{TABle of CONTENTS}

I. INTRODUCTION

II. CONTRASTING APPROACHES TO ASSET MANAGEMENT: INTELLECTUAL PROPERTY LAWS VERSUS THE

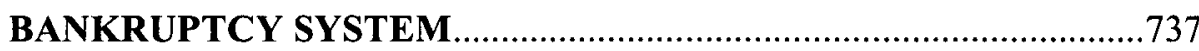

A. Intellectual Property Law: The Ex ANTe Perspective.............737

1. The Goals of Intellectual Property Law .....................................738

2. Intellectual Property Transactions ............................................741

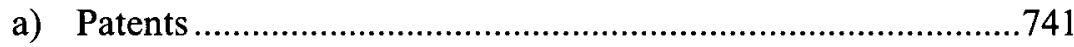

b) Copyrights..........................................................................

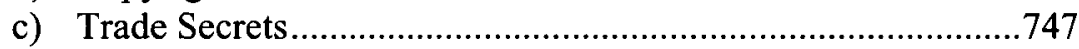

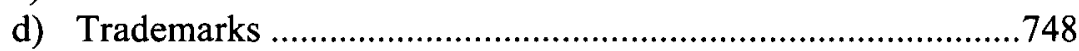

B. The Bankruptcy System: An Ex Post DebTor Perspective.......751

1. Overview of the Bankruptcy System ..........................................751

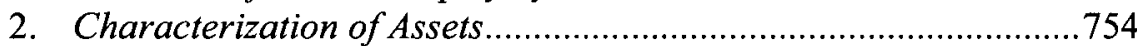

a) Sales, Assignments, and Exclusive Licenses of Intellectual Property Rights ......................................................758

b) The Classification of Mode-Specific IP Licenses ...................761

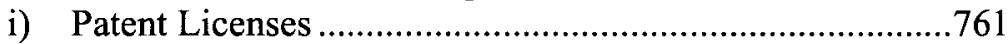

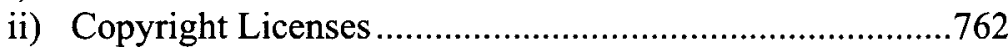

iii) Trade Secret Licenses ....................................................764

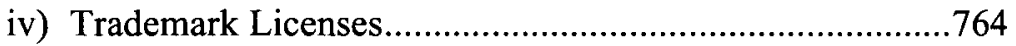

v) Software License Agreements ..........................................765

3. Resolution of the Bankrupt Estate: Dishonoring of Contract ........767

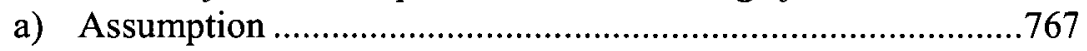

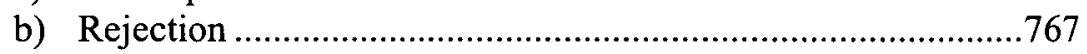

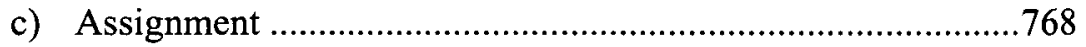

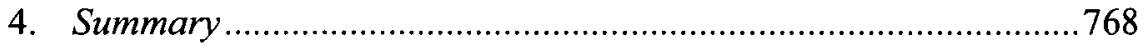

III. THE LICENSOR BANKRUPTCY PROBLEM…….............................769

(C) 2007 Peter S. Menell

$\dagger$ Professor of Law and Director, Berkeley Center for Law \& Technology, University of California at Berkeley (Boalt Hall) School of Law. I would like to thank Jesse Fried, David Nimmer, and Robert Eisenbach for comments and Carol Johns and Tom Fletcher for research assistance. 
A. THE LiMITED SCOPE OF "INTELLECTUAL PROPERTY" UNDER

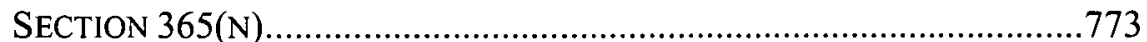

1. Trademarks and Bundled IP Licenses .......................................774

2. Foreign Copyrights ................................................................778

3. Personal Services of Recording Artists ..................................779

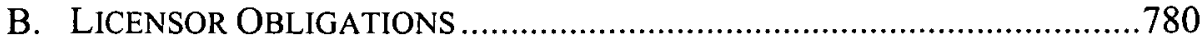

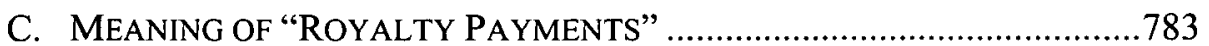

D. ASSESSMENT AND REFORM...................................................... 783

IV. THE LICENSEE BANKRUPTCY PROBLEM .............................784

A. ASSUMABILITY OF LICENSE AGREEMENTS BY REORGANIZING

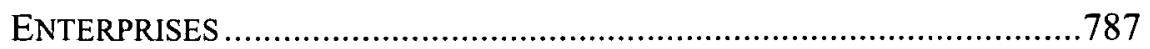

B. MODE-SPECIFIC ANALYSIS OF ASSIGNABILITY OF LICENSE

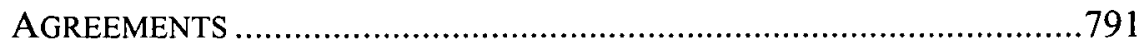

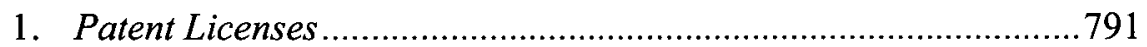

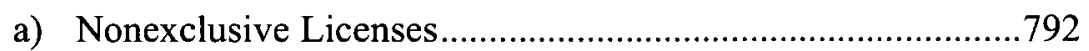

b) Exclusive Licenses........................................................794

c) Assumption of Licenses by Reorganized Debtors .................798

2. Copyright Licenses .........................................................80 80

a) Nonexclusive Licenses....................................................80

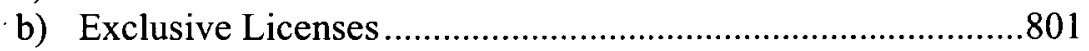

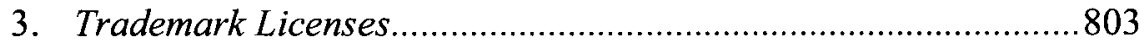

4. Trade Secret Licenses.............................................................8 809

C. AvoIdING OPPORTUNISM AND PROMOTING DEBTOR ESTATE

VALUE IN THE LICENSEE BANKRUPTCY CONTEXT ...........................810

1. Assignment to Hostile Third Party or Retention by Hostile Debtor................................................................................8 810

2. Equitable Division of Bilateral Goodwill .................................811

V. MANAGING INVESTOR RISK: SECURITIZATION OF

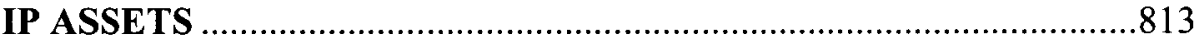

A. UCC ARTiCle 9: Default Rules For PERFECTING SECURITY

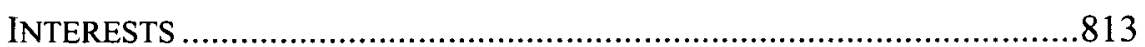

1. Attachment of Security Interests ......................................... 814

2. Perfection of Security Interests.............................................814

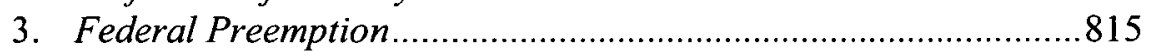

B. INTEllectual Property StatuTEs, Pre-EMPtion, AND

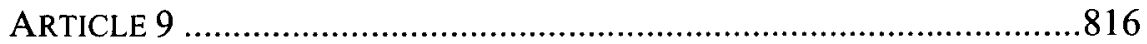

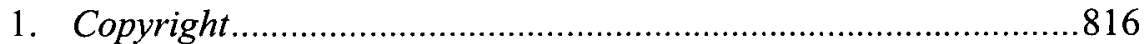

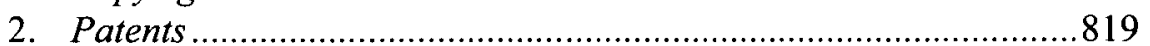

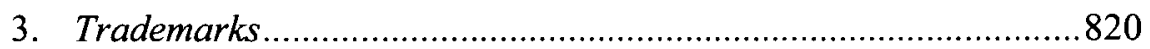

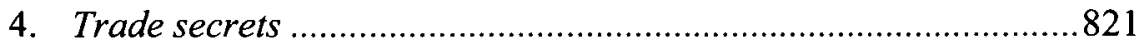

C. IMPROVING THE PROCESS FOR PERFECTING SECURITY INTERESTS IN INTELLECTUAL PROPERTY ......................................8 821

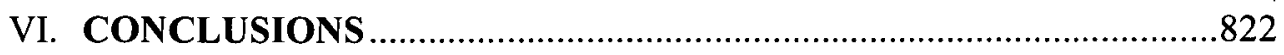


With the rise of intellectual property in the modern economy, bankruptcy treatment of intellectual property assets has taken on ever greater importance. The law in this area must balance different approaches to asset management. Viewing the world from an ex ante perspective, intellectual property laws seek to foster investment in research and development. Freedom of contract plays a central role in maximizing the potential value of intellectual property by encouraging a robust licensing market to exploit the value of intellectual creativity. By contrast, the bankruptcy system generally views asset management from an ex post standpoint, focusing narrowly on how to maximize the value of a failing or failed enterprise. Thus, bankruptcy law affords trustees and debtors substantial leeway to rescind contracts and reorder the affairs of the failed entity. This Article examines the rather complex rules governing the treatment of intellectual property assets in bankruptcy and suggests various reforms that could better promote economic efficiency.

\section{INTRODUCTION}

Over the past several decades, intellectual property has taken on an increasingly larger role in the global economy. Today, much of the value of the world's leading companies resides in their portfolios of intangible assets-ranging from the better defined forms of intellectual property (such as patents and copyrights) to the least tangible of the intangibles (trade secrets (know-how) and trademarks (the goodwill associated with a brand)). According to one source, the ratio of the value of hard assets relative to intangible assets among the major industrial companies of the world went from $62 \% / 38 \%$ in 1982 to $38 \% / 62 \%$ a decade later.'

In 2000, intangible assets and intellectual property values are clearly the most important assets of most industrial companies given the increased intensity of competition, increased rapidity of technological growth and innovation, increased reliance on legal protection of rights in intellectual property and increased enforcement of ownership rights, and increasingly sharp liability standards for infringement and misappropriation. ${ }^{2}$

As these assets have appreciated, sometimes becoming a company's most valuable assets, their importance in bankruptcy proceedings has also

1. See William J. Murphy \& Thomas Ward, Proposal for a Centralized and Integrated Registry for Security Interests in Intellectual Property, 41 IDEA 297, 301 (2002) (citing Swiss ReInSURANCE COMPANY, The Significance of InTEllectual Property ASSETS, RISKS AND INSURANCE (2000)).

2. Id. 
become critical. Sorting out how the bankruptcy system interacts with intellectual property, however, requires understanding many complex areas of law. Besides the sheer complexity of statutes like the Patent Act, Copyright Act, and the Bankruptcy Code, practitioners need to understand how the statutes interact with each other and with various state laws.

From a practical standpoint, intellectual property assets create difficult questions in two areas of bankruptcy law. First, what happens to intellectual property licenses when a company goes through bankruptcy? Many companies' key products and services depend on intellectual property licenses. For example, a pharmaceutical company often needs licenses for patented processes and compounds or its production line halts. A movie studio can only develop and distribute a pre-existing property if it has it under license. How the bankruptcy system preserves-or disruptslicensing arrangements is critical.

The importance of securitizing intellectual property assets raises the second difficult question: how can parties protect their intellectual property assets in the event of business failure, ensuring that those interests will be honored in bankruptcy? Creating security interests in intellectual property assets is one way to avoid such problems. These security interests act as insurance in the event of bankruptcy. Additionally, security interests allow intellectual property developers to use their assets as collateral to get financing despite their lack of tangible assets. Bankruptcy law touches on security interests as well. One must understand the interaction between bankruptcy and security interests in order to use those interests effectively to protect intellectual property rights in a bankruptcy proceeding.

This Article begins by exploring the friction between the intellectual property laws-which use an ex ante perspective to promote efficient levels of investment in the development and exploitation of innovative and creative works - and the bankruptcy system - which views assets from an ex post perspective to maximize the value of a debtor's estate. It then examines the three principal tensions at the intersection of intellectual property law and the bankruptcy system: (1) when the licensor of intellectual property goes bankrupt and the trustee of the debtor estate seeks to rescind a license agreement; (2) when an intellectual property licensee enters bankruptcy and the trustee, attempting to maximize the value of the debtor estate, seeks to transfer a license to a third party that may undermine the licensor's desires; and (3) the challenge of securitizing investments in creative enterprises where the main value lies in intangible assets. The Article explains how changes in the law have ameliorated some of the tensions between intellectual property law and the bankruptcy system, but notes several distinct problems that remain. It recommends several changes to 
better promote economic efficiency in the bankruptcy treatment of intellectual property assets.

\section{CONTRASTING APPROACHES TO ASSET MANAGEMENT: INTELLECTUAL PROPERTY LAWS VERSUS THE BANKRUPTCY SYSTEM}

The intellectual property laws and the bankruptcy system reflect very different perspectives on the management of assets. The intellectual property laws are generally concerned with asset creation. Therefore, they encourage conditions that promote investment in research and development, as well as the maximization of value that can be derived from such assets. Much of the value of intellectual property flows from licensing goods and services. Freedom of contract therefore plays a central role in maximizing the potential value of intellectual property by encouraging a robust licensing market to exploit the value of intellectual creativity.

By contrast, the bankruptcy system views economic activity from the standpoint of maximizing the value of a failing or failed enterprise. It seeks to maximize the value of the remaining assets and capacities of the troubled entity. In order to accomplish this, bankruptcy law affords trustees and debtors substantial leeway to rescind contracts and reorder the affairs of the entity. Therein lay the tensions with the intellectual property laws.

As background for the analysis of these tensions, this Part first traces the goals of the intellectual property laws as well as their specific treatment of licensing. It then examines the main contours of the bankruptcy system and its general perspective on honoring (or more appropriately, dishonoring) contractual obligations. The following Sections explore the principal tensions between these two systems.

\section{A. Intellectual Property Law: The Ex Ante Perspective}

The intellectual property landscape can be divided into two general areas: those modes of protection focused principally on promoting innovation and creativity and those aimed at protecting the integrity of the marketplace. ${ }^{3}$ The former purpose provides the impetus and guide for patent and copyright law, and, to a lesser extent, trade secret law. The latter finds expression in trademark and unfair competition law.

3. See generally Peter S. Menell \& Suzanne Scotchmer, Intellectual Property Law, in HANDBOOK OF LAW AND ECONOMICS (A. Mitchell Polinsky \& Steven Shavell eds., forthcoming 2007). 


\section{The Goals of Intellectual Property Law}

The Intellectual Property Clause of the U.S. Constitution succinctly and directly expresses the motivation behind patent and copyright law by authorizing Congress " $[\mathrm{t}] \mathrm{o}$ promote the Progress of Science and useful Arts, by securing for limited Times to Authors and Inventors the exclusive Right to their respective Writings and Discoveries." 4 As the Supreme Court has explained, "[t]he economic philosophy behind [this clause] is the conviction that [it] is the best way to advance public welfare through the talents of authors and inventors in 'Science and useful Arts.' Sacrificial days devoted to such creative activities deserve rewards commensurate with the services rendered." ${ }^{, 5}$ The Court elaborated further in Bonito Boats, Inc. v. Thunder Craft Boats, Inc.:

The [Intellectual Property] Clause itself reflects a balance between the need to encourage innovation and the avoidance of monopolies which stifle competition without any concomitant advance in the "Progress of Science and useful Arts." [T]he Clause contains both a grant of power and certain limitations upon the exercise of that power. Congress may not create patent monopolies of unlimited duration, nor may it "authorize the issuance of patents whose effects are to remove existent knowledge from the public domain, or to restrict free access to materials already available." From their inception, the federal patent laws have embodied a careful balance between the need to promote innovation and the recognition that imitation and refinement through imitation are both necessary to invention itself and the very lifeblood of a competitive economy. ${ }^{6}$

To understand why the Framers thought exclusive rights in inventions and creations would promote the public welfare, consider what would happen absent any sort of intellectual property protection. Invention and creation often require the investment of resources, such as the time of an author or inventor, expenditures on facilities, prototypes, and supplies. In a private market economy, economically motivated individuals will not invest in invention or creation unless the expected return exceeds the costthat is, unless they can reasonably expect to make a profit from the endeavor. To profit from a new idea or a work of authorship, the creator

4. U.S. ConsT. art. I, $\S 8, \mathrm{cl} .8$.

5. Mazer v. Stein, 347 U.S. 201, 219 (1954).

6. 489 U.S. 141,146 (1989) (citation omitted). 
must be able either to sell it to others, or to put it to some use which provides a comparative advantage in the marketplace.

But ideas are notoriously hard to control in the absence of some form of legal protection. Even if the idea is one that the creator can use herself - to boost productivity in her business, for example-she will reap a reward from that idea only to the extent that her competitors do not find out about it. A creator who depends on secrecy for value lives in constant peril of discovery and disclosure. Competitors may steal the idea or learn of it from an ex-employee. They may be able to figure it out by watching the creator's production process or by examining the products sold. Finally, they may come upon the idea on their own or discover it in the published literature. In all of these cases, the secrecy value of the idea is irretrievably lost.

Authors (and publishers) of works of creative expression face a distinct but related problem. Works of creative expression can require substantial amounts of time on research and great expenditures of resources. A novel can take years to conceive, research, and write. A major motion picture can cost tens of millions of dollars or more to produce. In order to derive value from their works, creators must make them available to the public-through publishing, performance, or ancillary means (such as licensing of merchandise derived from the creative work). But once the work is available, others can make copies. Because these others do not incur most of the costs of the production, they can earn a profit by selling the work at substantially lower cost than the creator.

The creator who wants to sell her idea is in an even more difficult position. Selling information requires disclosing it to others. Once the information has been disclosed outside a small group, however, it is extremely difficult to control. Information has the characteristics of what economists call a "public good"-it may be "consumed" by many people without depletion, and it is difficult to identify those who will not pay and prevent them from using the information. For example, once the idea of the intermittent windshield wiper is disclosed, others can imitate its design relatively easily.

Patents and copyrights directly address the problem of appropriating a stream of income from investments in innovation and creative expression. Subject to various exceptions, limitations, and defenses, these modes of protection effectively prohibit the use and sale of protected works without

7. The latter may occur, for example, where an idea for a more efficient machine is used to reduce the cost of producing goods, allowing the owner of the idea to compete more effectively in selling those goods. 
the authorization of the intellectual property owner. In this way, innovators (and those who invest in them) can prevent others from directly competing with them for the period that the works receive protection. The creation of exclusive rights can, however, reduce competition. For that reason, patent law and copyright law impose some threshold requirements upon acquisition of rights and limit the scope of protection in various ways. We will examine these attributes below.

Trade secret law also seeks to promote innovation, ${ }^{8}$ although it accomplishes this objective in a very different manner than patent law. Notwithstanding the advantages of obtaining a patent - an exclusive right to practice an invention for a designated period of time-many innovators prefer to protect their innovation through secrecy. They may feel that the cost and delay of seeking a patent are too great or that they can more effectively profit from their investment through secrecy. They might also believe that the invention can best be exploited over a longer period of time than a patent would allow.

Without any special legal protection, however, the secretive inventor runs the risk that an employee (or a thief) will disclose the invention. Once the idea is released, it will be "free as the air." "Such a predicament would lead any inventor seeking to rely upon secrecy to spend an inordinate amount of resources on building high and impervious fences around their research facilities and greatly limiting the number of people with access to the proprietary information. Although trade secret law does not limit the use of ideas once they have become publicly known, it does significantly reduce the costs of protecting secrets within the confines of the research and commercial environment. An inventor who takes reasonable steps to maintain secrecy can obtain strong remedies against individuals within the laboratory or commercial enterprise and those subject to contractual limitations for misappropriation of trade secrets. ${ }^{10}$

Trademark law and related unfair competition doctrines flow from a very different primary purpose: protection of the integrity of the marketplace. In fact, the first federal trademark statute (passed in 1870), which grounded protection for trademark rights on the Intellectual Property Clause of the Constitution, was struck down by the Supreme Court because the statute protected marks regardless of any novelty or original-

8. Trade secret law seeks to promote standards of commercial ethics as well.

9. See International News Serv. v. Associated Press, 248 U.S. 215, 250 (1918) (Brandeis, J., dissenting) ("The general rule of law is, that the noblest of human productions-knowledge, truths ascertained, conceptions, and ideas-became, after voluntary communication to others, free as the air to common use.").

10. See generally RESTATEMENT (THIRD) OF UNFAIR COMPETITION $\S \S 38-45$ (1995). 
ity. ${ }^{11}$ Congress has since based federal trademark protection on the Commerce Clause, requiring that marks be used in interstate commerce. Trademark law facilitates and enhances consumer decisions by protecting names, logos, words, phrases, symbols, sounds, trade dress, product configuration, and other means of designating the source of commercial products or services. In so doing, trademark law encourages firms to supply quality products and services and invest in building the "goodwill" surrounding a brand name. In this way, it plays some role in encouraging innovation. Nonetheless the protection of a mark turns on its distinctiveness and the extent to which consumers associate it with a source of goods, not its inventiveness.

\section{Intellectual Property Transactions}

In order to understand the tension between intellectual property and bankruptcy law, it is necessary to understand the importance of licensing in markets for creative enterprise. Inventors and creators are often not best situated to commercialize their creativity. Licensing markets allow better situated players to adapt and exploit creative works. The robustness of those markets plays a critical role in encouraging investment in creative activities. Therefore, intellectual property law generally encourages freedom of contract in the licensing of intellectual property. The courts and legislatures have long considered patents, copyrights, and trademarks to be forms of "property" and have characterized them as such. ${ }^{12}$

a) Patents

The Patent Act expressly declares that "patents shall have the attributes of personal property" 13 and "shall be assignable in law by an instrument in writing." "It states further that the patentee (or his assigns) may "grant and convey an exclusive right" under his patent "to the whole or

11. The Trade-Mark Cases, 100 U.S. 82, 94 (1879).

12. See Justin Hughes, Copyright and Incomplete Historiographies: Of Piracy, Propertization, and Thomas Jefferson, 79 S. CAL. L. REV. 993 (2006) (demonstrating a long history of analogizing copyright to property). That intellectual property is characterized as "property" does not mean that it is treated the same as land and other tangible forms of property. See Peter S. Menell, The Property Rights Movement's Embrace of Intellectual Property: True Love or Doomed Relationship?, 34 ECOLOGY L.Q. (forthcoming 2007).

13. See 35 U.S.C. $\S 261$ (2000); see also Festo Corp. v. Shoketsu Kinzoku Kogyo Kabushiki Co., 535 U.S. 722, 730,739 (2002) (noting that a patent "is a property right" and that patent rights constitute "the legitimate expectations of inventors in their property"); Fla. Prepaid Postsecondary Educ. Expense Bd. v. College Sav. Bank, 527 U.S. 627,642 (1999) ("Patents . . have long been considered a species of property.").

14. See 35 U.S.C. $\S 261(2000)$. 
any specified part of the United States." 15 As set forth in Waterman $v$. Mackenzie, an agreement is a sale (or assignment) of patent rights only if it conveys " 1 . the whole patent, comprising the exclusive right to make, use and sell the invention; 2 . an undivided share of that exclusive right; or 3 . an exclusive right to practice the invention within a specified territory." 16 Short of an outright assignment, a patent owner is generally free to license rights under the patent as he wishes (subject to competition policy constraints ${ }^{17}$ ). Such licenses can be express or implied. "Unless the writing conveys some or all of the right to exclude others from practicing the invention, it will not convey an interest in the patent, but is a mere license." "It has been well-established under federal common law that nonexclusive licenses cannot be assigned without the authorization of the licensor. ${ }^{19}$ There is no definitive ruling dealing with the assignability of exclusive patent licenses without licensor consent. Early on, however, the federal courts held that a patent license is "not assignable unless expressly made so" in the licensing agreement. ${ }^{20}$

15. Id.

16. In re Access Beyond Techs., Inc., 237 B.R. 32, 44 (Bankr. D. Del. 1999) (citing Waterman v. Mackenzie, 138 U.S. 252, 255-56 (1891)).

17. See 35 U.S.C. $\$ 271$ (d) (2000) (imposing statutory limitations on patent misuse doctrine to harmonize better with antitrust law); Dawson Chem. Co. v. Rohm \& Haas Co., 448 U.S. 176 (1980); Motion Picture Patents Co. v. Universal Film Mfg. Co., 243 U.S. 502, 519 (1917) (invalidating license on grounds of anticompetitive patent misuse). See generally Robert P. MERges, Peter S. MENELl \& MARK A. LeMLey, INTEllectual PROPERTY IN THE NEW TECHNOLOGICAL AGE 326-30 (4th ed. 2006).

18. In re Access Beyond Techs., Inc. 237 B.R. 32, 44 (Bankr. D. Del. 1999) (citing Waterman v. Mackenzie, 138 U.S. 252, 256 (1891)).

19. See PPG Indus., Inc. v. Guardian Indus. Corp., 597 F.2d 1090, 1093 (6th Cir. 1979); Unarco Indus., Inc. v. Kelley Co., 465 F.2d 1303, 1306 (7th Cir. 1972); Rock-Ola Mfg. Corp. v. Filben Mfg. Co., 168 F.2d 919, 922-23 (8th Cir. 1948).

20. See Hapgood v. Hewitt, 119 U.S. 226, 233-34 (1886); Oliver v. Rumford Chem. Works, 109 U.S. 75, 82 (1883) (declaring that "the instrument of [a patent] license is not one which will carry the right conferred to any one but the licensee personally, unless there are express words to show an intent to extend the right to an executor, administrator, or assignee, voluntary or involuntary"); Troy Iron \& Nail Factory v. Corning, 55 U.S. 193, 216 (1852) (declaring patent licenses are not assignable without owner's consent). For more recent affirmation of this doctrine, see Perlman v. Catapult Entm't (In re Catapult Entm't), 165 F.3d 747, 750 (9th Cir. 1999); Institut Pasteur v. Cambridge Biotech Corp., 104 F.3d 489, 492 (1st Cir. 1997); Unarco Indus., 465 F.2d at 1306. As noted infra note 211 , some commentators have raised questions as to whether this invocation of federal common law should prevail in the aftermath of Erie R.R. v. Tompkins, 304 U.S. 64 (1938). The U.S. Supreme Court has not had occasion to revisit the viability of this federal common law rule. 
The Patent Act establishes a recordation system for "assignment[s], grant[s] or conveyance[s]" of patents. ${ }^{21}$ By recording such instruments with the PTO "within three months from its date or prior to the date of [a] subsequent purchase or mortgage," 22 the acquiring party is protected against an assertion of title by a subsequent purchaser or mortgagee. If the transferee fails to record, however, it risks losing its interest to a subsequent acquirer or mortgagee who paid valuable consideration and lacked notice of the prior transfer of title. Although the PTO permits the recording of licenses, ${ }^{23}$ the "bona fide purchaser" defense is available only to licensees holding "“all substantial rights' under the patent." 24 This excludes nonexclusive licenses and likely applies to some exclusive licenses as well.

b) Copyrights

Similarly, copyright law generally supports free alienability and licensing. At least with regard to alienability, this was not always so. Under the 1909 Act, a copyright was considered an indivisible property interest which could not be divided through contract. The rationale for the "indivisibility" doctrine was to protect infringers from being harassed by successive law suits by holders of different sticks in the copyright bundle. Therefore, only the owner of the intact bundle could enforce the copyright. This rule did not, however, prevent the copyright from being licensed. Nonetheless, the indivisibility doctrine caused a number of undesirable effects. Some works lost copyright because publishers occasionally used the wrong name on copyright notices, and many copyright interest holders were prevented from enforcing their rights.

The 1976 Act abandoned the indivisibility doctrine. Section 201(d) now provides:

(d) Transfer of Ownership--

(1) The ownership of a copyright may be transferred in whole or in part by any means of conveyance or by operation of law, and may be bequeathed by will or pass as personal property by the applicable laws of intestate succession.

21. 35 U.S.C. $\S 261(2000)$.

22. Id.

23. See 37 C.F.R. § 3.11(a)-(b) (2005).

24. Rhone Poulenc Agro, S.A. v. DeKalb Genetics Corp., 284 F.3d 1323, 1334 (Fed. Cir. 2002) (quoting Textile Prods., Inc. v. Mead Corp., 134 F.3d 1481, 1484 (Fed. Cir. 1998)). 
(2) Any of the exclusive rights comprised in a copyright, including any subdivision of any of the rights specified by section 106, may be transferred as provided by clause (1) and owned separately. The owner of any particular exclusive right is entitled, to the extent of that right, to all of the protection and remedies accorded to the copyright owner by this title. ${ }^{25}$

The Copyright Act defines "transfer of copyright ownership" broadly to include:

an assignment, mortgage, exclusive license, or any other conveyance, alienation, or hypothecation of a copyright or of any of the exclusive rights comprised in a copyright, whether or not it is limited in time or place of effect, but not including a nonexclusive license. ${ }^{26}$

This definition has been interpreted to encompass security interests. ${ }^{27}$

This broad definition of "transfer of copyright ownership" makes the question of whether licenses are assignable more difficult than in patent law. Where a license agreement limits assignability, such provisions will be enforced. Where an agreement is silent, the courts have imported the federal common law non-assignability doctrine from patent law to hold that a nonexclusive copyright license "is personal to the transferee . . . and the licensee cannot assign it to a third party without the consent of the copyright owner." 28 Courts are split, however, over the assignability of exclusive licenses. As noted above, the 1976 Copyright Act specifically defines the granting of an exclusive license of any of the exclusive rights comprised in copyright as a "transfer of copyright ownership.", 29 Furthermore, section 201(d)(1) of the Act states that "ownership of a copyright may be transferred in whole or in part by any means of conveyance or by operation of law." Section 201(d)(2) provides that "[a]ny of the exclusive

25. 17 U.S.C. $\S 201(d)(2000)$.

26. 17 U.S.C. $\S 101$ (2000 \& Supp. 2004).

27. See infra Section II.B.1.

28. See Harris v. Emus Records Corp., 734 F.2d 1329, 1333-34 (9th Cir. 1984) (based on 1909 Copyright Act); In re Patient Educ. Media, Inc., 210 B.R. 237, 240 (Bankr. S.D.N.Y. 1997) (holding, under the 1976 Copyright Act regime, that the "conclusion and policy analysis in [Everex, 89 F.3d at 673] applies with equal force in the analogous area of copyright law"); see also Michaels v. Internet Entm't Group, Inc., 5 F. Supp. 2d 823, 834 (C.D. Cal. 1998); Seawind v. Creed Taylor, Inc. (In re Creed Taylor, Inc.), 10 B.R. 265, 267-68 (Bankr. S.D.N.Y. 1981) (upholding an anti-assignment clause in an exclusive license to manufacture and distribute sound recordings in part because of the "personal nature of certain licensing arrangements").

29. 17 U.S.C. $\S 101$ (2000 \& Supp. 2004). 
rights comprised in a copyright, including any subdivision of any of the rights specified by section 106, may be transferred ... and owned separately." Reading these provisions to provide that the holder of an exclusive license is entitled to all the rights and protections of the copyright owner to the extent of the license, including the right to transfer such rights, ${ }^{30}$ several courts have held that the exclusive licensee may freely transfer his rights. ${ }^{31}$ A recent Ninth Circuit decision, however, reads the Copyright Act to dictate the opposite conclusion. ${ }^{32}$

The Ninth Circuit in Gardner v. Nike reaffirmed its prior decision that "copyright licenses (whether exclusive or not) were 'not transferable as a matter of law" "under the 1909 Act. ${ }^{33}$ Only an assignment of the entire copyright could be transferred under the 1909 regime based on the doctrine of indivisibility ${ }^{34}$ and the policy concerns animating that Act. Although recognizing that the 1976 Act introduced the concept of divisibility, the court in Gardner read subsection 201(d)(1) narrowly to apply only to owners of the entire copyright, affording them the power to apportion their interest. It read the more specific second sentence of subsection $201(\mathrm{~d})(2)^{35}$ to limit the rights of exclusive licensees to the "protection and remedies" of the Copyright Act. On this basis, it concluded that the particular transfer right of section 201(d)(1) and the first sentence of subsection 201(d)(2) apply only to copyright owners, not exclusive licensees. The court similarly dismissed the transferability argument based on the definition of "transfer of copyright ownership" in section 101 on the statutory interpretation principle that more specific provisions take precedence over the more general. The court bolstered its arguments by referring to the same policy that favors non-assignability of patent licenses without licensor consent: the promotion of creativity through control of licensing by the intellectual property owner.

30. 17 U.S.C. $\S 201(d)(2)(2000)$. See generally 3 Melville B. NimMER \& DAVID NIMMER, NIMMER ON COPYRIGHT $\S 10.02[A]$ (2006).

31. See I.A.E., Inc. v. Shaver, 74 F.3d 768, 775 (7th Cir. 1996); In re Patient Educ. Media, 210 B.R. at 240.

32. See Gardner v. Nike, Inc., 279 F.3d 774 (9th Cir. 2002).

33. Id. at 777-78.

34. The doctrine of indivisibility prohibited a copyright owner from dividing the "bundle of rights." 3 NIMMER ON COPYRIGHT, supra note $30, \S 10.01$ [A].

35. 17 U.S.C. $\S 201(\mathrm{~d})(2)$ provides:

Any of the exclusive rights comprised in a copyright, including any subdivision of any of the rights specified by section 106, may be transferred as provided by clause (1) and owned separately. The owner of any particular exclusive right is entitled, to the extent of that right, to all of the protection and remedies accorded to the copyright owner by this title. 
A transfer of copyright ownership must be in writing and signed by the transferor. ${ }^{36}$ Section 205 establishes a detailed system for recording copyright transfers and resolving disputes over conflicting transfers:

(a) Conditions for Recordation.-Any transfer of copyright ownership or other document pertaining to a copyright may be recorded in the Copyright Office if the document filed for recordation bears the actual signature of the person who executed it, or if it is accompanied by a sworn or official certification that it is a true copy of the original, signed document.

(b) Certificate of Recordation.-The Register of Copyrights shall, upon receipt of a document as provided by subsection (a) and of the fee provided by section 708 , record the document and return it with a certificate of recordation.

(c) Recordation as Constructive Notice--Recordation of a document in the Copyright Office gives all persons constructive notice of the facts stated in the recorded document, but only if-

(1) the document, or material attached to it, specifically identifies the work to which it pertains so that, after the document is indexed by the Register of Copyrights, it would be revealed by a reasonable search under the title or registration number of the work; and

(2) registration has been made for the work.

(d) Priority Between Conflicting Transfers.-As between two conflicting transfers, the one executed first prevails if it is recorded, in the manner required to give constructive notice under subsection (c), within one month after its execution in the United States or within two months after its execution outside the United States, or at any time before recordation in such manner of the later transfer. Otherwise the later transfer prevails if recorded first in such manner, and if taken in good faith, for valuable consideration or on the basis of a binding promise to pay royalties, and without notice of the earlier transfer.

(e) Priority Between Conflicting Transfer of Ownership and Nonexclusive License.-A nonexclusive license, whether recorded or not, prevails over a conflicting transfer of copyright ownership if the license is evidenced by a written instrument signed by the owner of the rights licensed or such owner's duly authorized agent, and if-

36. 17 U.S.C. $\S 204$ (a) (2000). The 1909 Act required that transfers of copyright be in writing. 17 U.S.C. $\S 28$ (1909 Act). Since licenses-exclusive or nonexclusive-were not considered transfers under the indivisibility doctrine, no writing was required. These rules still apply to grants made prior to January $1,1978$. 
(1) the license was taken before execution of the transfer; or

(2) the license was taken in good faith before recordation of the transfer and without notice of it.

The rules determining priority among conflicting transfers in section 205(d) above apply only where a work has been registered and the transfer duly recorded, the transfer has been made in good faith (i.e., without actual notice of a prior transfer), and valuable consideration has been paid (e.g., not a gift or bequest). Recording the transfer of an unregistered work does not provide a basis for priority of transfer.

\section{c) Trade Secrets}

Unlike patent and copyright law, which protect the innovator against the public at large, trade secret law is limited to protecting the secrecy of the information and not the information itself. With patents and copyrights, there is a relatively well-defined asset to discuss - the claims of the patent, or the work of authorship. Trade secret law is somewhat less focused on specific assets. There may well be a specific "asset," such as a formula or a blueprint, but trade secret law covers more amorphous subject matterinformation. And the nature of trade secret protection relates as much to the subject matter as to the precautions of the trade secret "owners" and the means by which the defendant acquired the information. Therefore, it is useful to examine the extent to which trade secrets constitute property "assets."

The Supreme Court appears to have adopted a "property" view of trade secrets in Ruckelshaus $v$. Monsanto $\mathrm{Co}^{37}$ There, the Court faced the question of whether a federal law that required Monsanto to publicly disclose its trade secrets was a "taking of private property" for which the Fifth Amendment required compensation. The Court found that trade secrets were "property," reasoning in part that " $[\mathrm{t}]$ rade secrets have many of the characteristics of more tangible forms of property. A trade secret is assignable. A trade secret can form the res of a trust, and it passes to a trustee in bankruptcy." 38 Treatment of trade secrets as property rights vested in the trade secret "owner" is consistent with a view of trade secrets law as providing an additional incentive to innovate, beyond those provided in patent law. The Supreme Court has offered some support for this view as well, in cases such as Kewanee Oil Co. v. Bicron Corp. ${ }^{39}$

A powerful alternate explanation for much of trade secret law is what might be described as a "duty-based" theory, or "the maintenance of

37. 467 U.S. 986, $1001-04$ (1984).

38. Id. at $1002-04$.

39. 416 U.S. $470,481-85$ (1974). 
commercial morality." ${ }^{40}$ The Supreme Court adopted this view in a famous early decision in which, unlike Monsanto, it was called upon to actually construe the trade secret laws:

The word "property" as applied to trademarks and trade secrets is an unanalyzed expression of certain secondary consequences of the primary fact that the law makes some rudimentary requirements of good faith. Whether the plaintiffs have any valuable secret or not, the defendant knows the facts, whatever they are, through a special confidence that he accepted. The property may be denied, but the confidence cannot be. Therefore the starting point for the present matter is not property or due process of law, but that the defendant stood in confidential relations with the plaintiffs ... ${ }^{41}$

Closely related to this "breach of confidence" theory of trade secrets is a contract perspective. While not always applicable, many trade secret cases arise out of a "duty" that is explicitly stated in a contract, such as a technology license or an employment agreement. The tort-based theory of breach of duty merges in those cases with a standard common-law style action for breach of contract. Whether trade secret law is best understood as a property regime or a tort/contract regime, however, a trade secret is property in bankruptcy.

The Uniform Trade Secrets Act, enacted in forty states and the District of Columbia, ${ }^{42}$ does not provide any special rules for ownership of trade secrets. Therefore, ownership is determined though contract lawtypically employment and licensing agreements.

Trade secrets can be freely licensed, although it is essential that such agreements ensure that the information remain secret. The provisions of such agreements generally prohibit assignment of the license (and hence, the trade secret) without the consent of the licensor. There is no specialized process for recording transfers of trade secret rights.

d) Trademarks

Trademarks-words, phrases, logos, and symbols that producers use to identify their goods and services-are protected by both federal law (the Lanham $\mathrm{Act}^{43}$ ) and state law. ${ }^{44}$

40. 1 Melvin Jager, Trade Secrets LaW $\$ 1.03$, at 1-4 (2002).

41. E.I. du Pont \& Co. v. Masland, 244 U.S. 100, 102 (1917).

42. See Restatement (Third) OF Unfair Competition $\S 39$, at 437-38 (1995) (listing state statutes). Some jurisdictions have amended the UTSA in minor ways.

43. See 15 U.S.C. $\S \S 1051-1141$ (2000 \& Supp. 2004). Federal trademark law is often referred to in cases by the original section numbers of the Lanham Act, $\S \S 1-74$. 
These marks are essential to many business forms. Franchising is perhaps the most vivid example. The McDonald's or Subway restaurant chains are built upon the assurance to consumers that they will receive a particular quality of goods at restaurants bearing the associated trademark. Vast investments are made in developing businesses around particular licensed trademarks. Thus, trademark licenses serve a critical role in investment and consumer welfare.

For these reasons, trademark law has highly developed jurisprudence surrounding trademark licensing. Due to the distinctive nature of trademarks as means for communicating the source of goods and services, trademarks cannot be transferred as simply as a patent or a copyright. As the Supreme Court observed long ago,

There is no such thing as property in a trade-mark except as a right appurtenant to an established business or trade in connection with which the mark is employed. The law of trade-marks is but a part of the broader law of unfair competition; the right to a particular mark grows out of its use, not its mere adoption; its function is simply to designate the goods as the product of a particular trader and to protect his good will against the sale of another's product as his; and it is not the subject of property except in connection with an existing business. ${ }^{45}$

44. In contrast to the federal patent and copyright acts, the Lanham Act does not preempt state trademark protection. Several provisions refer to the continued effect of state trademark law. See 15 U.S.C. $\$ 1065,1115$ (b)(5) (2000 \& Supp. 2004); Golden Door, Inc. v. Odisho, 646 F.2d 347, 351-52 (9th Cir. 1980); Mariniello v. Shell Oil Co., 511 F.2d 853, 857-58 (3d Cir. 1975); Nikon, Inc. v. Ikon Corp., 803 F. Supp. 910, 925-26 (S.D.N.Y. 1992); Plasticolor Molded Prods. v. Ford Motor Co., 713 F. Supp. 1329, 1346 (C.D. Cal. 1989), vacated, 767 F. Supp. 1036 (C.D. Cal. 1991); Mead Data Cent., Inc. v. Toyota Motor Sales, U.S.A., Inc., 702 F. Supp. 1031, 1040-41 (S.D.N.Y. 1988), rev'd on other grounds, 875 F.2d 1026 (2d Cir. 1989); cf. Bonito Boats, Inc. v. Thunder Craft Boats, Inc., 489 U.S. 141, 156-57 (1989). Some courts, however, hold that state statutes directed at the same types of conduct as the Lanham Act are preempted. See Three Blind Mice Designs Co. v. Cyrk, Inc., 892 F. Supp. 303, 309 (D. Mass. 1995) (holding that state anti-dilution statutes are "wholly preempted" to the extent that they seek to regulate competitive goods directly). But see Federal Trademark Dilution Act of 1995, H.R REP. No. 104-374 (1995), as reprinted in 1996 U.S.C.C.A.N. 1029, 1035 ("It is important to note that the proposed federal dilution statute would not preempt state dilution laws."). Since federal and state trademark and unfair competition laws follow the same contours, we will focus here on federal law.

45. United Drug Co. v. Theodore Rectanus Co., 248 U.S. 90, 97 (1918) (citing Hanover Star Milling Co. v. Metcalf, 240 U.S. 403, 412-14 (1916)). 
Therefore, a trademark may only be assigned along with the goodwill of the business in which the mark is used. ${ }^{46}$ Although earlier cases applied this rule quite strictly and required the sale of tangible assets along with the trademark, ${ }^{47}$ more recent cases have relaxed this requirement, ${ }^{48}$ partly in recognition of the increased frequency and importance of trademark licenses. In some contexts, merely relinquishing the right to do business under the trademark to the assignee may be a sufficient transfer of the trademark owner's business. ${ }^{49}$

Similarly, any licenses of trademarks - whether exclusive or nonexclusive-must be supervised by the trademark owner in order to avoid abandoning the mark. ${ }^{30}$ The Lanham Act requires trademark licensors to control "the nature and quality of the goods or services" sold by licensees. ${ }^{51}$ Due to the importance of supervising licensees, trademark licenseswhether nonexclusive or exclusive-may not be assigned without the licensor's consent. ${ }^{52}$ As with patent law, the Lanham Act establishes a sys-

46. See 15 U.S.C. $\S 1060$ (a) (2000 \& Supp. 2004). Assignment of a trademark without the goodwill to which the trademark is attached constitutes an assignment "in gross" and is invalid. See Sugar Busters, L.L.C. v. Brennan, 177 F.3d 258, 265 (5th Cir. 1999); Marshak v. Green, 746 F.2d 927, 929 (2d Cir. 1984); Greenlon, Inc. of Cincinnati v. Greenlawn, Inc., 542 F. Supp. 890, 893 (S.D. Ohio 1982).

47. See, e.g., PepsiCo, Inc. v. Grapette Co., 416 F.2d 285, 290 (8th Cir. 1969).

48. See, e.g., In re Roman Cleanser Co., 802 F.2d 207, 208-09 (6th Cir. 1986); Glamorene Prods. Corp. v. Procter \& Gamble Co., 538 F.2d 894, 895-96 (C.C.P.A. 1976).

49. See, e.g., Greenlon, 542 F. Supp. at 895; see also Money Store v. Harriscorp Fin., Inc., 689 F.2d 666, 670, 675-78 (7th Cir. 1982); H \& J Foods, Inc. v. Reeder, 477 F.2d 1053, 1055 (9th Cir. 1973).

50. See Gorenstein Enters. v. Quality Care-USA, Inc., 874 F.2d 431, 435 (7th Cir. 1989).

51. See 15 U.S.C. $\S \S 1055,1127$ (2000 \& Supp. 2004); Taco Cabana Int'l, Inc. v. Two Pesos, Inc., 932 F.2d 1113, 1121-22 (5th Cir. 1991), aff'd, 505 U.S. 763 (1992) (noting that licensor exercised adequate control to ensure quality of licensee's product); Oberlin v. Marlin Am. Corp., 596 F.2d 1322, 1327 (7th Cir. 1979); Dawn Donut Co. v. Hart's Food Stores, Inc., 267 F.2d 358, 366-69 (2d Cir. 1959) (Lumbard, J., dissenting in part).

52. A leading trademark law commentator observes that although case law on assignability of marks is sparse, a licensed mark is personal to the licensee and cannot be assigned unless the license states otherwise. See 4 J. THOMAS MCCARTHY, MCCARTHY ON TRADEMARKS AND UNFAIR COMPETITION $\S 25.33$ (4th ed. rev. 2006); Miller v. Glenn Miller Prods., 318 F. Supp. 2d 923 (C.D. Cal. 2004) ("Although the Ninth Circuit has not addressed whether the sub-licensing rule applies to trademark licenses, the courts that have addressed the issue have uniformly held it does, and thus that a trademark licensee may not sub-license a mark without express permission from the licensor."); Tap Publ'ns, Inc. v. Chinese Yellow Pages (New York), Inc., 925 F. Supp. 212, 218 (S.D.N.Y. 1996) (barring assignment of exclusive trademark license that was silent on assignment without 
tem for recording assignments, but not licenses, of registered trademarks. $^{53}$

\section{B. The Bankruptcy System: An Ex Post Debtor Perspective}

Bankruptcy law seeks to preserve the on-going value of failing enterprises and maximize the economic stake of their creditors. ${ }^{54}$ In order to effectuate these goals, the bankruptcy system generally supports the assignability and fungibility of assets (including executory contracts such as licenses) so as to generate as much value and flexibility as possible to turn around the bankrupt enterprise. Bankruptcy law also constrains freedom of contract by nullifying most agreements that would restrict the trustee's flexibility to maximize the value of the debtor's estate. In so doing, bankruptcy law generally takes an ex post view of economic relationships and values.

\section{Overview of the Bankruptcy System}

Congress established the modern bankruptcy system with the Bankruptcy Reform Act of 1978 (commonly referred to as the "Bankruptcy Code"), although the Bankruptcy Code has been significantly amended since that time. The Bankruptcy Courts are part of the District Courts of the United States and are governed by the Bankruptcy Rules promulgated by the U.S. Supreme Court.

In the overwhelming majority of business cases, the failing company (as opposed to a creditor) initiates the bankruptcy process by filing a bank-

trademark owner's consent); Raufast S.A. v. Kicker's Pizzazz, Ltd., 208 U.S.P.Q. 699, 703, 1980 WL 30295 (E.D.N.Y. 1980).

53. Section 1060(a) provides:

(3) Assignments shall be by instruments in writing duly executed. Acknowledgment shall be prima facie evidence of the execution of an assignment, and when the prescribed information reporting the assignment is recorded in the United States Patent and Trademark Office, the record shall be prima facie evidence of execution.

(4) An assignment shall be void against any subsequent purchaser for valuable consideration without notice, unless the prescribed information reporting the assignment is recorded in the United States Patent and Trademark Office within 3 months after the date of the assignment or prior to the subsequent purchase.

(5) The United States Patent and Trademark Office shall maintain a record of information on assignments, in such form as may be prescribed by the Director.

54. See generally H.R. REP. No. 95-595, at 220 (1977), as reprinted in 1978 U.S.C.C.A.N. 5963, 6179-80. 
ruptcy petition with the Bankruptcy Court. ${ }^{55}$ Creditors may, however, force a debtor into bankruptcy. ${ }^{56}$ Filing a petition has two immediate effects. First, it creates a separate legal entity, the "bankruptcy estate," comprising the debtor's assets at the moment of filing, as well as the proceeds of such property and any additional property interests the estate may acquire later. ${ }^{57}$ This estate is managed by the bankruptcy trustee as a fiduciary for the creditors of the insolvent enterprise. ${ }^{58}$ Second, it triggers an "automatic stay" to preserve the bankruptcy estate until all of the debtor's assets can be collected and its creditors brought together to adjudicate their rights in the estate. The automatic stay enjoins creditors from initiating or continuing any action against the debtor or the debtor's property. ${ }^{59}$ The stay protects the debtor from its creditors, subject to the oversight of the bankruptcy judge. After the stay has been entered, any party wishing to proceed against the debtor must obtain authorization from the bankruptcy court. $^{60}$ This rule can have severe ramifications for intellectual property owners. For example, they cannot pursue a breach of contract action or an infringement action without authorization from the bankruptcy judge presiding over the estate.

The bankruptcy system provides two ways for a debtor to discharge its obligations: liquidation (Chapter 7) and reorganization (Chapter 11). ${ }^{61}$ In a Chapter 7 proceeding, the court appoints a trustee to collect the debtor's nonexempt property, sell it all, and equitably distribute the proceeds to the creditors. ${ }^{62}$ Liquidation can be thought of as the "default" bankruptcy proceeding. A Chapter 11 reorganization provides an alternative to Chapter 7 when preserving the company as a going concern would return more value

55. 11 U.S.C. $§ 301$ (2000); see DAVID G. EPSTEIN, STEVE H. NiCKLES \& JAMES J. WHITE, BANKRUPTCY $\S \S 1-7$ (1993).

56. 11 U.S.C. $\S 303(2000)$.

57. 11 U.S.C. $\S 541(a)(2000)$.

58. The bankruptcy trustee is generally a private citizen. The trustee is appointed by a United States Trustee, a government official. When no private trustee can be found, a member of the United States Trustee staff can serve as trustee in a Chapter 7 case. The creditors can elect a trustee to replace an appointed trustee. 11 U.S.C. $\S 702$ (2000). A trustee is not automatically appointed in a Chapter 11 case (absent a selection, the debtor itself acts as trustee), but one may be selected if the court so determines.

59. 11 U.S.C. $\$ 362(2000)$.

60. Section 362(d) authorizes the bankruptcy court to lift the automatic stay when there is a lack of "adequate protection" of a creditor's interest in property. See also 11 U.S.C. $\S 361$ (2000) (making remedies available to afford adequate protection to an interest in property).

61. Intellectual property issues arise most often in the case of business reorganizations under Chapter 11, which will be the focus of this Article.

62. 11 U.S.C. $\S \S 507,701-04(2000)$. 
to the creditors than a fire sale. In Chapter 11, the "debtor in possession" serves as the bankruptcy trustee, with a fiduciary duty to maximize value for the estate's creditors. The debtor retains possession of the company's assets to continue operating the business while developing a plan of reorganization. ${ }^{63}$

The Bankruptcy Code seeks to provide for the equitable distribution of a debtor's assets through equal sharing of losses by creditors of equal rank. ${ }^{64}$ Secured claims - those debts for which the debtor posted and perfected specific collateral as security-take priority over unsecured claims. The posting of collateral creates a property interest in the secured property which cannot be "taken" by the government without the payment of "just compensation." 65 Therefore, security interests must receive the value of their claim that can be satisfied by the collateral (property of the debtor) on which it is secured before any unsecured claimants can share in any value reflected in that collateral. ${ }^{66}$ After all secured claims have been satisfied to the extent covered by collateral, unsecured creditors are entitled to receive payment from the assets remaining. Section 507 of the Bankruptcy Code sets forth nine levels of priority among the unsecured creditors-beginning with administrative expense claims (money spent administering and preserving the estate) and including wage, pension, tax authorities, and other special classes of claimants. Within each class, all members share on a pro rata basis (in proportion to the size of their claim relative to the magnitude of all claims in the class). All senior priority classes must be paid in full before any money can be distributed to lower ranking classes. After priority claims are paid in full, general unsecured creditors share on a pro rata basis in any remaining assets unless a statutory or contractual subordination provision or inequitable conduct compels a different treatment of these claims. ${ }^{67}$

63. 11 U.S.C. $\S \S 1107-08(2000)$.

64. See 11 U.S.C. $\$ 507$ (2000) (establishing claim priorities).

65. U.S. CoNST. amend. V; see In re Gifford, 669 F.2d 468, 471 (7th Cir. 1982), rev'd en banc, 688 F.2d 447 (7th Cir. 1982); Rodrock v. Sec. Indus. Bank, 642 F.2d 1193, 1197-98 (10th Cir. 1981), aff'd, 459 U.S. 70 (1982).

66. Holders of secured claims can be forced to pay for administrative expenses that the court deems to be "reasonable, necessary costs and expenses of preserving, or disposing of, such property to the extent of any benefit to the holder of such claim," if the secured creditor is directly benefited by such expenses. 11 U.S.C. $\S$ 506(c) (2000).

67. 11 U.S.C. $\$ 510(2000)$. Payout rates to general unsecured creditors are typically in the range of thirty to fifty cents on the dollar for reorganized enterprises and five cents on the dollar in liquidations. See Michael J. Herbert \& Domenic E. Pacitti, Down and Out in Richmond, Virginia: The Distribution of Assets in Chapter 7 Proceedings Closed During 1984-87, 22 U. RICH. L. REV. 303, 315, 316 (1988); Lynn M. LoPucki, A General 
In order to avoid the risks of bankruptcy, contracting parties commonly include an "ipso facto" clause in their licensing agreements, which provides for the right of a non-defaulting party to terminate or modify an executory contract upon the insolvency of or filing of a bankruptcy petition by the other party. Derived from the Latin for "by the fact itself," such a clause seeks to resolve the status of the licensing relationship prior to the commencement of the bankruptcy process. To further the policy goal of treating all creditors equally, section 365(e)(1) invalidates any termination or modification clause of an executory contract (or lease) conditioned upon the insolvency or financial condition of a debtor, the filing of a bankruptcy petition, or the appointment of a bankruptcy trustee. ${ }^{68}$

In examining the bankruptcy treatment of intellectual property licenses within the bankruptcy system, it is useful to distinguish between two sets of issues: first, whether intellectual property licenses are characterized as executory contracts (i.e., ongoing contracts) or as sales (i.e., completed transactions); and second, the power of trustees to transfer or rescind executory contracts.

\section{Characterization of Assets}

Assets such as real property or chattels owned by the debtor automatically become part of the bankruptcy estate. Sales of assets completed prior to bankruptcy are outside of the bankruptcy case, and beyond the reach of the bankruptcy court, unless the transaction amounts to a fraudulent transfer. ${ }^{69}$ Most IP licensees fall into a middle ground labeled "executory contracts" that do not automatically enter the bankruptcy estate. Depending on the performance provisions of such contracts, they may constitute net assets or net liabilities of the estate. ${ }^{70}$ In order to promote the maximization of value of the estate and afford the debtor as much flexibility as possible in reorganizing its affairs, the Bankruptcy Code provides the trustee (or "debtor in possession") with the option to "assume" or "reject" executory

Theory of the Dynamics of the State Remedies/Bankruptcy System, 1982 WIS. L. REV. 311, 311 ; Lynn M. LoPucki \& William C. Whitford, Bargaining Over Equity's Share in the Bankruptcy Reorganization of Large, Publicly Held Companies, 139 U. PA. L. REV. 125, 142 (1990).

68. See 11 U.S.C. $\S 365(\mathrm{e})$ (2000). But see F. Scott Kieff \& Troy A. Paredes, An Approach to Intellectual Property, Bankruptcy, and Corporate Control, 82 WASH. U. L.Q. 1313 (2004) (proposing use of special purpose entities for holding IP assets to exclude them from bankruptcy estates).

69. See 11 U.S.C. $\S 548$ (2000). See generally EPSTEIN ET AL., supra note 55, § 6-47.

70. See generally Jesse M. Fried, Executory Contracts and Performance Decisions in Bankruptcy, 46 DUKE L.J. 517 (1996). 
contracts, ${ }^{71}$ subject to some important exceptions that we explore below and to approval by the Bankruptcy Court. ${ }^{72}$

The precise definition of the term "executory" contract is somewhat ambiguous. Although not specifically defined in the Code, the majority of courts have encompassed within this category contracts "on which performance remains due to some extent on both sides," forth by Professor Vern Countryman in the early 1970s (the "Countryman" test). ${ }^{74}$ This test excludes contracts that are already fully performed (or so nearly performed that failure to complete performance would not constitute a material breach) by either party. ${ }^{75}$ Some courts, however, ap-

71. 11 U.S.C. $\S 365$ (a) (2000). In Chapter 7 proceedings, executory contracts that have not been expressly assumed or rejected within 60 days of the filing of a bankruptcy petition are deemed rejected by operation of law. 11 U.S.C. $\S 365(d)(1)(2000)$. In Chapter 11 proceedings, the trustee may assume or reject an executory contract at any time before the confirmation of a plan by the court, although parties to the proceeding may request that the court impose a deadline for decision by the trustee. 11 U.S.C. $\S 365(d)(2)$ (2000).

72. Section 365 , governing the treatment of executory contracts, has been aptly described as "the most convoluted and worst drafted section of the Bankruptcy Code." Daniel J. Bussel \& Edward A. Friedler, The Limits on Assuming and Assigning Executory Contracts, 74 AM. BANKR. L.J. 321, 322 n.6 (2000) (citing NAT'L BANKR. REV. COMM'N, BANKRUPTCY: THE NEXT TWENTY YEARS, FINAL REPORT (1997)); see also Michael T. Andrew, Executory Contracts Revisited: A Reply to Professor Westbrook, 62 U. CoLO. L. REV. 1, 2 (1991) (noting that "behind the deceptively simple prescription of section 365(a) lurks a hopelessly convoluted and contradictory jurisprudence, rendering this one of the most difficult areas of bankruptcy law").

73. H.R. REP. No. 95-595, at 347 (1977), quoted in NLRB v. Bildisco \& Bildisco, 465 U.S. 513, 522 n.6 (1984); see, e.g., Gloria Mfg. Corp. v. Int'l Ladies' Garment Workers' Union, 734 F.2d 1020, 1022 (4th Cir. 1984); Fenix Cattle Co. v. Silver (In re Select-A-Seat Corp.), 625 F.2d 290, 292 (9th Cir. 1980); Cottman Transmissions, Inc. v. Holland Enters., Inc. (In re Holland Enters., Inc.), 25 B.R. 301, 303 (E.D.N.C. 1982); In re A.J. Lane \& Co., Inc., 107 B.R. 435, 436 (Bankr. D. Mass. 1989).

74. Professor Countryman provided a more rigorous definition of "executory contract": "a contract under which the obligations of both the bankrupt and the other party are so far unperformed that failure of either to complete performance would constitute a material breach excusing the performance of the other." Vern Countryman, Executory Contracts in Bankruptcy Law: Part I, 57 MINN. L. Rev. 439, 460 (1973). This test involves an assessment of state law relating to what acts or omissions constitute a material breach.

75. As noted by the court in In re Access Beyond Techs., Inc., 237 B.R. 32 (Bankr. D. Del. 1999) (citing Enter. Energy Corp. v. United States (In re Columbia Gas Sys.), 50 F.3d 233, 240 (3d Cir. 1995)), the test requires a court to determine whether the failure to perform an obligation under the contract would constitute a material breach. 
ply a "functional" test which considers a contract "executory" if the bankrupt estate will benefit from such a classification. ${ }^{76}$

Although IP licensing agreements are not automatically classified as executory contracts, ${ }^{77}$ the courts have readily found that many such agreements satisfy the Countryman test. Specific material performance

76. See Sipes v. Atlantic Gulf Communities Corp. (In re Gen. Dev. Corp.), 84 F.3d 1364, 1374 (11th Cir. 1996) (noting that "courts and commentators have consistently expanded the definition of 'executoriness' beyond the static definition articulated by Professor Countryman" in order to effectuate the language and legislative purposes of section 365 and the Bankruptcy Code); Sloan v. Hicks (In re Becknell \& Crace Coal Co.), 761 F.2d 319, 322 (6th Cir. 1985); Tonry v. Herbert (In re Tonry), 724 F.2d 467, 468 (5th Cir. 1984) (holding a contract to be executory even if only one party has remaining affirmative obligations other than payment of money); Fox v. Hill (In re Fox), 83 B.R. 290, 299 (Bankr. E.D. Pa. 1988); In re Arrow Air, Inc., 60 B.R. 117, 121-22 (Bankr. S.D. Fla. 1986) (noting that the legislative history of section 365 evinces that Congress "considered mutual obligation to be indicative of an executory contract in some, but not all, cases" and that "[e]ven though there may be material obligations outstanding on the part of only one of the parties to the contract, it may nevertheless be deemed executory under the functional approach if its assumption or rejection would ultimately benefit the estate and its creditors"); $c f$. NAT'L BANKR. REV. COMM'N, supra note 72 (recommending deletion of "executory" from the Bankruptcy Code). See generally Jessica L. Kotary \& Nicole L. Inman, Note, Eliminating "Executory" from Section 365: The National Bankruptcy Review Commission's Panacea for an Ailing Statute, 5 AM. BANKR. INST. L. REV. 513 (1997); Jay Lawrence Westbrook, A Functional Analysis of Executory Contracts, 74 MINN. L. REV. 227 (1989).

77. See Perlman v. Catapult Entm't, Inc. (In re Catapult Entm't), 165 F.3d 747, 750 (9th Cir. 1999); In re Qintex Entm't, Inc., 950 F.2d 1492, 1495 (9th Cir. 1991); In re Learning Publ'ns, Inc., 94 B.R. 763, 765 (Bankr. M.D. Fla. 1988); In re Stein \& Day, Inc., 81 B.R. 263, 267 (Bankr. S.D.N.Y. 1988). Some courts, however, presume that intellectual property license agreements are executory without analyzing the nature of the ongoing obligations on both sides of the agreement. See, e.g., RCC Tech. Corp. v. Sunterra Corp., 287 B.R. 864, 865 (D. Md. 2003) (noting without analysis that "there is a long line of authority holding that intellectual property licensing agreements such as the SLA are executory contracts"); In re Buildnet, Inc., 2002 WL 31103235, at *3 (Bankr. M.D.N.C. 2002) (beginning its analysis by asserting that "[a]s a general rule, most patent, trademark, technology and other intellectual property licenses are executory contracts"); In re Golden Books Family Entm't, Inc., 269 B.R. 300, 308-09 (Bankr. D. Del. 2001); Novon Int'l, Inc. v. Novamont S.P.A. (In re Novon Int'l, Inc.), 2000 WL 432848, at *4 (W.D.N.Y. 2000) (confining its analysis to the assertion that "[g]enerally speaking, a license agreement is an executory contract as such is contemplated in the Bankruptcy Code" and attributing that finding to "each party remain[ing] obligated under the agreement-the licensor not to sue for infringement and the licensee to use the patent in accordance with the terms of the agreement"); In re Patient Educ. Media, Inc., 210 B.R. 237, 241 (Bankr. S.D.N.Y. 1997). Nonetheless, the Bankruptcy Code does not place "intellectual property" licenses in any special class with regard to the determination of whether they are executory. Each case requires the application of either the Countryman or functional test (depending upon the circuit) to the case-specific factors. 
obligations, such as a continuing obligation to account for and pay royalties, duties of notice, ${ }^{78}$ responsibilities relating to reporting, labeling, policing, service, and maintenance, refraining from licensing to others (in the context of an exclusive licensing agreement), ${ }^{79}$ and obligations to provide product upgrades, potentially bring one or the other of the parties' activities within the domain of executory contracts. An agreement is not executory, however, simply because one party is obligated to make payments of money to the other party. ${ }^{80}$ Furthermore, some agreements might not clear the executory hurdle because failure to perform the outstanding obligations by one of the parties would not constitute a material breach of the contract. ${ }^{81}$ They might also fail where clauses are mere conditions that, if not adhered to, would relieve the other contracting party of continuing performance, but would not amount to breach of the contract. ${ }^{82} \mathrm{~A}$ critical issue in understanding the meaning of "executory" in the context of intellectual property licensing agreements is whether the licensor's "duty" to forbear from suing the licensee for infringement represents an independent obligation that can support the licensor's responsibilities being deemed executory. Several courts have so held, ${ }^{83}$ but careful examination of the nature of intellectual property rights suggests otherwise. ${ }^{84}$ We take this issue up in detail below.

Numerous cases have examined whether intellectual property agreements constitute executory agreements or outright transfers of intellectual property rights. As a means of surveying the range of cases, we first explore those cases that have found intellectual property agreements to be sales or assignments rather than executory contracts. We then divide the

78. See Lubrizol Enters., Inc. v. Richmond Metal Finishers, Inc., 756 F.2d 1043, 1045 (4th Cir. 1985).

79. See Fenix Cattle Co. v. Silver (In re Select-A-Seat Corp.), 625 F.2d 290, 292 (9th Cir. 1980).

80. See Lubrizol, 756 F.2d at 1046.

81. See, e.g., Gencor Indus., Inc. v. CMI Terex Corp. (In re Gencor Indus., Inc.), 298 B.R. 902 (Bankr. M.D. Fla. 2003) (finding that the obligation of confidentiality was for the unilateral benefit of only one party and that breach of that obligation would not cause a material breach of the overall agreement).

82. Id. (finding that the Most Favored Nations Clause and the Patent Defense Clause of a licensing agreement were mere conditions of payment by the licensee (failure of which would excuse further payment) rather than material continuing obligations (failure of which would breach the contract)).

83. See Everex Sys., Inc. v. Cadtrak Corp. (In re CFLC, Inc.), 89 F.3d 673, 673 (9th Cir. 1996); In re Novon Int'l, 2000 WL 432848 (W.D.N.Y. 2000); In re Golden Books Family Entm't, Inc., 269 B.R. 300, 309 (Bankr. D. Del. 2001); In re Access Beyond Techs., Inc., 237 B.R. 32, 43 (Bankr. D. Del. 1999).

84. See In re Gencor Indus., 298 B.R. at 902. 
cases into the various categories of intellectual property rights to explore what obligations in a license agreement make a contract executory.

a) Sales, Assignments, and Exclusive Licenses of Intellectual Property Rights

A completed sale or assignment of intellectual property rights without further non-severable contractual obligations is not considered "executory." Unfortunately, the "cases are far from clear as to what is a sale, assignment, or outright transfer (or how a court distinguishes between them)."

A logical starting point is to look at how the intellectual property statutes govern transfers of rights. The Patent Act states that "patents shall have the attributes of personal property" and "shall be assignable in law by an instrument in writing." ${ }^{86}$ It states further that the patentee (or his assigns) may "grant and convey an exclusive right" under his patent "to the whole or any specified part of the United States." An agreement is a sale (or assignment) of patent rights only if it conveys: "1. the whole patent, comprising the exclusive right to make, use and sell the invention; 2 . an undivided share of that exclusive right; or 3 . an exclusive right to practice the invention within a specified territory." provides that " $[t]$ he ownership of a copyright may be transferred in whole or in part by any means of conveyance ....,88

An assignment of intellectual property rights constitutes a transfer of the rights and therefore is fully executed upon completion of the transaction. Thus, the court in Chesapeake Fiber Packaging Corp. v. Sebro Packaging Corp. ${ }^{89}$ held that an agreement stating that "[patent holder] hereby sells, assigns, transfers and sets over to [alienee] its entire right, title and interest in, to, and under the aforesaid Invention(s) and any and all Letters Patent ..." amounted to an outright grant of transfer of the intel-

85. David I. Cisar, Exclusive and Nonexclusive IP Licenses and Executory Contract Assumption and Assignment: Does Exclusivity Matter?, 22 AM. BANKR. INST. J. 28, 28 (Feb. 2003).

86. 35 U.S.C. $\S 261(2000)$.

87. In re Access Beyond Techs., Inc., 237 B.R. 32, 44 (Bankr. D. Del. 1999) (citing Waterman v. Mackenzie, 138 U.S. 252, 255-56 (1891)); see Wing v. Comm'r, 278 F.2d 656,661 (8th Cir. 1960) ("[E]xclusive licenses to manufacture, use, and sell for the life of the patent, are considered to be 'sales or exchanges' because, in substantive effect, all 'right, title, and interests' in the patent property is transferred . ....'); see also Ortho Pharm. Corp. v. Genetics Inst., Inc., 52 F.3d 1026, 1032 (Fed. Cir. 1995) (recognizing exclusive licensee's right to sue under patent law).

88. 17 U.S.C. $\S 201(d)(1)(2000)$.

89. 143 B.R. 360,363 (Bankr. D. Md. 1992), aff'd, 8 F.3d 817 (4th Cir. 1993). 
lectual property rights, even though the assignee had a continuing obligation to make royalty payments. ${ }^{90}$

Outright sales of products (including those granting nonexclusive licenses to use the intellectual property embodied in the products) are not executory. For example, a mass-marketed computer software product distributed in conjunction with a "shrink wrap" end user license agreement ${ }^{91}$ granting the user nonexclusive rights to use the software is generally not considered executory because only the licensee has any remaining obligations under the purported agreement. ${ }^{92}$

In a more complex bilateral licensing context, the Ninth Circuit in In re DAK Indus., Inc. treated an agreement authorizing a licensee to load copyrighted software onto computer systems as a sale rather than an executory contract. ${ }^{93}$ Microsoft and DAK Industries, Inc., entered into a "License Agreement" granting DAK nonexclusive, worldwide license rights to distribute Microsoft's Word for Windows software program on its computer systems. In exchange, DAK agreed to pay a minimum contract fee of $\$ 2,750,000$ in five installments and a royalty rate of $\$ 55$ per unit for any number of computers sold with the Microsoft software beyond the first 50,000 units. Focusing on what it called the "economic realities" of the agreement, the Ninth Circuit concluded that the minimum commitment contract in question was "best characterized as a lump sum sale of software units to DAK, rather than a grant of permission to use an intellectual property" 94 based on the following considerations: (1) the pricing and timing of the payments were more consistent with a sale than a lease or license-DAK agreed to pay $\$ 2,750,000$ at the outset of the agreement regardless of how many units it sold; (2) the licensee received all of its rights at the beginning of the agreement; (3) the agreement did not simply permit the debtor to use the technology, but also permitted the debtor to sell the technology; and (4) Microsoft delivered the master disk from which the copies were to be made at the time the agreement commenced

90. Cf. Conde Nast Publ'ns, Inc. v. United States, 575 F.2d 400 (2d Cir. 1978) (holding exclusive trademark and trade name license considered a "sale" for tax treatment purposes and restriction on assignability not inconsistent with a completed sale).

91. A shrinkwrap end user licensing agreement is a license agreement, contained in a plastic wrapping or other packaging surrounding computer software or other media, that states that by opening the packaging, the consumer agrees to the conditions set forth.

92. See Raymond T. Nimmer, Information Law § 11:161 (2006).

93. Microsoft Corp. v. DAK Indus., Inc. (In re DAK Indus., Inc.), 66 F.3d 1091, 1095-96 (9th Cir. 1995).

94. Id. at 1095. 
and therefore had substantially completed its performance at the outset of the contract. ${ }^{95}$

The fact that an IP agreement grants exclusive rights to the licensee cuts in favor of the transaction being characterized as a transfer because it represents a more complete conveyance of rights than a nonexclusive license and may have fewer strings (contractual obligations) attached. ${ }^{96}$ However, it may still be characterized as an executory contract if both parties have significant ongoing duties connected to the license of intellectual property rights. ${ }^{97}$ By contrast, a nonexclusive license typically grants a licensee permission to use certain intellectual property - a personal right, but no ownership interest in the intellectual property. ${ }^{98}$ The licensor re-

95. Id. at $1095-96$.

96. Section 101 of the Copyright Act defines a "transfer of copyright ownership" to include an "exclusive license." $C f$. Fawick v. Comm'r, 436 F.2d 655, 662 (6th Cir. 1971) (noting that exclusive license agreements in some instances may constitute a sale for tax purposes). There is some confusion among the courts over the extent to which the granting of an exclusive license constitutes a full transfer of rights. Compare I.A.E., Inc. v. Shaver, 74 F.3d 768, 774-75 (7th Cir. 1996) (holding that the licensee under an exclusive license may freely transfer his rights), with Gardner v. Nike, Inc., 279 F.3d 774, 780 (9th Cir. 2002) (reaching contrary result). See also In re Hernandez, 285 B.R. 435 (Bankr. D. Ariz. 2002) (holding that the granting of an exclusive patent license did not afford the licensee the right to assign the patent).

97. The cases do not explain what "extra" duties exist to bring these agreements within the ambit of "executory contracts." For example, in University of Connecticut Research \& Development Corp. v. Germain (In re Biopolymers, Inc.), 136 B.R. 28 (Bankr. D. Conn. 1992), the licensor granted an exclusive license (subject to the government's "march-in" rights for publicly funded innovation under the Bayh-Dole Act, 35 U.S.C. $\S 203$ (2000 \& Supp. 2003)) "to make, use and sell" products for the life of the patent, and to grant sublicenses to third parties, subject to the approval of the licensor not to be unreasonably withheld. In exchange, the licensee agreed to make an initial cash and stock payment and to pay defined royalties, provide quarterly business reports, and use its best efforts to produce and sell the products. The court found this agreement to be executory on both sides, although the licensor's obligations amounted solely to using reasonable standards for approving third party licensees that the licensee brought forward. In another case, the agreement at issue granted an exclusive license but only as to a subset of possible uses. The court concluded that the agreement did not rise to the level of an assignment or sale of the intellectual property at issue, implicitly finding the agreement to be executory. See In re Supernatural Foods, L.L.C., 268 B.R. 759 (Bankr. M.D. La. 2001).

98. "Unless the writing conveys some or all of the right to exclude others from practicing the invention, it will not convey an interest in the patent, but is a mere license." In re Access Beyond Techs., Inc. 237 B.R. 32, 44 (Bankr. D. Del. 1999) (citing Waterman v. Mackenzie, 138 U.S. 252, 255-56 (1891)); see also Madlyn G. Primoff \& Erica G. Weinberger, E-Commerce and Dot-Com Bankruptcies: Assumption, Assignment, and Rejection of Executory Contracts, Including Intellectual Property Agreements, and Related Issues under Sections 365(c), 365(e) and 365(n) of the Bankruptcy Code, 8 AM. BANKR. INST. L. REV. 307 (2000). 
tains the rights and remedies associated with the intellectual property, and therefore no transfer of property occurs. Even where a licensor grants an exclusive license, however, the agreement may provide for ongoing, reciprocal, non-severable ${ }^{99}$ duties that could conceivably bring the agreement into the realm of executory contracts. Moreover, several courts find that exclusive licenses inherently impose executory obligations upon licensors because they oblige the licensor to refrain from extending further licenses (or selling the product in the exclusive territory themselves). ${ }^{100}$

b) The Classification of Mode-Specific IP Licenses

\section{i) Patent Licenses}

In the context of patent licenses, courts consider a wide range of continuing contractual obligations to place such agreements in the category of executory contracts. With regard to licensees, an ongoing obligation to account for and pay royalties for the life of the agreement meets the Countryman test for an executory contract. ${ }^{101}$ Other material ongoing licensee obligations such as sharing of technology with the licensor, reporting on problems with the technology, and marking all products sold under the license with proper statutory patent notice ${ }^{102}$ would likely be deemed material and support a finding that the licensee side of the agreement is executory. Turning to licensors, courts have held the following obligations sufficient to bring the licensor's side of the transaction into the executory classification: providing a nonexclusive licensee notice of any patent infringement suit or any other use or licensing of the process, ${ }^{103}$ refraining from licensing the technology to anyone else at a lower royalty rate (a Most Favored Nation clause), ${ }^{104}$ approving grants of sublicenses under

99. Cf. Stewart Title Guar. Co. v. Old Republic Nat'l Title Ins. Co., 83 F.3d 735 (5th Cir. 1996) (holding that a license to use certain copyrighted designs in the event an agreement was terminated was a vested (non-executory) right provided to the licensee and was severable from an executory lease provision of the agreement).

100. Fenix Cattle Co. v. Silver (In re Select-A-Seat Corp.), 625 F.2d 290, 292 (9th Cir. 1980); In re HQ Global Holdings, Inc., 290 B.R. 507, 510-1 1 (Bankr. D. Del. 2003) (finding that a licensor which granted an exclusive territorial license bore a continuing material obligation not to engage in business in that territory).

101. See Lubrizol Enters., Inc. v. Richmond Metal Finishers, Inc., 756 F.2d 1043, 1045 (4th Cir. 1985).

102. Everex Sys., Inc. v. Cadtrak Corp. (In re CFLC, Inc.), 89 F.3d 673, 677 (9th Cir. 1996) (noting because failure to mark deprives the patent holder of damages in an infringement action, the licensee's performance of this duty is material).

103. See Lubrizol, 756 F.2d at 1045-46.

104. Id. 
reasonable standards, ${ }^{105}$ indemnifying licensees for losses, ${ }^{106}$ and defending claims of infringement. ${ }^{107}$

There is controversy over whether a licensor's forbearance from suing a licensee for infringement throughout the duration of the agreement represents in and of itself a material ongoing executory obligation. In Everex Systems, Inc. v. Cadtrak Corp. (In re CFLC, Inc.), ${ }^{108}$ the Ninth Circuit held that a licensor's obligation to refrain from suing a nonexclusive licensee cleared the executory hurdle because "a nonexclusive patent license is, in essence 'a mere waiver of the right to sue' the licensee for infringement." 109 Such a rationale, however, is tautological. By licensing the patent to the licensee, the licensor gives up the right to sue the licensee for infringement. The license itself represents a covenant not to sue ${ }^{110}$ and consequently a continuing obligation not to sue the licensee would appear to be an empty duty. The license itself is a complete defense to the claim. Therefore, this "obligation," standing alone, should not be deemed sufficient to make the licensor's side of the agreement executory.

\section{ii) Copyright Licenses}

Copyright licenses vary in their obligations. At one end of the spectrum, an author (or other copyright owner) licenses a completed copyrighted work to a publisher in exchange for either a lump sum payment or an ongoing royalty stream. In this circumstance, the licensor's obligations are complete upon delivery of the work and therefore there is nothing to be executed on that end of the agreement. The licensee may well have material ongoing obligations - such as publishing and distributing the work and paying and accounting for royalties-which would be considered executory in nature. Since both sides of the agreement must be executory,

105. See Univ. of Conn. Research \& Dev. Corp. v. Germain (In re Biopolymers, Inc.), 136 B.R. 28, 30 (Bankr. D. Conn. 1992).

106. See Lubrizol, 756 F.2d at 1043.

107. See Biosafe Int'l, Inc. v. Controlled Shredders, Inc. (In re Szombathy), $1996 \mathrm{WL}$ 417121 (Bankr. N.D. Ill. 1996), rev'd in part on other grounds, Szombathy v. Controlled Shredders, Inc., 1997 WL 189314 (N.D. Ill. 1997).

108. 89 F.3d 673 (9th Cir. 1996).

109. Id. at 677; see also In re Access Beyond Techs., Inc. 237 B.R. 32, 43 (Bankr. D. Del. 1999) (citing the minimal Everex standard with approval while also noting that the license agreement in its case imposed ongoing duties upon each party to provide the other with sub-licenses); Novon Int'l, Inc. v. Novamont S.P.A. (In re Novon Int'l, Inc.), 2000 WL 432848 (W.D.N.Y. 2000).

110. Gencor Indus., Inc. v. CMI Terex Corp. (In re Gencor Indus., Inc.), 298 B.R. 902, 912 (Bankr. M.D. Fla. 2003). 
such a contract would fall outside of the class of executory contracts under the Countryman test. ${ }^{111}$ The licensor is merely a creditor.

At the other end of the spectrum, some copyright licenses arise in a context in which a work has yet to be created, or will be edited, revised, or otherwise adapted. Where such efforts are still ongoing, or planned for the future, at the time of the bankruptcy filing, there will likely be material continuing obligations on the side of the creative artist. Where the other party has ongoing commercialization obligations, such as distributing the completed work and accounting for and paying royalties, or where creative responsibility lies on both sides of the agreement, the agreement will satisfy the Countryman test. ${ }^{112}$ For example, in In re Qintex Entertain$m e n t,{ }^{113}$ the licensee agreed to pay a fixed sum plus a percentage of gross receipts to the owner of several films in return for the rights to colorize and distribute the films for twenty-four years. The licensee was required to indemnify and defend the licensee in the event of litigation and to exercise creative control over the colorization and marketing of the films. ${ }^{114}$ The Ninth Circuit found the agreement to be executory. ${ }^{115}$ Similarly, record

111. See, e.g., Official Unsecured Creditors' Comm. v. Zenith Prods., Ltd. (In re AEG Acquisition Corp.), 127 B.R. 34 (Bankr. C.D. Cal. 1991), aff'd, 161 B.R. 50 (B.A.P. 9th Cir. 1993) (involving a contract for transfer of films not executory); In re Learning Publ'ns, Inc., 94 B.R. 763, 765 (Bankr. M.D. Fla. 1988) (involving a book contract in which authors had performed their contractual obligations by the time of the bankruptcy filing); In re Stein \& Day, Inc., 81 B.R. 263, 267 (Bankr. S.D.N.Y. 1988) (same). As noted by a commentator and quoted in In re AEG Acquisition, 161 B.R. at 59-60:

Copyright assignments and licenses should not be treated as executory contracts .... According to the Copyright Act, assignments and licenses are transfers of copyright ownership; bankruptcy courts should treat them that way. If a debtor has granted an assignment or exclusive license of its copyright rights prior to filing bankruptcy, the assignment or exclusive license should be treated as a completed prebankruptcy transfer of property by the debtor, not as an executory contract .... Conversely, if a debtor enters bankruptcy with valid copyright assignments or exclusive licenses of copyright rights owned by others, those assignments or exclusive licenses are property of the estate, not executory contracts.

J. Brinson, The Copyright Act and Bankruptcy: Perfection, Priorities, and Transfers, $1 \mathrm{~J}$. BANKR. L. \& PRACT. 337, 353 (1992) (footnotes omitted).

112. See, e.g., Viacom Latino Americana, Inc. v. Three Star Corp. (In re Three Star Telecast, Inc.), 93 B.R. 310,312 (D.P.R. 1988) (involving a television program licensing agreement where programs were not yet completed).

113. 950 F.2d 1492, 1494-95 (9th Cir. 1991).

114. Id. at 1493-94.

115. Id. at 1495. The court's decision rests on a strong foundation in view of the material ongoing responsibilities involved. The court may confuse the analysis, however, by counting among the duties of the licensor the obligation "to refrain from selling the rights 
contracts between recording artists and record labels typically have extensive continuing obligations upon both sides of the agreement and hence fall within the domain of executory contracts. ${ }^{116}$

iii) Trade Secret Licenses

Trade secret licenses often arise in the context of extensive ongoing interaction between contracting parties. Furthermore, such licenses, by their nature, impose particular material obligations upon the parties, such as confidentiality requirements and the exercise of reasonable precautions to maintain trade secrecy. Therefore, such agreements are likely to clear the executory threshold. ${ }^{117}$

\section{iv) Trademark Licenses}

Trademark licenses are almost always executory because the licensor has continuing quality control obligations and the licensee typically has payment, reporting, marketing, and other continuing performance obligations. ${ }^{118}$ Licensors may also have duties to notify the licensee of any in-

to subdistribute the movies." As noted above, see supra note 110 , refraining from licensing to others that which was reserved to the licensee is not a separate obligation but merely an inherent covenant of the licensing agreement. In Qintex, the licensor had granted an exclusive license and therefore should not be credited with an affirmative obligation not to license the same rights to others. See also In re Golden Books Family Entm't, Inc., 269 B.R. 300, 308-09 (Bankr. D. Del. 2001) (concluding that copyright and trademark licenses to various cartoon characters were executory based solely on each party's presumed "material duty" of "refraining from suing the other for infringement of any of the [intellectual property] covered by the license" (quoting In re Access Beyond Techs., Inc. 237 B.R. 32, 43 (Bankr. D. Del. 1999)).

116. See Cloyd v. GRP Records (In re Cloyd), 238 B.R. 328, 335 (Bankr. E.D. Mich. 1999); In re Taylor, 103 B.R. 511, 516 (D.N.J. 1989), aff'd in part and appeal dismissed in part, 913 F.2d 102 (3d Cir. 1990); In re Noonan, 17 B.R. 793, 798 (Bankr. S.D.N.Y. 1982) (stating recording contract is not asset that can be used for its estate's benefit); Kotary \& Inman, supra note 76, at 522-29. See generally Jennifer A. Brewer, Bankruptcy \& Entertainment Law: The Controversial Rejection of Recording Contracts, 11 AM. BANKR. INST. L. REV. 581 (2003). A recording contract is not executory, however, where the parties have terminated the artist's continuing performance obligations and the record company's only remaining obligation is to pay royalties to the recording artist-licensor. See In re Monument Record Corp., 61 B.R. 866, 866 (Bankr. M.D. Tenn. 1986).

117. Few reported cases squarely address the question of whether a trade secret agreement is executory. In In re Matusalem, 158 B.R. 514, 515 (Bankr. S.D. Fla. 1993), the court presumes that a license for a secret formula for making rum, as well as an associated trademark, is executory without explaining the basis.

118. See, e.g., In re HQ Global Holdings, Inc., 290 B.R. 507, 509 (Bankr. D. Del. 2003); Blackstone Potato Chip Co., Inc. v. Mr. Popper, Inc. (In re Blackstone Potato Chip Co., Inc.), 109 B.R. 557, 560 (Bankr. D.R.I. 1990); Richard Royce Collection, Ltd. v. N.Y. City Shoes, Inc. (In re N.Y. City Shoes, Inc.), 84 B.R. 947, 951 (Bankr. E.D. Pa. 
fringements of the licensed trademarks, to enforce the trademark for the benefit of the licensee, and to indemnify the licensee for any damages, expenses, and attorneys' fees. ${ }^{119}$ Franchise agreements commonly include trademark licenses and easily clear the executory hurdle in both directions due to the many ongoing obligations of the contracting parties. ${ }^{120}$

\section{v) Software License Agreements}

With the growth of computer technology, computer software licensing has become a vibrant marketplace. These types of agreements typically embody several modes of intellectual property. It is useful to distinguish between business-to-business software agreements-custom and semicustomized programs for large-scale computers and networks as well as licenses between software developers and computer manufacturers, websites, and other businesses that distribute software-and business-toconsumer licensing agreements.

In the mainframe and minicomputer sectors of the market, many software companies provide software on a customized basis with significant ongoing responsibilities. These companies typically use sophisticated licensing agreements that involve ongoing obligations-including service, support, and upgrades. The licensees are typically bound by ongoing confidentiality, trade secret, use, and copying restrictions as well as reporting and payment schedules. Therefore, these sorts of relationships easily clear the executory threshold. ${ }^{121}$

In the microcomputer marketplace, software vendors distribute their products through several marketing channels. It is common for computer manufacturers to pre-install several software products on their machines at the factory. Microsoft and other leading software vendors typically provide these original equipment manufacturers (OEMs) with a master disk

1988); In re Specialty Foods Pittsburgh, Inc., 91 B.R. 364, 374 (Bankr. W.D. Pa. 1988); In re Chipwich, Inc., 54 B.R. 427, 429 (Bankr. S.D.N.Y. 1985).

119. See In re Chipwich, 54 B.R. at 429.

120. See, e.g., Silk Plants, Etc. Franchise Sys., Inc. v. Register (In re Silk Plants, Etc. Franchise Sys., Inc.), 100 B.R. 360, 361-62 (M.D. Tenn. 1989); JRT, Inc. v. TCBY Sys. Inc. (In re JRT, Inc.), 121 B.R. 314, 320 (Bankr. W.D. Mich. 1990); Elec. Realty Assocs., Inc. v. ERA Cent. Reg'l Servs., Inc. (In re ERA Cent. Reg'l Servs., Inc.), 39 B.R. 738, 739 (Bankr. C.D. Ill. 1984).

121. See In re Sunterra Corp., 361 F.3d 257, 264 (4th Cir. 2004) ("When the bankruptcy petition was filed, each party owed at least one continuing material duty to the other under the Agreement-they each possessed an ongoing obligation to maintain the confidentiality of the source code of the software developed by the other, i.e., the Software and the Sunterra Enhancements."); In re Kmart Corp., 290 B.R. 614, 617-19 (Bankr. N.D. Ill. 2003). 
from which they make copies for each computer system that they sell. These agreements commonly license copyright, trademark, trade secret, and patent rights and may impose service, upgrade, and other obligations on the licensor. The licensee must maintain any trade secrets and account for and pay royalties based on the number of units sold. These licensing relationships generally fall within the executory domain. ${ }^{122}$ Where the licensor grants an exclusive territorial or field license, some courts consider the licensor's implied obligation to refrain from licensing or selling to others to be enough to make the license executory. ${ }^{123}$ But where the terms and duties of the agreement have the attributes of a sale (i.e., lump sum amount irrespective of the number of units distributed) in which the licensor bears little or no continuing obligations, then the agreement may be treated as non-executory. ${ }^{124}$

Business-to-consumer software licensing agreements have a very different motivation and purpose than the licensing contexts discussed above. Both software pre-loaded onto computer systems and software packages distributed through retail outlets attempt to bind consumers to an "end user licensing agreement" (EULA). This contracting form evolved as a means for augmenting or contracting around various default rules of intellectual property law. For example, by "licensing" the software to consumers, software vendors attempt to avoid the effects of the first sale doctrine of copyright and patent law. In addition, some EULAs prohibit reverse engineering of software products, ${ }^{125}$ which is generally permissible under copyright law. ${ }^{126}$

From the standpoint of the Bankruptcy Code, EULA transactions generally fall within the category of a completed sale. The end user makes a one-time payment and receives the software product. Although the end user may have ongoing responsibilities under license based on the restrictions in the license, ${ }^{127}$ the licensor generally does not have ongoing responsibilities.

122. See, e.g., In re Logical Software, Inc., 66 B.R. 683, 686 (Bankr. D. Mass. 1986) (indicating no dispute as to the executory nature of agreement).

123. See, e.g., Fenix Cattle Co. v. Silver (In re Select-A-Seat Corp.), 625 F.2d 290, 291-92 (9th Cir. 1980).

124. See Microsoft Corp. v. DAK Indus., Inc. (In re DAK Indus., Inc.), 66 F.3d 1091, 1095-96 (9th Cir. 1995).

125. See Bowers v. Baystate Techs., Inc., 320 F.3d 1317, 1323-24 (Fed. Cir. 2003).

126. See Sega Enters. Ltd. v. Accolade, Inc., 977 F.2d 1510, 1527-28 (9th Cir. 1992).

127. See, e.g., ProCD, Inc. v. Zeidenberg, 86 F.3d 1447 (7th Cir. 1996). 


\section{Resolution of the Bankrupt Estate: Dishonoring of Contract}

As discussed, the Chapter 11 debtor must arrange the estate to maximize value for creditors. If a contract is held to be executory, the debtor has three options: (1) assumption of the contractual obligations; (2) rejection of the contract; or (3) assignment (or transfer) of the contract.

\section{a) Assumption}

Most assumptions of contracts are approved without objection. The bankruptcy court applies a relatively liberal "business judgment" standard in assessing any disputes over assumptions and rejections of contracts by the debtor. ${ }^{128}$ Upon the court's approval of the debtor's assumption of an executory contract, the pre-petition contract is reinstated and becomes fully binding. The debtor cannot assume a contract, however, without first meeting the statutory preconditions of curing outstanding defaults under the contract (or providing "adequate assurance" that it will do so). ${ }^{129}$ In addition, the debtor must "provide adequate assurance of future performance." 130 Upon assumption, the contractual obligations become those of the estate and any contract by the debtor after such time will likely result in a post-petition damages claim for breach of contract (treated as a first priority administrative claim, ${ }^{131}$ usually at 100 cents on the dollar) rather than a pre-petition claim for damages (which is payable only as set forth in the plan of reorganization).

b) Rejection

Bankruptcy courts similarly apply the deferential business judgment rule in reviewing rejections of executory contracts. ${ }^{132}$ Where the court approves a debtor's rejection of an executory contract, section $365(\mathrm{~g})$ of the Code provides that the debtor is deemed to have breached the agreement, giving rise to a pre-petition damages claim for breach of contract. That

128. See Johnson v. Fairco Corp. (In re Johnson), 61 B.R. 317, 320 (Bankr. N.D. Ill. 1986) (describing the business judgment standard as a "lax standard" that disturbs a debtor's actions "[o]nly where [such actions] are in bad faith or in gross abuse of its managerial discretion").

129. See 11 U.S.C. $\S 365(\mathrm{~b})(1)(\mathrm{B})$ (2000). The debtor must also make whole any third parties who suffered losses as a result of the defaults.

130. See 11 U.S.C. $\S 365(b)(1)(C)(2000)$.

131. 11 U.S.C. $\S \S 503,507(\mathrm{a})(1)(2000)$.

132. Although the business judgment standard of review is highly deferential, a bankruptcy tribunal may, as a court of equity, restrain a debtor's rejection of a contract where such an action will needlessly inflict great damage on the licensee, especially if not accompanied by some countervailing benefit to the estate. See In re Petur U.S.A. Instrument Co., 35 B.R. 561, 563 (Bankr. W.D. Wash. 1983). 
damages claim, if allowed by the bankruptcy court, is a general unsecured claim, placing the breached party's claim among the pool of general unsecured claims. The Bankruptcy Code bars the remedy of specific performance for a rejected executory contract.

\section{c) Assignment}

Once a debtor assumes an executory contract, it may seek to assign that contract to a third party. Bankruptcy law generally authorizes the assignment of executory contracts so as to afford the bankrupt estate the greatest flexibility in reorganizing its business and obtaining value for its creditors, even where the agreement expressly prohibits assignment. ${ }^{133}$ The Code provides several exceptions and limitations on the assignment of contracts. ${ }^{134}$ Of greatest significance to IP license agreements, section $365(\mathrm{c})(1)$ prohibits the assignment of an executory contract where "[a]pplicable law excuses a party, other than the debtor, to such contract ... from accepting performance from or rendering performance to an entity other than the debtor or the debtor in possession, whether or not such contract ... prohibits or restricts assignment of rights or delegation of duties" and "[s]uch party does not consent to such assumption or assignment." For example, general contract law principles prohibit the assignment of personal service contracts without the promisor's consent. Thus, under section 365(c)(1), an agreement whereby Tony Bennett would perform at a particular arena on a particular night could not be assigned to another promoter or venue without Mr. Bennett's consent.

\section{Summary}

It is easy to see how the core policies of the intellectual property laws and the bankruptcy system can conflict in action. In a Chapter 11 reorganization, the Bankruptcy Code focuses upon rehabilitating the debtor and providing it with a "fresh start." If the failing enterprise is the licensor of intellectual property, the trustee might seek to rescind licenses in an effort to negotiate better terms. By that point in time, the licensee may have made substantial specific investments in reliance on the continued licensing of intellectual property rights. In a Chapter 7 liquidation, the trustee of the debtor's estate seeks to sell off the assets to the highest bidder. Where the failing enterprise is a licensee of intellectual property, such licenses are

133. Section $365(f)(1)$ provides that an executory contract may be assigned after it is assumed even though the contract, lease, or applicable law provides otherwise, except as provided in subsection (c) of this section. See also 11 U.S.C. $\S 365(f)(2)$ (1994) (stating conditions necessary to be satisfied before executory contracts may be assigned); In re Wash. Capital Aviation \& Leasing, 156 B.R. 167, 175 (Bankr. E.D. Va. 1993).

134. 11 U.S.C. $\S 365$ (c) $(2000)$. 
placed on the auction block and potentially purchased by entities that could undermine the business strategy of the IP owner-such as unreliable enterprises, or worse, competitors that seek to drive the licensor from the market. From an ex ante perspective, both of these possibilities create risks that reduce the expected value of intellectual property transactions. The inability to contract around this risk (due to the unenforceability of ipso facto clauses) could squelch an otherwise promising transaction or reduce the license-specific investments that would maximize the value of intellectual property licenses. As the following sections explore, bankruptcy law has evolved to ameliorate such concerns, but complexities and problems remain.

\section{THE LICENSOR BANKRUPTCY PROBLEM}

The risk of bankruptcy can undermine the incentives for parties to license intellectual property and make optimal investments in exploiting those licenses that are consummated. When a licensor of intellectual property rights enters bankruptcy, the Bankruptcy Code's generally permissive attitude toward a debtor's rejection of executory contracts can lead to particularly harsh results for licensees who have built a business or product line upon use of the licensor's intellectual property. As noted above, provisions that contract around the Bankruptcy Code are generally unenforceable, severely limiting licensees' ability to prevent such hardship. ${ }^{135}$ The licensee loses continued use of the licensed intellectual property and is left with a pre-petition claim for contract damages. Due to the exclusivity of intellectual property rights, the licensee cannot go elsewhere to obtain the rights needed to continue its operations built upon such assets.

A 1985 Fourth Circuit decision, Lubrizol Enterprises, Inc. v. Richmond Metal Finishers, Inc. ${ }^{136}$ called attention to this problem. In Lubrizol, the debtor, Richmond Metal Finishers (RMF), had granted Lubrizol Enterprises a nonexclusive license to use its patented metal coating process. When RMF entered bankruptcy, it proposed to the bankruptcy court, as part of its reorganization plan, to reject the contract with Lubrizol in order to facilitate sale or licensing of the technology. After determining that the technology licensing agreement was an executory contract, the court approved rejection under the business judgment rule. The court found no evidence to suggest that the debtor's decision was taken in bad faith or reflected a gross abuse of business discretion. The court acknowledged, however, that allowing rejection of such contracts "imposes serious bur-

135. See supra text accompanying note 67 (discussion of section $365(\mathrm{e})(1)$ ).

136. 756 F.2d 1043 (4th Cir. 1985). 
dens upon contracting parties [and] could have a general chilling effect upon the willingness of [potential IP licensees] to contract at all with businesses in possible financial difficulty." 137 Nonetheless, the court concluded that addressing these concerns was beyond its authority and rested with the Congress.

The Lubrizol decision produced a strong adverse reaction within the intellectual property, high technology, and investor communities. The protection and ability to make continued use of intellectual property is critical to the formation of many new technology-oriented businesses. In a letter to the Senate Judiciary Committee concerning this issue, the U.S. Department of Commerce complained that the risk of IP licenses being rejected by debtor-licensors would

exacerbate the plight of independent inventors, small businesses, and entrepreneurs in high risk areas, who are often without adequate resources and for whom the availability of risk capital is already a major problem. Even for established enterprises, the financial stability of the licensing partner may introduce unacceptable levels of risk and preclude significant investment in technology that must be acquired by license. ${ }^{138}$

Heeding these admonitions, Congress carved out a special exception to the general bankruptcy law standards applicable to IP licensees for rejecting executory contracts. ${ }^{139}$ The Intellectual Property Bankruptcy Protection Act of 1988 (IPBPA) added the following provision to section 365:

(n)(1) If the trustee rejects an executory contract under which the debtor is a licensor of a right to intellectual property, the licensee under such contract may elect-

(A) to treat such contract as terminated by such rejection if such rejection by the trustee amounts to such a breach as would entitle the licensee to treat such contract as terminated by virtue of its own terms, applicable nonbankruptcy law, or an agreement made by the licensee with another entity; or (B) to retain its rights (including a right to enforce any exclusivity provision of such contract, but excluding any other

137. Lubrizol, 756 F.2d at 1048.

138. S. REP. NO. 100-505 (1988), as reprinted in 1988 U.S.C.C.A.N. 3200.

139. The purpose of this exception was to encourage investment in intellectual property and to protect the right of licensees who contribute financing, research, development, manufacturing or marketing skill by limiting the power of the licensor to reject executory contracts. See id.; Patrick Law, Intellectual Property Licenses and Bankruptcy-Has the IPLBA Thawed the "Chilling Effects" of Lubrizol v. Richmond Metal Finishers?, 99 CoM. L.J. 261 (1994). 
right under applicable nonbankruptcy law to specific performance of such contract) under such contract and under any agreement supplementary to such contract, to such intellectual property (including any embodiment of such intellectual property to the extent protected by applicable nonbankruptcy law), as such rights existed immediately before the case commenced, for-

(i) the duration of such contract; and

(ii) any period for which such contract may be extended by the licensee as of right under applicable nonbankruptcy law.

(2) If the licensee elects to retain its rights, as described in paragraph (1)(B) of this subsection, under such contract-

(A) the trustee shall allow the licensee to exercise such rights;

(B) the licensee shall make all royalty payments due under such contract for the duration of such contract and for any period described in paragraph (1)(B) of this subsection for which the licensee extends such contract; and

(C) the licensee shall be deemed to waive-

(i) any right of setoff it may have with respect to such contract under this title or applicable nonbankruptcy law; and

(ii) any claim allowable under section 503(b) of this title arising from the performance of such contract.

(3) If the licensee elects to retain its rights, as described in paragraph (1)(B) of this subsection, then on the written request of the licensee the trustee shall-

(A) to the extent provided in such contract, or any agreement supplementary to such contract, provide to the licensee any intellectual property (including such embodiment) held by the trustee; and

(B) not interfere with the rights of the licensee as provided in such contract, or any agreement supplementary to such contract, to such intellectual property (including such embodiment) including any right to obtain such intellectual property (or such embodiment) from another entity.

(4) Unless and until the trustee rejects such contract, on the written request of the licensee the trustee shall-

(A) to the extent provided in such contract or any agreement supplementary to such contract-

(i) perform such contract; or

(ii) provide to the licensee such intellectual property (including any embodiment of such intellectual property to 
the extent protected by applicable nonbankruptcy law) held by the trustee; and

(B) not interfere with the rights of the licensee as provided in such contract, or any agreement supplementary to such contract, to such intellectual property (including such embodiment), including any right to obtain such intellectual property (or such embodiment) from another entity.

The principal effect of section $365(\mathrm{n})$ is to enable most IP licensees to retain their rights under rejected license agreements. Congress did not, however, simply override the licensor's power to reject IP licensing agreements. Rather, it carefully crafted the mechanics and rights structure under section 365(n) to satisfy the needs of intellectual property licensees to continue their exploitation of intellectual property while shielding debtor-licensors from any additional burdens associated with the license.

Upon the rejection of a license falling within the Bankruptcy Code's definition of "intellectual property," 140 the licensee can either treat the rejection as a breach giving rise to a potential claim for money damages under section $365(\mathrm{~g})$, as with other rejected contracts, or retain the rights to the intellectual property covered by the license. Where the licensee elects to retain rights to the intellectual property, the debtor must permit the licensee to exercise its rights and the licensee must continue to pay royalties due under the licensing agreement. The licensee retains rights to the licensed property for the remaining life of the license plus "any period for which such contract may be extended by the licensee as of right under applicable nonbankruptcy law." ${ }^{141}$ By rejecting the licensing agreement, the debtor is relieved from performing any affirmative duties under the contract. The licensee waives any right of setoff it ${ }^{142}$ may have with respect to the licensing agreement and any claim for administrative expenses under the Bankruptcy Code, ${ }^{143}$ although the licensee may file a pre-petition claim under section $365(\mathrm{~g})$ for damages resulting from rejection of the licensing agreement ${ }^{144}$ and may seek damages from the debtor for breach of affirmative duties owed under the agreement, but only as a general unsecured creditor. The debtor is still bound by several passive obligations-

140. 11 U.S.C. $\S 101(35 A)(2000)$.

141. 11 U.S.C. $\$ 365(\mathrm{n})(1)(\mathrm{B})(\mathrm{ii})(2000)$.

142. A setoff is a settlement of mutual debt between a debtor in bankruptcy and a creditor through cancellation or reduction of a separate financial obligation owed by the creditor to the debtor. See 11 U.S.C. $\S 353$ (2000).

143. 11 U.S.C. $\S 365(\mathrm{n})(2)(\mathrm{C})(2000)$.

144. See In re Szombathy, 1996 WL 417121 , at *9 (Bankr. N.D. Ill. 1996), rev'd in part on other grounds, Szombathy v. Controlled Shredders, Inc., 1997 WL 189314 (N.D. Ill. 1997). 
such as adhering to confidentiality agreements and, in the case of an exclusive license, not licensing the technology to others-that are necessary for the licensee to enjoy the continued use and exploitation of licensed intellectual property. ${ }^{145}$

The IPBPA has proven to be somewhat complicated to apply due to several factors. First, Congress chose a limited definition of "intellectual property" for purposes of section 365(n). Most notably, the definition excludes trademarks. Second, there exists some ambiguity regarding the continuing obligations of licensors following rejection of an IP license and the retention of licensing rights by the licensee. Lastly, questions have arisen concerning the scope of the term "royalties."

\section{A. The Limited Scope of "Intellectual Property" Under Section 365(n)}

Section 365(n) applies only to licenses of "intellectual property" as defined in section 101 of the Bankruptcy Code:

(35A) "intellectual property" means-

(A) trade secret;

(B) invention, process, design, or plant protected under title 35;

(C) patent application;

(D) plant variety;

(E) work of authorship protected under title 17; or

(F) mask work protected under chapter 9 of title 17.

Several questions have arisen concerning the scope of this provision. First, while including many of the principal forms of intellectual property-patents, copyrights, and trade secrets - this list omits trademarks (and related forms of protection, such as trade dress). As we will see, this omission was intentional, which raises the related question of how licenses which bundle trademark and covered intellectual property rights should be handled. A second issue of scope that has been noted, though not adjudicated, is whether the narrow wording of section 101(35A)(E), which covers U.S. copyrights, also extends to foreign copyrights. A third issue concerns whether a record label (or other content distribution company) can invoke section $365(\mathrm{n})(1)$ to prevent a recording artist from getting out of an exclusive personal services contract tied to the creation of copyrightprotected works.

145. Id. at *10 (citing S. REP. No. 100-505 (1988), as reprinted in 1988 U.S.C.C.A.N. $3200)$. 


\section{Trademarks and Bundled IP Licenses}

The legislative history behind section $365(\mathrm{n})$ emphasizes concerns associated with emerging businesses in the computer software and biotechnology industries, ${ }^{146}$ for which patent, trade secret, and copyright licenses were of greatest significance. A spokesperson for the National Bankruptcy Conference considered the concerns raised by these industries to be more urgent than the needs of trademark licensees (such as those associated with franchise businesses) and opposed extending the legislation to include trademarks and related forms of intellectual property:

The Conference supports this legislation on a semi-emergency basis in order to further the activities of American research and development companies in the world race for technological leadership. The Conference sees no such emergency for and has no particular interest in, extending such protection to trademarks connected with traditional distributorships and retail businesses at this time. ${ }^{147}$

Congress adopted this view and omitted trademarks from the definition of "intellectual property."

Finally, the bill does not address the rejection of executory trademark, trade name or service mark licenses by debtor-licensors. While such rejection is of concern because of the interpretation of section 365 by the Lubrizol court and others, see, e.g., In re Chipwich, Inc., 54 Bankr. Rep. 427 (Bankr. S.D.N.Y. 1985), such contracts raise issues beyond the scope of this legislation. In particular, trademark, trade name and service mark li-

146. See Intellectual Property Contracts in Bankruptcy: Hearings on H.R. 4657 Before the Subcomm. on Monopolies and Commercial Law of the H. Comm. on the Judiciary, 100th Cong. 2d Sess. 13-24 (1988) (statement of James Burger, Chief-Counsel Government, Apple Computer, Inc.); A Bill to Keep Secure the Rights of Intellectual Property Licensors and Licensees Which Come Under the Protection of Title 11 of the United States Code, the Bankruptcy Code: Hearing on S.1626 Before the Subcomm. on Courts and Administrative Practice of the Senate Comm. on the Judiciary, 100th Cong. 1st Sess. 224-34 (1988) (statement of John L. Pickitt, President, Computer and Business Equipment Manufacturers Association).

147. Letter by George A. Hahn on behalf of the National Bankruptcy Conference (July 14, 1988), in THE AM. BANKR. INST. SURVEY: Hearing before the Subcomm. on Courts and Administrative Practice Of the Senate Comm. on the Judiciary on S. 1626, S.1358, S.1863, and S. 2279, 100th Cong., 2d Sess. at 344; see also A Bill to Keep Secure the Rights, supra note 146, at 4261 (statement of George A. Hahn on behalf of the National Bankruptcy Conference arguing that Congress need not "bring every retail franchise involving a trademark within the purview of the legislation, thus extending the reach of the bill far beyond what appears necessary"). 
censing relationships depend to a large extent on control of the quality of the products or services sold by the licensee. Since these matters could not be addressed without more extensive study, it was determined to postpone congressional action in this area and to allow the development of equitable treatment of this situation by bankruptcy courts. ${ }^{148}$

Relatively few cases have addressed the rejection of trademark licenses by debtor-licensees. Where the only significant intellectual property right licensed is a trademark, courts have had little difficulty concluding that trademark licenses cannot be retained under the authority of section $365(\mathrm{n}) .{ }^{149}$ Valid rejection of a trademark licensing agreement extinguishes the licensee's right to use the mark and the licensee is left with only a claim for breach of contract. ${ }^{150}$

A 1993 case, In re Matusalem, ${ }^{151}$ however, suggests that the IPBPA's legislative history could be invoked to protect trademark licensees, particularly in circumstances in which the trademark license is bundled with licenses of works that fall within the Bankruptcy Code's definition of "intellectual property." Recognizing that the IPBPA omitted "trademarks" from the definition of "intellectual property," the court nonetheless read

148. S. REP. No. 100-505, at 5 (1988), as reprinted in 1988 U.S.C.C.A.N. 3200, at 2-3. See generally David M. Jenkins, Licenses, Trademarks, and Bankruptcy, Oh My!: Trademark Licensing and the Perils of Licensor Bankruptcy, 25 J. MARSHALL L. REV. 143 (1991) (arguing that trademarks should have been included within the Bankruptcy Code's definition of "intellectual property").

149. See In re HQ Global Holdings, Inc., 290 B.R. 507, 512-513 (Bankr. D. Del. 2003); Raima UK Ltd. v. Centura Software Corp. (In re Centura Software Corp.), 281 B.R. 660 (Bankr. N.D. Cal. 2002); cf. Blackstone Potato Chip Co., Inc. v. Mr. Popper, Inc. (In re Blackstone Potato Chip Co., Inc.), 109 B.R. 557 (Bankr. D.R.I. 1990) (proffering no $\S 365(n)$ argument in a case in which the licensee opposed rejection of a trademark license).

150. Gucci v. Sinatra (In re Gucci), 126 F.3d 380, 394 n.1 (2d Cir. 1997) (invoking the maxim that rejection of a contract does not terminate or repudiate a contract but simply relieves the estate from its obligation to perform and citing Med. Malpractice Ins. Ass'n v. Hirsch (In re Lavigne), 114 F.3d 379, 387 (2d Cir. 1997)); see also Enter. Energy Corp. v. United States (In re Columbia Gas Sys.), Inc., 50 F.3d 233, 239 n.8 (3d Cir. 1995) (noting that rejection is equivalent to a nonbankruptcy breach); Cohen v. Drexel Burnham Lambert Group, Inc. (In re Drexel Burnham Lambert Group, Inc.), 138 B.R. 687, 703 (Bankr. S.D.N.Y. 1992) ("Rejection merely frees the estate from the obligation to perform; it does not make the contract disappear."). In In re HQ Global Holdings, the licensee argued that it was entitled to continue use of the trademark following a bankruptcy rejection of the licensing agreement so long as the debtor-licensor was relieved of all affirmative duties. The bankruptcy court held that rejection of the license agreement barred continued use by the licensee. 290 B.R. at 513.

151. 158 B.R. 514, 521-22 (Bankr. S.D. Fla. 1993). 
the legislative history of the Act to authorize courts to develop equitable standards for determining the treatment of trademark licenses in bankruptcy cases:

[T] he bill does not address the rejection of executory trademark, trade name or service mark licenses by debtor-licensors. While such rejection is of concern because of the interpretation of section 365 by the Lubrizol court . . , such contracts raise issues beyond the scope of this legislation. In particular, trademark, trade name and service mark licensing relationships depend to a large extent on control of the quality of the products or services sold by the licensee. Since these matters could not be addressed without more extensive study, it was determined to postpone congressional action in this area and to allow the development of equitable treatment of this situation by bankruptcy courts. ${ }^{152}$

The court did not, however, reach the question of how such standards would be determined or applied because it ultimately ruled that the debtorlicensor failed to justify its proposed rejection of the licensing agreement under the business judgment test. ${ }^{153}$ The court did note in passing that the harsh effect of rejection-to "utterly destroy" the licensee's businesswould weigh against an overly literal construction of the Bankruptcy Code, but it did not expressly conclude that it would have allowed retention of the trademark license if rejection had been adequately supported, nor did it mention the potential impact of its interpretation of section 365(n) upon trademark law's quality control requirements. ${ }^{154}$

Although commentators have speculated as to what form the equitable test alluded to in In re Matusalem might take, ${ }^{155}$ no subsequent case has

152. S. REP. NO. 100-505, at 6 (1988), as reprinted in 1988 U.S.C.C.A.N. 3200.

153. The debtor-licensor sought to reject a sub-franchise agreement under which the licensee acquired exclusive rights to the debtor's secret formula for making rum and exclusive rights to use the debtor's trademarked rum label in particular territories. Finding that the debtor's decision to reject the license agreement was motivated by a desire to exact revenge in an ongoing family feud rather than any plausible business purpose, the court turned away the debtor's proposed rejection of the licensing agreement.

154. In re Matusalem, 158 B.R. at 522.

155. See William L. Norton, JR., Norton Bankruptcy Law and Practice $\S 150: 18$ (2d ed. Supp. 2006); Kenneth A. Klee et al., The Effect of Bankruptcy on Intellectual Property Rights, in ALI-ABA COURSE OF STUDY 407, 412 (American Law Institute-American Bar Association Continuing Legal Education ed. 2001); Law, supra note 139; Primoff \& Weinberger, supra note 98; Stuart M. Riback, The Interface of Trademarks and Bankruptcy, 387 PLI/PAT 53, 75 (1994); Stuart M. Riback, Intellectual Property Licenses: The Impact of Bankruptcy, 672 PLI/PAT 201, 211 (2001), available at http://www.pli.edu/product/book_detail.asp?ptid=503\&stid=28\&id=EN00000000003935. 
developed or applied an equitable standard for addressing the retention of trademark rights under section 365(n), and the one court to address the treatment of bundled trademark and covered intellectual property rights distinguished this case. The court in In re Centura Software Corp. ${ }^{156}$ expressly declined to consider equitable considerations in adjudicating trademark rights post-rejection, although it suggested that it would have been able to consider such factors if the issue arose prior to court approval of a rejection of the license agreement. ${ }^{157}$ In essence, the court determined that section 365(n) has different implications depending upon whether it is invoked pre- or post-rejection. ${ }^{158}$ When invoked pre-rejection (as occurred in In re Matusalem) the court took the position that the licensee could have argued that the relatedness of the trade name to the protected property should allow it to "bootstrap ongoing trademark rights through an application of the business judgment rule," 159 notwithstanding the Bankruptcy Code's exclusion of trademarks. But since it was invoked after rejection had been approved, section 365(n) controlled the adjudication of the licensee's rights, and because trademarks are excluded from the scope of intellectual property to which section 365(n) applies, the court could not "weigh the equities" in assessing whether to allow the licensee to retain the trademark rights.

The In re Centura court both disputes whether In re Matusalem reads the Bankruptcy Code to allow for post-rejection consideration of the equities in determining whether trademark rights could be retained and disagrees with the assertion that the legislative history of the IPBPA can be read to authorize a court to engage in such an analysis. ${ }^{160}$ To a significant degree, the issue boils down to whether the relatively clear language of the statute-excluding trademarks from the definition of "intellectual property"--allows a court to look to the legislative history at all. The In re Matusalem court appears receptive to a more open-ended inquiry concerning the treatment of trademark rights before or possibly even after rejection has been approved, whereas the In re Centura court seeks to avoid reading trademarks into the definition of "intellectual property" in the Bankruptcy Code, preferring consideration of equitable factors solely during the rejection determination. Such an approach, while adhering closely

156. Raima UK Ltd. v. Centura Software Corp. (In re Centura Software Corp.), 281 B.R. 660 (Bankr. N.D. Cal. 2002).

157. The parties in In re Centura had stipulated to rejection of the trademark license. Id. at 672 .

158. The court based this interpretation on NORTON, supra note 155, $\S 150: 18$.

159. Quoting NORTON, supra note 155.

160. In re Centura, 281 B.R. at 672-73. 
to the letter of the Bankruptcy Code, leaves little leeway for considering equitable factors in view of the deferential nature of the business judgment rule. Where trademark rights are bundled with expressly protected intellectual property rights, the fact that the licensee will be able to continue to exploit the non-trademark rights could well affect the "business judgment" of whether to reject the trademark rights. This approach, however, provides little leeway for courts to balance the equities as between the licensor and the licensee. Rather, it would focus upon whether taking back only the trademark rights would be plausibly advantageous to the debtor. In view of the fact that the licensor might well be able to offer such rights back to the same licensee at a higher price, this legal standard would not appear to effectuate the "equitable treatment" that Congress expressed in the IPBPA's legislative history. Nor does it provide any basis for considering licensee interests in a pure (non-bundled) trademark situation.

\section{Foreign Copyrights}

The definition of "intellectual property" in section 101(35A) of the Bankruptcy Code covers "works of authorship protected under title 17" of the U.S. Code - the U.S. Copyright Act. The focus on copyrighted works protected by the U.S. Copyright Act raises a question as to the treatment of licenses to exploit foreign-produced works within the United States and licenses to exploit U.S. and foreign-produced works outside of the United States. ${ }^{161}$ The U.S. Copyright Act does in fact protect "works of foreign authorship" when the U.S. and the work's country of origin have treaties providing for reciprocal protections or when the work is first published in the United States. ${ }^{162}$ For example, works of British origin are protected by copyright in the U.S. under U.S. copyright law, not under British copyright law. Therefore, licenses that grant rights to exploit copyrights of works of foreign authorship in the United States would, assuming the existence of reciprocal treaties and the protectability of the work under U.S. law, fall within the scope of the Bankruptcy Code's definition of "intellectual property."

The treatment of licenses of works of foreign or U.S. authorship that grant the right to exploit outside of the United States is not dealt with quite as directly under the Bankruptcy Code. Take, for example, the relatively common case of a license of world-wide rights to a work of foreign or U.S. origin. The question arises whether a licensee would be able to retain exploitation rights outside of the United States under section 365(n) follow-

161. Cf. William M. Goldman, The Treatment of Intellectual Property in Bankruptcy, 747 PLI/PAT 461 (2003).

162. See 17 U.S.C. $\S 104$ (2000 \& Supp. 2004). 
ing a rejection of the license by the debtor-licensor. The debtor-licensor could argue that those rights are not rights under "Title 17" of the U.S. Code and hence fall outside the scope of section 365(n). A licensee seeking to retain such foreign exploitation rights (as well as the U.S. rights, which clearly fall within the ambit of section $365(\mathrm{n})$ ) could counter that the IPBPA defines intellectual property in terms of "works" as opposed to "rights," and since the license was for a "work" that is protected under Title 17, the IPBPA allows the licensee to retain its foreign (as well as U.S.) rights. Although the rather succinct legislative history of the IPBPA does not address this rather arcane question directly, the more general purposes of the statute- to encourage investment in intellectual property and to protect the right of licensees who contribute financing, research, development, manufacturing, or marketing skill by limiting the power of the licensor to reject executory contracts-clearly support the licensee's interpretation. There does not appear to be any countervailing policy opposing such an interpretation. Therefore, it would appear that all licensed copyright rights that are protected under the U.S. Copyright Act could be retained under section $365(\mathrm{n})$.

\section{Personal Services of Recording Artists}

As noted earlier, recording contracts between record labels and recording artists generally fall within the category of executory contracts, and therefore a recording artist can reject the contract in bankruptcy. The question thus arises whether a record label can seek to retain a recording artist's exclusive services through application of section 365(n) for the duration of the contract. ${ }^{163}$ In Cloyd v. GRP Records, ${ }^{164}$ the Sixth Circuit held that the definition of intellectual property did not extend to a person. It noted as well that reading the statute to extend that far would implicate the 13th Amendment's prohibition of involuntary servitude and that preventing the recording artist from performing free from contractual constraints would defeat the Code's purpose of granting the debtor "a fresh

163. Section $365(n)(1)(B)$ affords a licensee the option

to retain its rights (including a right [to] enforce any exclusivity provision of such contract, but excluding any other right under applicable nonbankruptcy law to specific performance of such contract) under such contract and under any agreement supplementary to such contract, to such intellectual property (including any embodiment of such intellectual property to the extent protected by applicable nonbankruptcy law)....

(emphasis added).

164. Cloyd v. GRP Records (In re Cloyd), 238 B.R. 328 (Bankr. E.D. Mich. 1999). 
start." ${ }^{165}$ Consequently, it concluded that section 365(n) did not apply to the personal services of a performing artist. ${ }^{166}$

\section{B. Licensor Obligations}

As noted above, section 365(n) relieves debtor-licensors of the responsibility to perform affirmative obligations under rejected contracts but requires that they adhere to certain passive obligations, such as nondisclosure provisions, covenants not to sue, and the like. The source and interpretation of the distinction between unenforceable affirmative duties and enforceable passive obligations, and the scope of these categories, requires a careful consideration of the text and legislative history of the IPBPA.

This issue mainly arises with covenants requiring that a licensor provide licensees with future improvements of licensed technology. ${ }^{167}$ These clauses can be particularly important for companies engaged in early stage technological research and those whose products depend on being interoperable. Potential licensees will be reluctant to license such technology if they cannot be assured of continued access to advances. Their choice of one technology provider over another may hinge on whether they can assure their customers of future compatibility with an emerging network technology. ${ }^{168}$ Yet, the possibility of such improvement clauses being rejected in bankruptcy places any such agreement under a cloud and could sour an otherwise promising deal. Due to the constraints imposed by bankruptcy law, the parties cannot contract around this situation short of the licensee acquiring the technology and technologists needed to develop it further, which will rarely be the optimal allocation of resources and responsibilities. In many ways, this situation parallels a principal justification for the enactment of section 365(n) in the first place. As noted in the legislative history,

When intellectual property is assigned rather than licensed, the original creator loses his personal stake. The licensee or assignee frequently is interested in the intellectual property for a specific application or geographic market. In order to assure the continued availability of the intellectual property against the contin-

165. See In re Monument Record Corp., 61 B.R. 866 (Bankr. M.D. Tenn. 1986) (citing Chattanooga Mem'l Park v. Still (In re Jolly), 574 F.2d 349 (6th Cir. 1978)).

166. Cloyd, 238 B.R. at 335-36. See generally Brewer, supra note 116.

167. See Law, supra note 139; Robert Canavan, Unsolved Mysteries of $\S 365(n)-$ When a Bankruptcy Technology Licensor Rejects an Agreement Granting Rights to Future Improvements, 21 SETON HALL L. REV. 800 (1991).

168. See Carl Shapiro \& Hal Varian, InFormation Rules: A STRategic Guide TO THE NETWORK ECONOMY (1998). 


\begin{abstract}
gency of the creator's bankruptcy, however, the party seeking the intellectual property for limited use must demand assignment of the property, notwithstanding that a license would otherwise serve his purpose. The creator then is either totally alienated from his creation or, at best, given a license by the assignee. Such circumstances create obvious disincentives to the full development of intellectual property. If the creator is unwilling to assign, in some instances, transactions simply are not completed. In others, the licensee discounts what he will pay to account for the risk now seen as inherent in Section 365. In short, Section 365 is resulting in undercompensation of U.S. inventors. Ironically, the present law, as it is now being interpreted by courts, can result in increased financial distress for the inventor, causing him to be shortchanged to adjust for a risk which under present law cannot be contractually removed if a license format is selected. ${ }^{169}$
\end{abstract}

To date, only one reported bankruptcy case addresses whether a future improvements clause is enforceable following rejection of the IP licensing agreement by the trustee/debtor and an election to retain licensing rights under section 365(n). In In re Szombathy, ${ }^{170}$ Szombathy licensed the right to manufacture and sell its patented tire shredding machine to Controlled Shredders, Inc. The license agreement extended to any patents which the licensor might later acquire as well as any improvements that the inventor might develop during the term of the patent. The licensor subsequently filed for bankruptcy and the trustee, appointed as part of a Chapter 7 proceeding, rejected the licensing agreement and sought to sell the debtor's intellectual property rights. Pursuant to section 365(n)(1)(B), Controlled Shredders elected to retain its rights to the debtor's patented technology under the licensing agreement and sought access to technological improvements that Szombathy had made following the filing of the bankruptcy petition. Szombathy sought a declaration from the court that neither he, nor any of his successors or any assignee of the Debtor's rights in the intellectual property, bore any affirmative obligations to share postpetition technological developments with Controlled Shredders.

The bankruptcy court found the text of section 365(n) to be clear and unambiguous in limiting a licensee's rights to intellectual property "in existence at the time of the bankruptcy filing." It pointed to a comment in the legislative history stating that the licensee is only "entitled to use the un-

169. S. REP. No. 100-505 (1988), as reprinted in 1988 U.S.C.C.A.N. 3200.

170. See In re Szombathy, 1996 WL 417121, at *9 (Bankr. N.D. Ill. 1996), rev'd in part on other grounds, Szombathy v. Controlled Shredders, Inc., 1997 WL 189314 (N.D. Ill. 1997). 
derlying intellectual property in the state that it existed on the day of the bankruptcy filing" 171 as well as the reference in section $365(\mathrm{n})(1)(\mathrm{B})$ affording the licensee such rights as "existed immediately before the case commenced." The court noted that although the debtor could be held to "certain obligations necessary" to implement the license agreement, such as a covenant not to reveal confidential information, the statute shielded the debtor from performing any affirmative obligations.

The court's rather literal reading of the statute arguably overlooks the broader policies that Congress sought to effectuate in the IPBPA. As the court recognized, the enforceability of passive obligations, such as the covenant not to reveal confidential obligations, derives from the legislative history. ${ }^{172}$ The only express obligation upon debtors in section $365(\mathrm{n})$ beyond making available the licensed intellectual property is the "right to enforce any exclusivity provision of such contract." Although not specifically cited by the court, section $365(\mathrm{n})(1)(\mathrm{B})$ appears to bar specific performance of "any other right under applicable nonbankruptcy law."

Nonetheless, Congress's interest in fostering technological innovation affords a basis for allowing bankruptcy courts a modicum of equitable discretion in assessing whether adherence to a future improvements clause amounts to an affirmative duty or a passive obligation necessary to effectuate the licensee's right to exploit the intellectual property it bargained for.

The bill recognizes that continued affirmative performance of an intellectual property license may be impractical; for instance, a trustee will generally be unable to perform covenants calling for continued research to improve licensed intellectual property. However, performance of covenants requiring no action by the trustee impose no burden on the estate and result in equity to the nonbreaching party and certainty to the economy as a whole. ${ }^{173}$

Thus, requiring a debtor to undertake research efforts that it would not otherwise pursue would clearly impose a significant burden upon the bankrupt estate and is beyond what Congress thought appropriate in balancing the rights of debtor-licensors and licensees. On the other hand, requiring a reorganized debtor to provide improvements it made voluntarily

171. Id. at *30 (quoting S. REP. No. 100-505 (1988), as reprinted in 1988 U.S.C.C.A.N. 3200).

172. The fact that trade secrets are included among the modes of "intellectual property" covered by the Bankruptcy Code provides a textual basis for enforcing confidentiality agreements under section $365(\mathrm{n})$.

173. S. REP. NO. 100-505 (1988), as reprinted in 1988 U.S.C.C.A.N. 3200. 
would not appear, in at least some commercial, technological, and industrial contexts, to impose a substantial or unanticipated burden on the debtor. Thus, an argument can be made on the basis of the legislative history of the IPBPA that bankruptcy courts should adjudicate the enforcement of improvement clauses on a case by case basis. ${ }^{174}$

But as the court found in In re Szombathy, the language of the statute may be too restrictive to support such an expansive interpretation. Under this view, the only obligations to which debtors may be held are providing access to the licensed intellectual property in the form it "existed immediately before the case commenced," any nondisclosure agreements, and, in circumstances where the licensee bargained for an exclusive license, refraining from licensing the covered intellectual property to others.

\section{Meaning of "Royalty Payments"}

Under section 365(n)(2)(B), licensees electing to retain rights under an IP license "shall make all royalty payments due under such contract for the duration of such contract and for any period described in paragraph (1)(B) of this subsection for which the licensee extends such contract." In practice, license agreements can entail several types of payments, only some of which are labeled "royalty payments." Although the statute does not define "royalty payments," the term has been broadly interpreted to include any payment for the use of intellectual property, regardless of nomenclature or whether based on a flat fee or percentage of sales. In In re Prize Frize, Inc., ${ }^{175}$ the license agreement distinguished between a "license fee" granting an exclusive license to utilize the proprietary rights and to manufacture, use, and sell a vending machine and "royalty payments" based on a percentage of sales. Following rejection of the contract and retention of rights by the licensee, the licensee sought to pay only what the license agreement designated as royalties and not the license fee (fixed sums payable over a prescribed time). The court held that, regardless of the nomenclature used in the license agreement, the term "royalty payments" in the statute encompassed all license fees to be paid by the licensee to retain its rights to use the intellectual property.

\section{Assessment and Reform}

Section 365(n) has solved the problem posed by the Lubrizol case and many analogous problems relating to bankruptcy of intellectual property

174. In the case of a Chapter 7 liquidation, enforcing an improvements clause as the debtor's inventors disperse could be difficult and costly.

175. See Encino Bus. Mgmt., Inc. v. Prize Frize, Inc. (In re Prize Frize, Inc.), 150 B.R. 456, 459-60 (B.A.P. 9th Cir. 1993), aff'd, 32 F.3d 426 (9th Cir. 1994). 
licensors. As explained above, however, several problems persist. The exclusion of trademark licenses from section 365(n) does not appear to be justified by the distinctive characteristics of trademark protection. The risk of licensor bankruptcy imposes undue and largely unavoidable uncertainty upon trademark licensees that could both discourage licensing and reduce the amount of investment in maximizing the value of licensee activities. Furthermore, the common bundling of trademark and other intellectual property rights exposes the over-inclusiveness of a rule allowing bankrupt licensors unfettered discretion to rescind trademark licenses. The Bankruptcy Code should provide bankruptcy courts discretion to consider a licensee's argument that a trademark license should be retained. The licensee should bear the burden of proving that retention of the license would not unduly impair the debtor-licensor in its fresh start (e.g., due to supervision costs) nor jeopardize the value of the trademark.

A second problem that has emerged under section 365(n) appears to be an overprotective approach to licensor obligations. Rather than relieving debtor-licensors of responsibility to perform any affirmative obligations, there is merit in allowing the bankruptcy court discretion to require performance of those obligations that have little or no cost for the reorganizing licensor that could afford substantial benefit to licensees. The clearest example is future improvement clauses. They can often be satisfied at minimal cost to the licensor. The risk of such obligations being jettisoned in bankruptcy could well impede efficient licensing. Thus, as with trademark licenses, Congress should amend section 365(n) to afford bankruptcy courts discretion to require debtor-licensors to perform relatively modest obligations that have great value to licensees following reorganization.

\section{THE LICENSEE BANKRUPTCY PROBLEM}

The inverse of the Lubrizol problem can occur when an IP licensee enters bankruptcy. The Bankruptcy Code's policy favoring alienability of assets jeopardizes the licensor's control of its intellectual property rights. The debtor-licensee may seek to assume the IP license and then assign it to a third party in exchange for direct payment or some other economic benefit to the estate. Where the licensee would assign the IP license to a third party that the licensor opposes, the licensor may find itself in a difficult circumstance. Take, for example, the case of an exclusive license to manufacture the licensor's product in exchange for a per unit royalty payment. If that exclusive license were to fall into the hands of a company producing a competing product, the new exclusive licensee might choose to halt production of the licensed product, thereby enhancing the market 
for its own product and denying the licensor revenue and consumer exposure. Even if the licensor placed a non-assignment clause in the licensing agreement, such clause would not be enforceable under general Bankruptcy Code provisions. ${ }^{176}$

The Bankruptcy Code addresses the assignability of contractual rights through several interrelated provisions. At the most general level, section 365(a) authorizes a trustee to assume or reject executory contracts. Once assumed, an executory contract can be assigned without the consent of the licensor (even if the agreement contains a non-assignment clause) ${ }^{177}$ unless the contract is, pursuant to section $365(\mathrm{c})$, one in which state or non-bankruptcy federal law would excuse the licensor from accepting performance from or rendering performance to an entity other than the debtor. ${ }^{178}$ Although general principles of contract law favor the free assignability of contractual rights unless the agreement, a statute, public policy, or principles of equity dictate otherwise, ${ }^{179}$ contract law prohibits the

176. See supra text accompanying note 68 .

177. See 11 U.S.C. $\S 365(f)(2000)$.

178. The Bankruptcy Code is ambiguous on this issue. Section $365(f)(1)$ states that "[e]xcept as provided in subsection ... (c)," the trustee may assign an executory contract notwithstanding "a provision in ... applicable law, that prohibits, restricts, or conditions the assignment of such contract." Section 365(c) states that the trustee may not assume or assign any executory contract ... if (1) (A) applicable law excuses a party, other than the debtor, to such contract ... from accepting performance from or rendering performance to an entity other than the debtor..., whether or not such contract or lease prohibits or restricts assignment of rights or delegation of duties; and (B) such party does not consent to such assumption or assignment.

These sections can be reconciled only by inferring that they refer to different conceptions of "applicable law." One commentator suggests that the distinction that most closely hews to Congress' intent reads section $(f)(1)$ to override general legislative provisions that prohibit or restrict assignment entirely while upholding, under subsection (c), general common law doctrines that excuse third parties from accepting or receiving performance from a third party. See Thomas M. WARD, InTellectual Property IN Commerce $\S 4: 93$ (2006).

179. See 3 Restatement (SECOND) OF CONTRACTS $§ 317(2)$ (1981), which states:

A contractual right can be assigned unless (a) the substitution of a right of the assignee for the right of the assignor would materially change the duty of the obligor, or materially increase the burden or risk imposed on him by his contract, or materially impair his chance of obtaining return performance, or materially reduce its value to him, or (b) the assignment is forbidden by statute or is otherwise inoperative on grounds of public policy, or (c) assignment is validly precluded by contract;

UCC $\S 2-210(2)$ (1999); 3 E. Allan FarnswORTH, FARNSWORTH ON CONTRACTS $\S \S 11.2,11.4$, at $61,82-84$ (2d ed. 1998). 
assignability of contracts for personal services involving unique skills or talents without the consent of the promisor. ${ }^{180}$

The courts have long held that the federal intellectual property policies of promoting innovation and the creative arts favor intellectual property owners having the ability to control the uses of their works. ${ }^{181}$ These policies disfavor assignability of such rights by licensees without the owner/licensor's consent. Some cases have also noted the personal nature of nonexclusive intellectual property licenses, which reinforces the unassignability of such rights without licensor consent. ${ }^{182}$

The application of section 365 (c) to preclude the assignability of intellectual property rights without licensor consent has been most strongly and clearly enunciated with regard to nonexclusive patent and copyright licenses. Nonexclusive licenses are viewed as conferring personal, as opposed to property, rights and hence most directly implicate the policy disfavoring free assignability by licensees. In some cases, courts consider equitable factors, such as the effects of an assignment on the character and profitability of a licensor's business ${ }^{183}$ and the motivations of the transferee, ${ }^{184}$ in determining whether a transfer may proceed. The law is less consistent with regard to the assignability of exclusive licenses. Intellectual property law tends to view such licenses as conferring property and not merely personal rights, which would favor greater freedom of transferability by the licensee. But, the one bankruptcy court decision to address the assignability of exclusive patent licenses barred the licensee from assigning the interest. ${ }^{185}$ In the copyright area, the law is deeply divided,

180. See, e.g., Breeden v. Catron (In re Catron), 158 B.R. 624, 627 (Bankr. E.D. Va. 1992), aff'd, 158 B.R. 629 (E.D. Va. 1993), aff'd, 25 F.3d 1038 (4th Cir. 1994); In re Taylor, 103 B.R. 511,516 (D.N.J. 1989), aff'd in part and appeal dismissed in part, 913 F.2d 102 (3d Cir. 1990); In re McVay, 169 B.R. 49, 51 (Bankr. W.D. Tenn. 1994).

181. See infra Section IV.B.

182. Id.

183. See PPG Indus., Inc. v. Guardian Indus. Corp., 597 F.2d 1090, 1096-97 (6th Cir. 1979); Syenergy Methods, Inc. v. Kelly Energy Sys., Inc., 695 F. Supp. 1362, 1364-65 (D.R.I. 1988) (examining whether transferee will effectively continue the business of the debtor/licensee); Nat'l Bank of Canada v. Interbank Card Ass'n, 507 F. Supp. 1113, 1124 (S.D.N.Y. 1980), aff'd, 666 F.2d 6 (2d Cir. 1981) (holding considerably larger size of successor entity justified licensor's objection to transaction); In re Van Ness Auto Plaza, Inc., 120 B.R. 545, 550 (Bankr. N.D. Cal. 1990); In re Alltech Plastics, Inc., 71 B.R. 686, 688-90, later proceeding at 5 U.S.P.Q.2d (BNA) 1806, $1810-13$ (Bankr. W.D. Tenn. 1987).

184. See Review Directories, Inc. v. McLeodusa Publ'n Co., No.1:99-CV-958, 2001 WL 1946328, at*3-4 (W.D. Mich. July 9, 2001) (holding that acquisition was not made solely to obtain licensed trademark).

185. See In re Hernandez, 285 B.R. 435 (Bankr. D. Ariz. 2002). 
with a recent Ninth Circuit decision interpreting the Copyright Act to prohibit the assignability of exclusive licenses without licensor consent ${ }^{186}$ and other courts interpreting the Copyright Act to allow free assignability of exclusive copyright licenses. ${ }^{187}$ The law regarding the assignability of trademark licenses is even less settled. Given the differing policies and doctrines across the modes of intellectual property protection, it is useful to examine each area separately.

Even before turning to the question of assignability of intellectual property licenses under section 365(c) and the non-bankruptcy "applicable law" that it incorporates by reference, however, there exists a rather technical antecedent question of whether a debtor in possession may even assume an intellectual property license that is not assignable under such nonbankruptcy law. The confusion arises as a result of ambiguous and potentially conflicting language in section $365(\mathrm{f})$.

\section{A. Assumability of License Agreements by Reorganizing Enterprises}

Section 365(c)(1) states that "a trustee may not assume or assign any executory contract [if applicable non-bankruptcy law excuses the nonbankrupt party] from accepting performance from or rendering performance to an entity other than the debtor or the debtor in possession." 188 Thus, under a literal reading of this provision, the trustee ${ }^{189}$ could not even assume a license if applicable law prohibited assignment. ${ }^{190}$ Courts describe this interpretation of the statute as the "hypothetical test" because it bars a debtor in possession from assuming a contract if applicable law would bar assignment by a hypothetical third party. ${ }^{191}$ By contrast, several courts and commentators believe that this interpretation conflicts with other aspects of the Bankruptcy Code, overlooks the legislative history of the

186. See Gardner v. Nike, Inc., 279 F.3d 774 (9th Cir. 2002).

187. See In re Golden Books Family Entm't, Inc., 269 B.R. 311, 318-19 (Bankr. D. Del. 2001); In re Patient Educ. Media, Inc., 210 B.R. 237 (Bankr. S.D.N.Y. 1997).

188. 11 U.S.C. $\$ 365(\mathrm{c})$ (2000) (emphasis added).

189. The courts agree that $\S 365$ (c)'s use of the term "trustee" includes Chapter 7 trustees and Chapter 11 debtors in possession. See Perlman v. Catapult Entm't (In re Catapult Entm't), 165 F.3d 747, 750 (9th Cir. 1999), cert. dismissed, 528 U.S. 924 (1999); Institut Pasteur v. Cambridge Biotech Corp., 104 F.3d 489, 492 n.7 (1st Cir. 1997); City of Jamestown v. James Cable Partners, L.P. (In re James Cable Partners, L.P.), 27 F.3d 534, 537, reh'g denied, 38 F.3d 575 (11th Cir. 1994); In re W. Elec., Inc., 852 F.2d 79, 82 (3d Cir. 1988).

190. The plain language of section 365(c) "link[s] nonassignability under 'applicable law' together with a prohibition on assumption in bankruptcy." EPSTEIN ET AL., supra note $55, \S 5-15$, at 258 .

191. See In re Catapult Entm't, 165 F.3d at 749. 
Act, and ignores the practical differences between assumption and assignment. ${ }^{192}$ These authorities advocate the use of an "actual test" for determining whether an executory contract may be assumed: the statute bars assumption by the debtor in possession only where the reorganization in question results in the nondebtor actually having to accept performance from a third party.

The controversy boils down to disagreement over statutory interpretation. The courts adhering to the hypothetical test conclude that the "statute speaks clearly, and its plain language does not produce a patently absurd result or contravene any clear legislative history." ${ }^{193}$ In their view, Congress should be held "to its words." 194 The courts adopting and commentators advocating the actual test find several troubling incongruities in the statute. ${ }^{195}$ The legislative history, although imprecise and complicated by the hasty passage of the relevant provisions, tends to buttress the argument that the protection afforded against unconsented assignment was not intended to apply to assumption of executory contracts by debtors in possession. ${ }^{196}$

192. See Institut Pasteur, 104 F.3d at 492 n.7; Summit Invest. \& Dev. Corp. v. Leroux (In re Leroux), 69 F.3d 608, 612 (1st Cir. 1995); Texaco Inc. v. La. Land \& Expl. Co., 136 B.R. 658, 668-71 (M.D. La. 1992); In re Cardinal Indus., Inc., 116 B.R. 964, 976-82 (Bankr. S.D. Ohio 1990); EPSTEIN ET AL., supra note 55, § 5-15, at 258-59; 3 LAWRENCE P. KING, COLLIER ON BANKRUPTCY $§ 365.06[1][d][$ iii] (15th ed. rev. 2006); Bussel \& Friedler, supra note 72.

194. In re Catapult Entm't, 165 F.3d at 754.

194. See id.; In re Sunterra Corp., 361 F.3d 257, 262 n.9 (4th Cir. 2004). But cf. In re Supernatural Foods, L.L.C., 268 B.R. 759 (Bankr. M.D. La. 2001) (questioning the analysis in In re Catapult Entm' $t$ ).

195. As articulated by the court in In re Cardinal Indus., 116 B.R. at 977, subsection $365(\mathrm{f})(2)(\mathrm{A})$ requires that a trustee must first be able to assume an executory contract before it can be assigned. Yet, subsection 365(c)(1) states that a trustee may not "assume or assign" a contract if applicable non-bankruptcy law prohibits an assignment. Given the requirement of subsection $365(\mathrm{f})(2)(\mathrm{A})$ that a contract be assumed before it can be assigned, it would have been sufficient for Congress to have stated in subsection 365(c)(1) that a trustee may not "assume" a contract, thereby rendering the text "or assign" superfluous. The Ninth Circuit, relying on Rieser v. Dayton Country Club Co. (In re Magness), 972 F.2d 689, 695 (6th Cir. 1992) (finding that subsections (c) and (f) have different scope), downplays any inconsistency in the plain meaning of the statute. In re Catapult Entm't, 165 F.3d at 751-53.

196. See H.R. REP. No. 96-1195, § 27(b) (1980), noting that:

This amendment makes it clear that the prohibition against a trustee's power to assume an executory contract does not apply where it is the debtor that is in possession and the performance to be given or received under a personal service contract will be the same as if no petition had been filed because of the personal nature of the contract. 
As a result of these differing interpretations of the Bankruptcy Code, a significant split exists over whether debtors in possession can even assume executory contracts where applicable law prohibits assignment. The Third, ${ }^{197}$ Fourth, ${ }^{198}$ Ninth, ${ }^{199}$ and Eleventh ${ }^{200}$ Circuits apply the hypothetical test-essentially barring assumption of executory contracts where assignment to third parties would be prohibited. The First Circuit ${ }^{201}$ and several lower courts ${ }^{202}$ apply the actual test-which determines whether an executory contract may be assumed based on the particular circumstances of the case:

The disjunctive "or" in $\S 365(\mathrm{c})$ is construed as the conjunctive "and." In applying the actual test, therefore, a court must make a case-by-case inquiry into whether the nondebtor party would be compelled to accept performance from someone other than the party with whom it had originally contracted, and a debtor would not be precluded from assuming a contract unless it actually intended to assign the contract to a third party. ${ }^{203}$

The weight of scholarly opinion, emphasizing the purposes of the Bankruptcy Code, the tension between subsections (c) and (f), and the ap-

See generally EPSTEIN ET AL., supra note 55, § 5-15, at 258-59. This report was deemed inconclusive on legislative intent by the courts applying a plain meaning interpretation based on several factors, including that it relates to an earlier proposal that was never enacted and reflected the view of only one House of Congress. See In re Sunterra, 361 F.3d at 269-70; In re Catapult Entm't, 165 F.3d at 753-54.

197. In re W. Elec., Inc., 852 F.2d 79 (3d Cir. 1988); see also In re Access Beyond Techs., Inc., 237 B.R. 32 (Bankr. D. Del. 1999).

198. In re Sunterra, 361 F.3d at 262 n.9; see also In re Travelot Co., 286 B.R. 447 (Bankr. S.D. Ga. 2002).

199. In re Catapult Entm't, 165 F.3d at 747.

200. City of Jamestown v. James Cable Partners, L.P. (In re James Cable Partners, L.P.), 27 F.3d 534, 537, reh'g denied, 38 F.3d 575 (11th Cir. 1994).

201. Institut Pasteur v. Cambridge Biotech Corp., 104 F.3d 489 (1st Cir. 1997); Summit Invest. \& Dev. Corp. v. Leroux (In re Leroux), 69 F.3d 608, 612 (1st Cir. 1995).

202. See, e.g., Texaco Inc. v. La. Land \& Expl. Co., 136 B.R. 658, 668-71 (M.D. La. 1992); In re GP Express Airlines, Inc., 200 B.R. 222, 231-33 (Bankr. D. Neb. 1996); In re Am. Ship Bldg. Co., 164 B.R. 358, 362-63 (Bankr. M.D. Fla. 1994); In re Fastrax, 129 B.R. 274, 277 (Bankr. M.D. Fla. 1991); In re Hartec Enters., Inc., 117 B.R. 865, 871-73 (Bankr. W.D. Tex. 1990), vacated on other grounds, 130 B.R. 929 (W.D. Tex. 1991); In re Cardinal Indus., Inc., 116 B.R. 964, 976-82 (Bankr. S.D. Ohio 1990).

203. In re Sunterra, 361 F.3d at 262 n.9 (citing Summit Invest. \& Dev. Corp. v. Leroux (In re Leroux), 69 F.3d 608, 612 (1st Cir. 1995)). 
parent intent of Congress as reflected in the legislative history, favors the application of the actual test. ${ }^{204}$

A 2002 bankruptcy court decision in a "hypothetical test" jurisdiction suggests that debtors in possession may be able to achieve the effects of the actual test through the application of another bankruptcy doctrine (the "ride through" doctrine), thereby lessening the difference between the two approaches in practice. The court in In re Hernandez ${ }^{205}$ determined that a reorganizing debtor could allow an executory contract that was neither affirmatively assumed nor rejected to pass through the bankruptcy unaffected. This so-called "ride through" doctrine originated in the preBankruptcy Code case of Consolidated Gas, Electric Light \& Power Co. of Baltimore v. United Railways \& Electric Co. of Baltimore, ${ }^{206}$ and has since been applied by several U.S. Courts of Appeals. ${ }^{207}$ Since executory contracts that "ride through" the bankruptcy proceeding are not formally assumed or rejected under section 365(a) (nor addressed in a Chapter 11 plan pursuant to section 1123(b)(2)), they are not entitled to the benefits afforded by 11 U.S.C. section 365 such as insulation from ipso facto provisions $(\S 365(\mathrm{e}))$ or the right to cure arrearages within a reasonable period of time $(\S 365(b))$. The ride through theory requires that the debtor take the benefits of the executory contract with all of the burdens, and failure to

204. See EPSTEIN ET AL., supra note 55, $\$ 5-15$, at 258-59 (advocating that "Congress should amend section 365 (c)(1) to make clear that 'applicable law' prohibitions on assignment do not preclude assumption in bankruptcy" and urging courts to permit a trustee or debtor to assume a contract notwithstanding a prohibition on assignment in the "applicable law" so as to ensure a harmony between subsections (c) and (f) of section 365); 3 KING, supra note 192, § 365.06[1][d][iii]; Bussel \& Friedler, supra note 72 (arguing that the "'actual test' yields correct results from the point of view of bankruptcy policy and allows results in bankruptcy to effectively mirror the results outside of bankruptcy").

205. 287 B.R. 795 (Bankr. D. Ariz. 2002).

206. 85 F.2d 799 (4th Cir. 1936).

207. See, e.g., Stumpf v. McGee (In re O'Connor), 258 F.3d 392 (5th Cir. 2001); Boston Post Rd. L.P. v. FDIC, 21 F.3d 477, 484 (2d Cir. 1994); Phoenix Mut. Life Ins. Co. v. Greystone III Joint Venture (In re Greystone III Joint Venture), 995 F.2d 1274 (5th Cir. 1991); In re Public Service Co. of New Hampshire, 884 F.2d 11 (1st Cir. 1989). It has also been recognized by several commentators and bankruptcy treatises. See, e.g., 3 KING, supra note 192, §365.02[2][d] ("If the debtor fails to either assume or reject the contract by separate order or in its plan, it appears that the contract would continue in existence .... if the debtor continues operating, arguably the contract passes through the bankruptcy and remains a liability of the reorganized entity."); Id. $\S 1123.02$ [2]; Bussel \& Friedler, supra note 72, at 338 n.48; Mark R. Campbell \& Robert C. Haste, Executory Contracts: Retention Without Assumption in Chapter 11-“"Ride-through" Revisited, 19 AM. BANKR. INST. J. 33 (2000); David G. Epstein \& Steve H. Nickles, The National Bankruptcy Review Commission's $\S 365$ Recommendations and the "Larger Conceptual Issues", 102 DICK. L. REV. 679, 689 (1998). 
comply with the burdens results in a breach of contract that cannot be discharged in a Chapter 11 plan. It remains to be seen whether other courts will apply the ride through doctrine in these circumstances in general, ${ }^{208}$ whether courts will disallow the application of the doctrine where a licensor objects, and what equitable standards will be used to determine whether such "ride throughs" will be allowed in a particular case. ${ }^{209}$

\section{B. Mode-Specific Analysis of Assignability of License Agreements}

Section 365(c)'s exception to the Bankruptcy Code rule supporting assignability of executory contracts turns on whether non-bankruptcy law would excuse the licensor from accepting performance from or rendering performance to an entity other than the debtor. It is therefore necessary to examine mode-specific rules regarding assignability as well as the bankruptcy cases applying these rules under section 365(c).

\section{Patent Licenses}

As discussed in the overview of intellectual property law, the Patent Act does not expressly prohibit or limit the assignability of patent licenses. The federal courts, however, have for more than a century and a half proscribed assignment of patents without the consent of the patent owner as a matter of federal common law. ${ }^{210}$ Building upon the constitutional principle that a patent affords its owner the right to exclude others from practicing the invention, the federal courts have viewed control of the patent to be a vital means of promoting innovation. This control is enhanced by affording the patent owner the default right to approve any transfer of a patent license. Therefore, the courts hold that the patent license, as a form

208. See Bussel \& Friedler, supra note 72, at 338 n.48 (2000) (suggesting that utilizing the "ride through" doctrine may "avoid or mitigate the risk of forfeiting valuable rights that might be nonassumable or nonassignable under the hypothetical test construction of $\S \S 365(\mathrm{c})$ and (f)").

209. The court in In re Hernandez reasoned that the four part test set out in Theatre Holding Corp. v. Mauro, 681 F.2d 102 (2d Cir. 1982), for determining whether a debtor should be permitted to delay the assumption or rejection decision serves as a useful guide for analyzing when ride through of an executory contract should be permitted. These four factors are: (1) the damage that other party to contracts would suffer, beyond compensation available under the Bankruptcy Code; (2) the importance of the contracts to the debtor's business and reorganization; (3) whether the debtor has had sufficient time to appraise its financial situation and potential value of its assets in formulating a plan; and (4) whether the exclusivity period has terminated. 287 B.R. at 806-07.

210. See generally H.H. Henry, Assignability of Licensee's Rights under Patent Licensing Contract, 66 A.L.R.2d 606 (2004). 
personal property, is "not assignable unless expressly made so" in the licensing agreement. ${ }^{211}$

\section{a) Nonexclusive Licenses}

The bankruptcy courts have found this rule to apply under section 365(c) to block the assignment of nonexclusive patent licenses without the consent of the patent owner. ${ }^{212}$ While noting that the rationale for a

211. See Lane \& Bodley Co. v. Locke, 150 U.S. 193, 195-96 (1893); Oliver v. Rumford Chem. Works, 109 U.S. 75, 82 (1883) (declaring that "the instrument of [a patent] license is not one which will carry the right conferred to any one but the licensee personally, unless there are express words to show an intent to extend the right to an executor, administrator, or assignee, voluntary or involuntary"); Hapgood v. Hewitt, 119 U.S. 226, 233-34 (1886); Troy Iron \& Nail Factory v. Corning, 55 U.S. 193, 216 (1852) (declaring that patent licenses are not assignable without owner's consent). For more recent affirmation of this doctrine, see Unarco Indus., Inc. v. Kelley Co., 465 F.2d 1303, 1306 (7th Cir. 1972).

Several commentators have argued that the Supreme Court's decision in Erie R.R. v. Tompkins, 304 U.S. 64 (1938), abrogating the general power of the federal courts to establish common law, overrides these earlier cases. See Aaron Xavier Fellmeth, Control Without Interest: State Law of Assignment, Federal Preemption, and the Intellectual Property License, 6 VA. J.L. \& TECH. 8 (2001); David R. Kuney, Intellectual Property Law in Bankruptcy Court: The Search for a More Coherent Standard in Dealing with a Debtor's Right to Assume and Assign Technology Licenses, 9 AM. BANKR. INST. L. REV. (2001); Carole A. Quinn \& R. Scott Weide, Violation of the Erie Doctrine: Application of a Federal Common Law to Issues of Patent License Transferability, 32 CREIGHTON L. REV. 1121 (1999); Daniel A. Wilson, Patent License Assignment: Preemption, Gap Filling, and Default Rules, 77 B.U. L. REV. 895 (1997). The Erie case itself determined that federal courts must look to state law in construing "contracts or other written instruments and especially to questions of general commercial law." 304 U.S. at 71. The Erie doctrine, however, leaves room for federal courts to apply federal common law rules where a specific showing has been made that applying state law will create conflict or will pose a threat to some federal policy or interest. See Atherton v. FDIC, 519 U.S. 213 (1997). On this basis, subsequent federal cases have upheld the long-standing federal common law rule of non-assignability of patent licenses unless expressly provided in the agreement. See Unarco Indus., 465 F.2d at 1306 (concluding that the patent "monopoly conferred by federal statute as well as the policy perpetuating this monopoly, so affects the licensing of patents, and the policy behind such licensing is so intertwined with the sweep of federal statutes, that any question with respect thereto must be governed by federal law" and therefore upholding the federal common law rule relating to the non-assignability of patent licenses); Wilson, supra, at 906-08. But see Farmland Irrigation Co. Inc., v. Dopplmaier, 308 P.2d 732, 740 (Cal. 1957) (applying state law favoring assignability of property interests after observing that the U.S. Supreme Court would be unlikely, in view of the modern tendency in favor of assignability, to uphold the non-assignability rule, and noting that " $[n]$ othing in the nature of patent licenses makes the rights conferred by them necessarily so personal that the parties must have intended that they be nonassignable").

212. See Perlman v. Catapult Entm't (In re Catapult Entm't), 165 F.3d 747, 750 (9th Cir. 1999), cert. dismissed, 528 U.S. 924 (1999); Institut Pasteur v. Cambridge Biotech 
federal common law rule barring assignability of patent licenses without licensor consent is not as strong as prior cases suggest, ${ }^{213}$ the Ninth Circuit in Everex held that federal patent policy justifies the application of a nonassignability rule under section 365(c):

The fundamental policy of the patent system is to 'encourag[e] the creation and disclosure of new, useful, and non-obvious advances in technology and design' by granting the inventor the reward of 'the exclusive right to practice the invention for a period of years'. Bonito Boats, Inc. v. Thunder Craft Boats, Inc., 489 U.S. 141, 150-51(1989). Allowing free assignability-or, more accurately, allowing states to allow free assignability- of nonexclusive patent licenses would undermine the reward that encourages invention because a party seeking to use the patented invention could either seek a license from the patent holder or seek an assignment of an existing patent license from a licensee. In essence, every licensee would become a potential competitor with the licensor-patent holder in the market for licenses under the patents. And while the patent holder could presumably control the absolute number of licenses in existence under a freeassignability regime, it would lose the very important ability to control the identity of its licensees. Thus, any license a patent holder granted-even to the smallest firm in the product market most remote from its own-would be fraught with the danger that the licensee would assign it to the patent holder's most serious competitor, a party whom the patent holder itself might be absolutely unwilling to license. As a practical matter, free assignability of patent licenses might spell the end to paid-up licenses such as the one involved in this case. Few patent holders would be willing to grant a license in return for a one-time lumpsum payment, rather than for per-use royalties, if the license could be assigned to a completely different company which

Corp., 104 F.3d 489, 492 (1st Cir. 1997); Everex Sys., Inc. v. Cadtrak Corp. (In re CFLC, Inc.), 89 F.3d 673, 679-80 (9th Cir. 1996).

213. Everex, 89 F.3d at 678-79 (explaining that the holding in Sola Electric Co. $v$. Jefferson Electric Co., 317 U.S. 173 (1942), that federal law preempted any state law which would estop a patent licensee from challenging a provision of the license as a violation of the Sherman Act, could better be attributed to the broad sweep of federal antitrust policy than federal patent policy, and that the rationale of Unarco Industries, 465 F.2d at 1306 , that the "monopoly conferred by federal statute as well as the policy perpetuating this monopoly, so affects the licensing of patents, and the policy behind such licensing is so intertwined with the sweep of federal statutes, that any question with respect thereto must be governed by federal law," seems insupportably broad given the general rule that most questions with respect to the construction of patent licenses are governed by state law). 
might make far greater use of the patented invention than could the original licensee. ${ }^{214}$

The court further recognized that nonexclusive patent licenses are personal in nature and not property interests. ${ }^{215}$

b) Exclusive Licenses

The assumability and assignability of exclusive patent licenses in bankruptcy is still largely an open question. ${ }^{216}$ The underlying patent law regarding assignability of exclusive licenses has never been definitively established. And the application of such law in the bankruptcy context is as yet undeveloped.

Focusing first on the non-bankruptcy "applicable law" bearing on assignability of exclusive licenses, no authoritative federal court decision directly states whether exclusive licenses are assignable without the consent of the licensor. ${ }^{217}$ It has long been established that unlike general questions of contract interpretation relating to patent licenses, which are governed by state law, ${ }^{218}$ patent license assignability questions are governed by federal law in order to promote federal policies and national uniformity in the interpretation of patent law. ${ }^{219}$

As noted previously, the federal law is clear that nonexclusive licenses cannot be assigned without consent of the licensor and that assignments of patents - the transfer of substantially all rights under the patent-generally include the right to transfer the patent to third parties. Exclusive licenses lie somewhere in between. Although not in a case directly addressing the

214. Id. at 679 .

215. Id. at 679; see also In re Alltech Plastics, Inc., 71 B.R. 686, 689 ("Given that the rights pursuant to a patent license are personal and nonassignable, it seems logical to conclude that the duties thereunder are also personal and nondelegable."), later proceeding at 5 U.S.P.Q.2d (BNA) 1806, 1810-13 (Bankr. W.D. Tenn. 1987).

216. See JAY DRATLER, JR., LiCENSING OF INTELlECTUAL PROPERTY § 1.06[2], at 155 (2001). The Ninth Circuit expressly stated in In re Catapult Entm't, 165 F.3d at 750 n.3 (citing Everex, 89 F.3d at 679), that "we express no opinion regarding the assignability of exclusive patent licenses under federal law, and ... we expressed no opinion on this subject in [the] Everex [case]."

217. Whatever the rule might be, the cases are clear that "[q]uestions with respect to the assignability of a patent license are controlled by federal law." PPG Indus., Inc. v. Guardian Indus. Corp., 597 F.2d 1090, 1093 (6th Cir. 1979). In so holding, courts generally have acknowledged the need for a uniform national rule that patent licenses are personal and non-transferable in the absence of an agreement authorizing assignment, contrary to the state common law rule that contractual rights are assignable unless forbidden by an agreement.

218. See Aronson v. Quick Point Pencil Co., 440 U.S. 257, 262 (1979).

219. PPG Indus., 597 F.2d at 1093. 
assignability of exclusive licenses, a recent Federal Circuit decision observes:

courts generally have acknowledged the need for a uniform national rule that patent licenses are personal and non-transferable in the absence of an agreement authorizing assignment, contrary to the state common law rule that contractual rights are assignable unless forbidden by an agreement. ${ }^{220}$

Authority can be found to support treating exclusive patent licenses like either nonexclusive licenses or full assignments depending upon the purpose that the law seeks to further. The most significant area in which the classification of exclusive patent licenses has arisen relates to the right to enforce patents against third party infringers, i.e., standing to sue. Patent law has traditionally limited the right to sue for infringement to the "patentee" (and successors in title to the patentee) ${ }^{221}$ in order to spare potential infringers from multiple suits by several nonexclusive licensees. ${ }^{222}$ In this limited context, courts have long held that exclusive licensees are more akin to assignees (or successors in title to a patent) and therefore have standing (jointly with the patentee) to sue alleged infringers: ${ }^{223}$

th[e] so-called exclusive licensee, while only licensee, comes so close to having truly proprietary interests in the patent, that the courts have held he is equitably entitled to sue on the patent, provided he joins the true proprietor of the patent in the suit. ${ }^{224}$

Since there is only one entity that may practice the invention in a particular geographic region or in a particular field of use, such a rule does not expose alleged infringers to multiple enforcement actions and protects the exclusive licensee's substantial interest in patent enforcement, even where the patent owner is reluctant to pursue actions. In this respect, then, the assignee and the exclusive licensee are treated in similar fashion (and differently from the nonexclusive licensee). ${ }^{225}$

220. Rhone Poulenc Agro, S.A. v. DeKalb Genetics Corp., 284 F.3d 1323, 1328 (Fed. Cir. 2002).

221. 35 U.S.C. $\S \S 281,100$ (d) (2000).

222. A.L. Smith Iron Co. v. Dickson, 141 F.2d 3, 6 (2d Cir. 1944).

223. See Waterman v. Mackenzie, 138 U.S. 252 (1891); Ortho Pharm. Corp. v. Genetics Inst., Inc., 52 F.3d 1026, 1032 (Fed. Cir. 1995); Phila. Brief Case Co. v. Specialty Leather Prods. Co., 145 F. Supp. 425 (D.N.J. 1956), aff'd, 242 F.2d 511 (3d Cir. 1957).

224. Phila. Brief Case, 145 F. Supp. at 428.

225. Some older cases treat exclusive patent licenses as "assignments" when they extend for the life of the patent. See Heywood-Wakefield Co. v. Small, 96 F.2d 496, 499 (1st Cir. 1938) (holding "license contract" in which patentee granted exclusive right un- 
It would be a mistake, however, to carry the analogy between the assignee and the exclusive licensee beyond this limited context of standing to sue without careful consideration of the terms of the licensing agreement. The classification of patent agreements depends on the extent to which rights are granted and not the labels attached to the documents. The Federal Circuit recognizes that an exclusive licensee holds some "of the proprietary sticks from the bundle of patent rights, albeit a lesser share of rights in the patent than for an assignment and standing to sue alone [i.e., without bringing in the patent owner as a co-party]."226 The court notes elsewhere that "[a]lthough our precedent has recognized that in some circumstances an exclusive patent license may be tantamount to an assignment of title to the patent, this is so only when "the licensee holds 'all substantial rights' under the patent." 227 In fact, the Federal Circuit expressly recognizes limits on the assignability of rights in a license agreement as a factor weighing in favor of finding a transfer of fewer than all substantial rights. ${ }^{228}$ From this it can reasonably be inferred that the Federal Circuit perceives non-assignability (without consent) to be an attribute of exclusive licenses.

In a particular situation, the licensor might provide separate exclusive territorial licenses to hundreds or thousands of separate entities. It might also limit the duration of such licenses to months or divide the rights up across dozens of separate fields of use. Therefore, the extent to which an exclusive license mirrors an assignment of substantially all rights under

der patent to make, use, and sell invention during term of patent was an assignment); Am. Type Founders v. Dexter Folder Co., 53 F. Supp. 602, 604 (S.D.N.Y. 1943) (construing an agreement granting an exclusive license for the term of the patent and reserving royalties to the patentee as an assignment and not a license); Lamar v. Granger, 99 F. Supp. 17, 36 (W.D. Pa. 1951) (same).

226. Ortho Pharm., 52 F.3d at 1031.

227. Rhone Poulenc Agro, S.A. v. DeKalb Genetics Corp., 284 F.3d 1323, 1334 (Fed. Cir. 2002) (quoting Textile Prods., Inc. v. Mead Corp., 134 F.3d 1481, 1484 (Fed. Cir. 1998)); see also Intellectual Prop. Dev., Inc. v. TCI Cablevision of Cal., Inc., 248 F.3d 1333, 1345 (Fed. Cir. 2001) (observing that an exclusive licensee receives more substantial rights in a patent than a nonexclusive licensee, but receives fewer rights than an assignee of all substantial patent rights).

228. See Prima Tek II, L.L.C. v. A-Roo Co., 222 F.3d 1372, 1380 (Fed. Cir. 2000); see also Pfizer Inc. v. Elan Pharm. Research Corp., 812 F. Supp. 1352, 1373 (D. Del. 1993) (reasoning that express prohibition on assignment of patent license without patent holder's consent, among other factors, precluded finding that agreement was an "assignment”); Raber v. Pittway Corp., 23 U.S.P.Q.2d 1313, 1314-15 (N.D. Cal. 1992) (same). But cf. Aluminum Co. of Am. v. Norton Co., Inc., 27 U.S.P.Q.2d 1317, 1318-19 (W.D. $\mathrm{Pa} .1993$ ) (holding that express prohibition on assignment of an exclusive patent license does not prevent a finding of a grant of "all substantial rights" in the subject patent thus allowing licensee to sue infringers). 
the patent (geographically, temporally, and fields of use) depends very much on the actual situation.

Thus far, only one bankruptcy court has been called upon to address the assignability of exclusive patent licenses. ${ }^{229}$ In In re Hernandez, the licensing agreement authorized three different entities to manufacture and sell products produced using the patented process. Although it prohibited outright assignment of the license, the agreement allowed each of the licensees to sub-license others to practice the invention. The agreement allowed the licensor to grant additional licenses (two per year), but only after an initial five year moratorium on further licensing. Although the agreement certainly grants more rights than a mere covenant not to be sued for infringement, it is somewhat of a stretch to characterize the agreement as "exclusive." Several entities were authorized to practice the invention in the same time period and territory and the licensor could, after five years, authorize additional licensees.

That being said, the court concluded that this agreement created an "exclusive license," requiring it to address whether exclusive licenses can be assigned in bankruptcy without the consent of the licensor. The court held that the granting of an exclusive patent license, while vesting the licensee with standing to enforce the patent, did not afford the licensee the right to assign the patent. The court provided only cursory analysis of the complex issues in play and ultimately based its decision on the federal patent policy interest in affording the patentee broad control over the identity of its licensees. Going beyond the prior cases, the court seems to have acknowledged that licensors of exclusive rights may have a special interest in determining the identity of their licensees.

The court's decision can be justified on grounds quite similar to those relied upon by the court in Everex. ${ }^{230}$ The Patent Act has been interpreted to afford the patentee broad discretion in the means of exploiting such right. A manufacturing patentee may choose to exploit such right entirely on its own and forgo any licensing. Inversely, a smaller inventor may choose to divide up the patent into several pieces by territory or field of use by extending several, limited exclusive licenses. For example, the patentee of a widget might grant licensee A, a well-known regional distribution company, an exclusive license to serve the northeastern states in ex-

229. See In re Hernandez, 285 B.R. 435 (Bankr. D. Ariz. 2002); cf. In re Supernatural Foods, L.L.C., 268 B.R. 759, 798-802 (Bankr. M.D. La. 2001) (finding that any transaction that does not fit squarely within the statutory and judicial requirements for an assignment is presumptively a license, whether exclusive or not, and, that all licenses are essentially covenants not to sue).

230. 89 F.3d 673, 679 (9th Cir. 1996). 
change for a sales-based royalty; licensee B, the southern states; licensee $\mathrm{C}$, the Midwest; and licensee D, the West. Providing each with an exclusive license for its region enhances its incentives to exploit the market for the patented invention. Suppose that licensee A goes into bankruptcy and seeks to assign its license. If the highest bidder were the developer of a competing product, the patentee would risk losing a large share of its market if A's trustee could unload the license to this purchaser. The licensor's inability to block such an assignment would seriously jeopardize its plan to get the most out of its patented technology, undermining the overarching policy goal of the patent system. Therefore, the case for finding a federal common law of non-assignability for exclusive licenses parallels the case for nonexclusive licenses. Unless the patentee has transferred so much of the patent bundle to an exclusive licensee as to constitute an assignment, it seems appropriate for a bankruptcy court to read the nonassignability of patent license rule to apply whether or not the license agreement granted exclusive or nonexclusive rights.

\section{c) Assumption of Licenses by Reorganized Debtors}

In the First Circuit and other jurisdictions applying the "actual test" for determining whether a debtor may assume an executory contract, ${ }^{231}$ the bankruptcy court must inquire into whether the licensor actually would be "forced to accept performance under its executory contract from someone other than the debtor party with whom it originally contracted." ${ }^{232}$ In essence, the court must assess whether a debtor-in-possession that seeks to assume the contract is a legal entity materially distinct from the prepetition debtor with whom the licensor contracted. In view of the extensive realignment of interests that occur in many Chapter 11 proceedings, this inquiry can raise complex questions.

In the most prominent such case to be decided, ${ }^{233}$ Institut Pasteur, a research and development company which owns various patented procedures for diagnosing HIV Virus Type 2, and Cambridge Biotech Corp. (CBC), a company that manufactures and sells HIV diagnostic kits, entered into mutual cross-license agreements whereby each acquired a non-

231. See Summit Invest. \& Dev. Corp. v. Leroux (In re Leroux), 69 F.3d 608, 612 (1st Cir. 1995); Texaco Inc. v. La. Land \& Expl. Co., 136 B.R. 658, 668-71 (M.D. La. 1992); In re GP Express Airlines, Inc., 200 B.R. 222, 231-33 (Bankr. D. Neb. 1996); In re Am. Ship Bldg. Co., 164 B.R. 358, $362-63$ (Bankr. M.D. Fla. 1994); In re Fastrax, 129 B.R. 274, 277 (Bankr. M.D. Fla. 1991); In re Hartec Enters., Inc., 117 B.R. 865, 871-73 (Bankr. W.D. Tex. 1990), vacated on other grounds, 130 B.R. 929 (W.D. Tex. 1991); In re Cardinal Indus., Inc., 116 B.R. 964, 976-82 (Bankr. S.D. Ohio 1990).

232. Leroux, 69 F.3d at 612 .

233. Institut Pasteur v. Cambridge Biotech Corp., 104 F.3d 489 (1 st Cir. 1997). 
exclusive perpetual license to use some of the technology patented or licensed by the other. In particular, $\mathrm{CBC}$ acquired the right to incorporate Institut Pasteur's HIV2 procedures into any diagnostic kits sold by $\mathrm{CBC}$ in the United States, Canada, Mexico, Australia, New Zealand, and elsewhere. Each cross-license prohibited the licensee from assigning or sublicensing to others, but authorized them to "extend to its Affiliated Companies the benefits of this Agreement so that such party shall remain responsible with regard [to] all [license] obligations."234

$\mathrm{CBC}$ filed a Chapter 11 petition and continued to operate its retroviral diagnostic testing business as debtor in possession. Its reorganization plan proposed that CBC assume the cross-licenses and continue to operate its retroviral diagnostics division utilizing Pasteur's patented HIV2 procedures, and sell all CBC stock to a large biotechnology corporation that was a direct competitor of Institut Pasteur. Institut Pasteur objected to the plan and specifically sought to block the assumption of the license, contending that the proposed sale of CBC's stock to Institut Pasteur's competitor amounted to a de facto "assignment" to a third party without its consent.

The bankruptcy court, district court, and ultimately the First Circuit ruled that the proposed sale of CBC stock to Institut Pasteur's competitor did not constitute a de facto "assignment" under the actual test, but rather was merely an assumption of the cross-licenses by the reorganized debtor under new ownership. Looking at the nature of the dealings leading up to the bankruptcy, the courts determined that the pre-petition licensing relationship between Institute Pasteur and $\mathrm{CBC}$ was neither "unique" nor "something in the category of a personal services contract." This analysis appears to run counter to most courts' recognition that nonexclusive patent licenses are "personal" in nature. Perhaps more importantly, the court's decision directly contradicts the primary policy purpose underlying the patent non-assignment doctrine: that the patentee should be able to control who acquires rights under its patent. Given the fact that the patentee's direct competitor gained effective legal control over the entity that assumed the license, the practical effect was that the competitor gained control of the license, precisely what patent law does not allow. ${ }^{235}$ The result in this case may also be an artifact of Massachusetts corporate law, under which

234. The agreements define an "Affiliated Company" as "an organization which controls or is controlled by a party or an organization which is under common control with a party." Id. at 490.

235. The courts might have been more sympathetic to Institut Pasteur had it insisted upon a provision in the cross-licensing agreements limiting or terminating CBC's rights in the event its stock ownership were to change hands. The record reveals that the parties had contracted for such a provision in other licenses between themselves. Id. at 494-95. 
stock sales do not trigger a change in outright title and ownership of a licensee-corporation's assets (including its patent licenses). ${ }^{236}$

\section{Copyright Licenses}

a) Nonexclusive Licenses

When the assignability of nonexclusive copyright licenses first arose in a bankruptcy context, the courts could not find any direct authority on whether copyright law requires consent by the licensor. Invoking the principle that "where precedent in copyright cases is lacking, it is appropriate to look for guidance to patent law 'because of the historic kinship between patent law and copyright law," ${ }^{237}$ the courts have imported the federal common law non-assignability doctrine from patent law to hold that a nonexclusive copyright license "is personal to the transferee ... and the licensee cannot assign it to a third party without the consent of the copyright owner." ${ }^{238}$ Therefore, a licensee cannot assign a nonexclusive copyright license without the consent of the licensor.

Without such a rule, copyright owners face many of the same risks and pitfalls as patent owners in devising a licensing regime. The risk of licensing rights being assigned without consent would undoubtedly discourage

236. See Seagram Distillers Co. v. Alcoholic Beverages Control Comm'n, 519 N.E.2d 276, 281 (Mass. 1988) (treating the corporation as a legal entity distinct from its shareholders). By contrast, California courts "have consistently recognized that an assignment or transfer of rights does occur through a change in the legal form of ownership of a business." SQL Solutions, 1991 WL 626458, at *3 (finding that a change in stock ownership by which the licensee became a wholly-owned subsidiary of another company effected an assignment of an intellectual property license); see also Trubowitch v. Riverbank Canning Co., 30 Cal.2d 335, 344-45 (Cal. 1947); People ex rel. Dep't of Pub. Works v. McNamara Corp. Ltd., 28 Cal. App.3d 641 (Cal. Ct. App. 1972); Sexton v. Nelson, 228 Cal. App.2d 248, 259 (Cal. Ct. App. 1964).

237. Harris v. Emus Records Corp., 734 F.2d 1329, 1333 (9th Cir. 1984) (quoting Sony Corp. of Am. v. Universal City Studios, 464 U.S. 417, reh'g denied, 465 U.S. 1112 (1984)). The historic kinship between patent and copyright law may well be appropriate in addressing the common "asset" qualities of these modes of intellectual property, but it is deeply flawed in addressing liability issues. See Peter S. Menell \& David Nimmer, Unwinding Sony, 95 CALIF. L. REV. (forthcoming 2007).

238. See Emus Records, 734 F.2d at 1333-34 (based on 1909 Copyright Act); In re Patient Educ. Media, Inc., 210 B.R. 237, 240 (Bankr. S.D.N.Y. 1997) (holding, under the 1976 Copyright Act regime, that the "conclusion and policy analysis in [Everex] applies with equal force in the analogous area of copyright law"); SQL Solutions, Inc. v. Oracle Corp., 1991 WL 626458, at *6 (N.D. Cal. 1991); see also Michaels v. Internet Entm't Group, Inc., 5 F. Supp. 2d 823, 834 (C.D. Cal. 1998); Seawind v. Creed Taylor, Inc. (In re Creed Taylor, Inc.), 10 B.R. 265, 267-68 (Bankr. S.D.N.Y. 1981) (upholding an anti-assignment clause in an exclusive license to manufacture and distribute sound recordings in part because of the "personal nature of certain licensing arrangements"). 
some efficient licensing relationships from being formed. Copyright owners sensitive to the identity of their licensees would be biased against licensing to entities that faced any significant risk of bankruptcy for fear that the works would simply wind up in the hands of the highest bidder.

b) Exclusive Licenses

Unlike the patent area, several courts have directly confronted the assignability of exclusive copyright licenses. Unfortunately, they are deeply split over their treatment.

The 1976 Copyright Act, unlike the Patent Act, specifically defines the granting of an exclusive license of any of the exclusive rights comprised in copyright as a "transfer of copyright ownership.,"239 Furthermore, section 201(d)(1) of the Act states that "ownership of a copyright may be transferred in whole or in part by any means of conveyance or by operation of law." Section 201(d)(2) provides that "[a]ny of the exclusive rights comprised in a copyright, including any subdivision of any of the rights specified by section 106, may be transferred ... and owned separately." Reading these provisions to provide that the holder of an exclusive license is entitled to all the rights and protections of the copyright owner to the extent of the license and the right to transfer such rights, ${ }^{240}$ several courts have held that the licensee under an exclusive license may freely transfer his rights. ${ }^{241}$ A recent Ninth Circuit decision, however, reads the Copyright Act to dictate the opposite conclusion. ${ }^{242}$

The Ninth Circuit in Gardner v. Nike reaffirmed its prior decision that "copyright licenses (whether exclusive or not) were 'not transferable as a matter of law" under the 1909 Act. $^{243}$ Only an assignment of the entire copyright could be assigned under the 1909 regime based on the doctrine of indivisibility ${ }^{244}$ and the policy concerns animating that Act. Although recognizing that the 1976 Act introduced the concept of divisibility into the Copyright Act, the court in Gardner read subsection 201(d)(1) narrowly to apply only to owners of the entire copyright, affording them the power to apportion their interest. It read the more specific second sentence

239. 17 U.S.C. $\S 101$ (2000 \& Supp. 2004).

240. 17 U.S.C. $\S 201(d)(2)(2000)$. See generally 3 NiMMER ON COPYRIGHT, supra note $30, \S 10.02[\mathrm{~A}](2006)$.

241. See I.A.E., Inc. v. Shaver, 74 F.3d 768, 775 (7th Cir. 1996); In re Patient Media Educ., 210 B.R. at 240.

242. See Gardner v. Nike, Inc., 279 F.3d 774 (9th Cir. 2002).

243. Id. at 777-78 (citing Harris v. Emus Records Corp., 734 F.2d 1329, 1333 (9th Cir. 1984)).

244. The doctrine of indivisibility prohibited a copyright owner from dividing the "bundle of rights." 3 NIMMER ON COPYRIGHT, supra note $30, \S 10.01$ [A]. 
of subsection 201(d)(2) ${ }^{245}$ to limit the rights of exclusive licensees to the "protection and remedies" of the Copyright Act. On this basis, it concluded that the particular transfer right of section 201(d)(1) and the first sentence of subsection 201(d)(2) apply only to copyright owners, not exclusive licensees. The court similarly dismissed the transferability argument based on the definition of "transfer of copyright ownership" in section 101 on the statutory interpretation principle that the more specific provisions should take precedence over the more general. The court bolstered its arguments by reference to the same policies that have been found to favor non-assignability of patent licenses without licensor consent: the promotion of creativity through control of licensing by the intellectual property owner.

The upshot of this decision is that at least in the Ninth Circuit, the "applicable law" prohibits the assignment of exclusive copyright licenses without the licensor's consent. Therefore, licensors can, under section 365 (c), block the assignment of exclusive copyright licenses by debtorlicensees. Whether this decision attracts a wide following across the circuits remains to be seen. ${ }^{246}$ It should be noted, though, that a Second Circuit decision preceding the Ninth Circuit's opinion construes subsection 201(d)(2) and the section 101 definition of "transfer of copyright ownership" quite similarly to Gardner v. Nike, although in a case resolving a dispute over the ownership of a copyright rather than assignability. ${ }^{247}$ In the bankruptcy context, however, the Delaware Bankruptcy Court in In re Golden Books Family Entertainment ${ }^{248}$ expressly rejected the line of rea-

245. Section 201(d)(2) provides:

Any of the exclusive rights comprised in a copyright, including any subdivision of any of the rights specified by section 106, may be transferred as provided by clause (1) and owned separately. The owner of any particular exclusive right is entitled, to the extent of that right, to all of the protection and remedies accorded to the copyright owner by this title.

17 U.S.C. $\S 201(\mathrm{~d})(2)$.

246. The leading copyright treatise concludes that an exclusive licensee, "having acquired 'title' or ownership of the rights conveyed, may reconvey them absent contractual restrictions." 3 NIMMER ON COPYRIGHT, supra note $30, \S 10.01$ [B][4].

247. See Morris v. Bus. Concepts, Inc., 259 F.3d 65 (2d Cir. 2001) (holding that an exclusive licensee of a certain copyright right is not a "copyright owner" under the Act).

248. 269 B.R. 311 (Bankr. D. Del. 2001). It should be noted that the court in In re Golden Books makes several errors in stating the Copyright Act provisions-adding an "s" to "protection" in subsection 201(d)(2) and suggesting the right to freely assign copyrights can be found in $\S 106$. The former error may have affected its understanding of the rather nuanced statutory construction followed by the Gardner court, and the latter error 
soning and result reached in Gardner v. Nike. ${ }^{249}$ The court found on very similar facts that the debtor-exclusive licensee of copyright rights could assign those rights without the consent of the licensor because the "applicable law" (copyright) did not excuse the licensor from accepting performance from or rendering performance to an entity other than the debtor.

\section{Trademark Licenses}

As with patent and copyright law, no federal or state trademark statutes expressly bar assignment or sub-licensing of trademark licenses without the licensor's consent. Analogizing between trademark and other intellectual property regimes is perilous because trademark law is premised on preventing consumer confusion and unfair competition, not promoting innovation. ${ }^{250}$ The promotion of innovation may flow indirectly from protecting the association between goods and their source by building goodwill to support investment, but trademark law finds its constitutional and jurisprudential basis in ensuring the marketplace's integrity. ${ }^{251}$ The only court to squarely address the issue of whether a trademark can be assigned by a debtor-licensee recognized this distinction, and developed an independent rationale for barring assignment. ${ }^{252}$

Despite this different motivation, the NCP Marketing court noted a key similarity between trademark licenses and patent and copyright licenses, namely that a licensor has a significant interest in a licensee's identity. ${ }^{253}$ In trademark law, this interest flows from the trademark owner's need to protect its mark's goodwill, value, and distinctiveness. ${ }^{254}$

may have based the alleged transfer right on the main rights provision of the Copyright Act rather than the more ambiguous provisions in subsections 201(d)(1) and (2).

249. The Delaware case was resolved after the lower court decision in Gardner, but before the Ninth Circuit affirmance (on substantially the same grounds). Therefore, the Delaware Bankruptcy Court was able to consider fully the reasoning that ultimately prevailed in the Ninth Circuit case.

250. The Trade-Mark Cases, 100 U.S. 82, 94-95 (1879).

251. See generally RESTATEMENT (THIRD) OF UNFAIR COMPETITION (1995).

252. N.C.P. Mktg. Group, Inc. v. Blanks (In re NCP Mktg. Group, Inc.), 337 B.R. 230, 235-36 (Bankr. D. Nev. 2005). An appeal in this matter is pending before the Ninth Circuit. N.C.P. Mktg. v. BG Star Prods., appeal docketed, No. 05-17384 (9th Cir. Dec. 20, 2005). A few other bankruptcy courts had suggested trademark licenses could not be assigned without consent, but based their holdings on other grounds. See In re Travelot Co., 286 B.R. 447 (Bankr. S.D. Ga. 2002); In re Luce Indus., Inc., 14 B.R. 529 (Bankr. S.D.N.Y. 1981).

253. In re NCP Mktg., 337 B.R. at 236 (citing Miller v. Glenn Miller Prods., 318 F. Supp. 2d 923, 933 (C.D. Cal. 2004)).

254. In re NCP Mktg., 337 B.R. at 236. 
Nonetheless, the result is the same- "trademark rights are personal to the assignee and not freely assignable to a third party."

Trademark law's core purpose provides a more direct basis for limiting assignability than either patent or copyright law. Whereas those innovation-focused bodies of intellectual property law support limitations on assignment through a somewhat indirect logical chain (as a means of bolstering the licensor's control, which in turn is thought to enhance incentives to innovate), trademark law's express doctrines prohibiting "naked licenses," invalidating assignments of trademarks in gross (i.e., without accompanying goodwill), and requiring the policing of licensing agreements, provide direct rationales for precluding the unauthorized assignment of trademark licenses. As Professor McCarthy, author of the leading treatise on trademark and unfair competition law, observes, "Since the licensor-trademark owner has the duty to control the quality of goods sold under its mark, it must have the right to pass upon the abilities of new potential licensees." 256

Despite this justification for barring licensees from assigning trademarks without consent, the case law prior to NCP Marketing does not uniformly reach this conclusion. A smattering of cases held that a trademark license could be assigned. ${ }^{257}$ The case In re Rooster, Inc. ${ }^{258}$ concerned the licensing system developed by the owner of the "Bill Blass" trademark. The licensor selected a group of fifteen sublicensees-based upon extensive investigations of financial status, physical plant, key personnel, existing products, channels of distribution and marketing, "taste level," and reputation in the industry-with whom it developed a cohesive menswear fashion line through a back-and-forth process of design and review. The licensor prepared an initial "clothing package" that included the tone and color pallet for the coming season. The sublicensees then developed a collection based upon that package and coordinated across their various choices. After the line had been approved, the sublicensees produced various items and sold them in the marketplace, providing a $7 \%$ royalty on gross sales to the licensor.

Rooster, one of the fifteen sublicensees, handled the tie collection. Although it had responsibility for researching libraries of patterns maintained by Italian silk producers to identify patterns reflecting the colors and tone

255. Id. (citing $4 \mathrm{~J}$. Thomas MCCARTHY, MCCARTHY ON TRADEMARKS $\S 25.33$ (4th ed. rev. 2006)).

256. 4 MCCARTHY, supra note $255, \S 25.33$.

257. See, e.g., In re Sunrise Rests., 135 B.R. 149 (Bankr. M.D. Fla. 1991); In re Rooster, Inc., 100 B.R. 228, 231-33 (Bankr. E.D. Pa. 1989).

258. 100 B.R. 228 (Bankr. E.D. Pa. 1989). 
set by the licensor, the licensor approved any pattern before it could go into production. Rooster would then manufacture and sell approved patterns with the Bill Blass trademark. After Rooster filed for bankruptcy, it sought to sell its rights under the licensing agreement to another fashion industry company. Blass objected, asserting its right to approve any such transfer. While recognizing the applicability of section 365 (c) to the assignment of this contract, the court narrowed its focus to whether the licensing agreement constituted "a contract for personal services, which applicable Pennsylvania law holds as unassignable." 259 Notwithstanding the clear trademark license in the agreement, the court did not look to the trademark law as an independent basis for blocking the assignment of the contract. Upon concluding that the debtor's performance under the licensing agreement did not draw "upon any special personal relationship, knowledge, unique skill or talent, $" 260$ the court ruled that the license could be assigned. Because "[a]ll parties concede[d] the applicability of Pennsylvania law to this dispute," the court never addressed whether federal trademark law would block the unconsented assignment of a license. ${ }^{261}$

The bankruptcy court in In re Sunrise Restaurants followed the same reasoning, holding that Burger King could not block the assignment of a number of the debtor-licensee's franchises because the Burger King franchise agreement was not a "personal services contract." ${ }^{262}$ The trustee proposed transfer of the agreement to a third party, to which the licensor, the holder of the Burger King trademark, objected. The franchise agreement contained a strict anti-assignment clause. In analyzing the licensor's objection to the assignment, the court focused solely on whether the agreement was "personal" in nature-i.e., whether it was based on special knowledge, skill, or talent of the licensee. The court did not consider the assignability of the trademark. The court approved the assignment on the grounds that the franchise did not involve special confidence or trust between the parties, or any special judgment, task, skill, or ability on the part of the licensee: $:^{263}$

The entire franchise operation is based on the strict rules and conditions imposed by the contract, and no retail operator is permitted to utilize his own independent culinary skills to cook hamburgers or to serve any other food items which are not generally served in Burger King establishments according to their

259. Id. at 232.

260. Id. at 233-35.

261. Id. at $232 \mathrm{n} .8$.

262. In re Sunshine Rests., 135 B.R. at 153.

263. Id. 
standard. This being the case, the objection by [Burger King Corporation] of the Debtor's right to assume or assign the franchise agreements and other contractual rights is without merit and must be rejected. ${ }^{264}$

A recent case directly analyzed section 365 (c) with regard to the assignability of trademarks, but its discussion ultimately turned out to be dicta because the court ruled that no trademark license was ever granted. ${ }^{265}$ Travelot, the developer of a hybrid travel agency service that combined web-based travel bookings with the customized services of a pre-screened, high quality travel agent in the destination locality, entered into an agreement with CNN to provide access to its service on CNN's website. The agreement involved several stages in which the parties were to find a technology partner who could provide the technical expertise needed to connect CNN.com visitors with Travelot's service providers and local travel agents, review marketing plans, and approve the functioning of the reservation system and the web content on an agreed-upon timetable. Travelot made substantial investments based on the expectation that it would be able to introduce its service through the CNN website. When it looked as though the agreement was destined to fall through on CNN's end, Travelot filed a bankruptcy petition seeking to assume the contract in a reorganization of the venture. CNN opposed the plan, arguing that under section $365(\mathrm{c})$ it was entitled to block the assumption of the contract because it would amount to an assignment (under the hypothetical test applied in the Eleventh Circuit) ${ }^{266}$ without its consent in violation of applicable trademark law. After reviewing trademark law authority on assignability, the court concluded that a "licensor need not accept performance from or render performance to an entity other than the licensee." ${ }^{267}$ Nonetheless, the court ultimately permitted the assumption of the contract on the ground that the licensing agreement did not in fact grant Travelot a license to use the CNN trademark. ${ }^{268}$

The case that comes closest to actually applying the background principles of trademark law to block an assumption of a trademark involved a license to manufacture and sell products under the well-known "Fruit of the Loom" mark by a debtor-licensee. ${ }^{269}$ Under the license, Fruit of the

264. Id.

265. In re Travelot Co., 286 B.R. 447 (Bankr. S.D. Ga. 2002).

266. See City of Jamestown v. James Cable Partners, L.P. (In re James Cable Partners, L.P.), 27 F.3d 534, 537, reh'g denied, 38 F.3d 575 (11 th Cir. 1994).

267. 286 B.R. at 455 .

268. Id. at $455-58$.

269. In re Luce Indus., Inc., 14 B.R. 529 (Bankr. S.D.N.Y. 1981). 
Loom reserved the right to approve any subcontractors and to inspect the quality of goods manufactured under its license. Prior to the bankruptcy, the licensee had subcontracted to a manufacturer approved by the licensor. As part of its plan to reorganize, the debtor sought to assume the license and subcontract the manufacturing and sale of the goods to a different subcontractor that was neither approved nor consented to by Fruit of the Loom. These goods would be sold directly by the subcontractor, which would first recoup the money spent on manufacturing, remit the license fees directly to Fruit of the Loom, and reserve the remaining profit, if any, for the debtor. At Fruit of the Loom's request, the court rejected this plan on the grounds that the arrangement amounted to a "court-directed assignment of a non-assignable license agreement" and that the licensor would not be "adequately assured of future performance" because the licensee would maintain no office, showroom, sales staff, or "leadership," and because the licensor would have no direct enforcement rights against the subcontractor. ${ }^{270}$ While reflecting the principles underlying section 365 (c), the court did not actually apply this provision or section 365(f) relating to the continued enforceability of an anti-assignment clause. Rather, the court viewed the case through the lens of section 365(b) and based its decision on the licensee's inability to provide "adequate assurance of future performance under the contract."

A line of cases addressing the transfer of automobile dealership franchise agreements also overlooks the role of trademark law in deciding whether to allow assignment, ${ }^{271}$ although most of these cases can be distinguished on the ground that state dealership transfer statutes prohibit an automobile manufacturer from unreasonably withholding consent to a transfer. ${ }^{272}$ Trademark licenses obviously serve a core function in the au-

270. Id. at 531-32; see also In re W. Elec., Inc., 852 F.2d 79, 82-84 (3d Cir. 1988) (holding that assumption of license agreement by bankrupt contractor as debtor-in-possession was not permitted, due to contractor's changed circumstances).

271. See, e.g., Leonard v. Gen. Motors Corp. (In re Headquarters Dodge, Inc.), 13 F.3d 674, 683 (3d Cir. 1993); In re Pioneer Ford Sales, Inc., 729 F.2d 27, 30 (1st Cir. 1984) (refusing to approve transfer because Ford had a reasonable basis for objecting to proposed transferee); Ford Motor Co. v. Claremont Acquisition Corp. (In re Claremont Acquisition Corp.), 186 B.R. 977, 991 (Bankr. C.D. Cal. 1995) (reversing order compelling assignment of GM franchise but affirming order compelling assignment of Ford franchise), aff'd, 113 F.3d 1029 (9th Cir. 1997); In re Tom Stimus Chrysler-Plymouth, Inc., 134 B.R. 676, 679 (Bankr. M.D. Fla. 1991); In re Van Ness Auto Plaza, Inc., 120 B.R. 545, 550 (Bankr. N.D. Cal. 1990) (upholding manufacturer's withholding of consent to transfer dealership).

272. See, e.g., CAL. VEH. CODE $\$ 11713.3$ (e) (West 2000). Such statutes seek to protect the licensors'/car manufacturers' interest in controlling their brand while maximizing the value of the bankrupt licensee's estate. Ford Motor Co. v. Claremont Acquisition 
tomobile dealership business. Many consumers consider the brand of automobile for which they are shopping to be a primary factor in choosing where to shop. Therefore, a strict application of section 365 (c) would allow the licensor to block the transfer of a dealership to another entity to the extent that the manufacturer's trademark was part of the transfer. In some states, however, statutes specifically address the transferability of automobile dealership franchises, ${ }^{273}$ although this raises the question of which law-the trademark law or the state dealership transfer laws-takes precedence under section 365(c).

In summary, trademark law generally bars the assignment of licenses without the licensor's consent. Nevertheless, several bankruptcy courts have applied alternative standards to determine whether assignments involving trademark licenses should be allowed. Two justifications drive these cases. The first set of cases analyzes assignability only under the law of personal service contracts and fails to consider trademark law principles. ${ }^{274}$ The second set of cases appears to stem from a concern that the trademark license is but one aspect of the debtor's business and that blocking assignment could impose particularly harsh effects upon the bankruptcy estate. This second justification leads the courts to apply general equitable standards. ${ }^{275}$ The opinions appear to be trying to determine the

Corp. (In re Claremont Acquisition Corp.), 186 B.R. 977, 983-84 (Bankr. C.D. Cal. 1995), aff'd, 113 F.3d 1029 (9th Cir. 1997); In re Van Ness Auto Plaza, 120 B.R. at 548-49. Not all of the cases dealing with this issue arise in states with such statutes, however. See In re Bronx-Westchester Mack Corp., 20 B.R. 139, 143 (Bankr. S.D.N.Y. 1982) (permitting the assignment of a "Mack" truck dealership over the licensor's objection).

273. See, e.g., CAL. VeH. CODE $\S 11713.3(d)(1)$ (West 2000); Fla. Stat. ANN. $\S 320.643(1)(a)$ (West 2007); IND. CODE $\S 9-23-3-11$ (2007); R.I. GEN. LAWS $\S 31-5.1-$ 4(c)(7) (2006); ARK. CODE ANN. § 4-72-205 (West 2007); N.J. STAT. ANN. § 56:10-6 (West 2007); see also Michelle Morgan Harner, Carl E. Black \& Eric R. Goodman, Debtors Beware: The Expanding Universe of Non-Assumable/Non-Assignable Contracts in Bankruptcy, 13 AM. BANKR. INST. L. REV. 187, 226-31 (2005); Elaine D. Ziff, The Effect of Corporate Acquisitions on the Target Company's License Rights, 57 Bus. LAW. 767, 782 (2002); Gary Michael Brown, Note, State Motor Vehicle Franchise Legislation: A Survey and Due Process Challenge to Board Composition, 33 VAND. L. REV. 385 (1980); Stewart Macaulay, LaW and the Balance of Power: The automobile ManuFACTURERS AND THEIR DEALERS (1966).

274. See In re Lil' Things, Inc., 220 B.R. 583, 587-88 (Bankr. N.D. Tex. 1998) (explaining why courts initially misunderstood the scope of "applicable law" under section 365(c)); In re Sunrise Restaurants, Inc., 135 B.R. 149 (Bankr. M.D. Fla. 1991); In re Tom Stimus Chrysler-Plymouth, Inc., 134 B.R. 676 (Bankr. M.D. Fla. 1991); Varisco v. Oroweat Food Co. (In re Varisco), 16 B.R. 634 (Bankr. M.D. Fla. 1981); In re Taylor Mfg., Inc., 6 B.R. 370 (Bankr. N.D. Ga. 1980).

275. See Celia F. Rankin, Intellectual Property Licenses and Bankruptcy, 32 CoLo. LAW. 63, 65 (2003); Neil S. Hirshman, Michael G. Fatall \& Peter M. Spingola, Assigna- 
extent to which the trademark license is truly personal in nature-i.e., whether there are objective standards for ensuring that the trademark owner will not be hurt by a third party acquiring the license. ${ }^{276}$ If such standards exist, then the court can assure itself that the licensor will not be unduly injured by a change in the identity of the licensee. Given the structure of section 365(c) and the applicable trademark law, however, it is difficult to square these cases with the Bankruptcy Code.

\section{Trade Secret Licenses}

Trade secret licenses, by their very nature, specify clearly the parties with whom information may be shared and preclude disclosure of information to others. Since disclosure by the licensee would destroy the secrecy essential to this form of intellectual property, the licensor necessarily gives careful consideration to the risks posed by sharing the information with a particular potential licensee, and the licensee receives the secret information under conditions of trust and confidence. This agreement is highly personal in nature, so it seems likely that trade secret law would bar assignment of trade secret licenses without the consent of the licensor. ${ }^{277}$ Perhaps not surprisingly, there are no cases applying section $365(\mathrm{c})$ to know-how licenses. ${ }^{278}$

bility of Intellectual Property Licenses in Bankruptcy: Navigating the Murky Waters of Section 365, INTELL. PROP. LAW NEWSL., Fall 2002, at 15; Ziff, supra note 273, at 779. 83.

276. The court in Bronx-Westchester permitted the assumption of a truck dealership on the following reasoning:

[Section] 365(c)(1)(A) bars a debtor from assigning an executory contract if applicable law excuses a party from accepting performance from or rendering performance to the debtor. This provision relates to executory contracts that are personal in nature. A distributorship or franchise agreement which does not depend upon a special relationship between the parties is not within the reach of this exception. In re Varisco, 16 B.R. 634 (Bankr. M.D. Fla. 1981). In the instant case, as in the Varisco case, the original distributorship agreement with Mack Trucks, Inc. was entered into with the debtor's predecessor. The debtor acquired the dealership by purchase. There is no special personal relationship between the parties to the contract in question other than the dealer's ability to sell Mack Trucks and support the operations called for under the contract.

In re Bronx-Westchester Mack Corp., 20 B.R. at 142.

277. See RAYMOND T. NimMER, 2 INFORMATION LAW $\S 11: 163$ (2004). In a California Supreme Court decision from a half century ago, however, Justice Traynor emphasized California's strong public policy favoring the free assignability of contracts (including licenses) and held that such public policy should apply to trade secret and patent licenses notwithstanding federal cases to the contrary. See Farmland Irrigation Co. v. 


\section{Avoiding Opportunism and Promoting Debtor Estate Value in the Licensee Bankruptcy Context}

From an economic standpoint, licensee bankruptcy poses two opportunism problems. First, the trustee or debtor estate may be able to obtain an unjustified elevated price for an IP license by selling it to an unsuitable third party. Second, a licensor might unreasonably withhold consent to a wealth-enhancing assignment of an IP license in order to extract goodwill associated with the debtor's business.

\section{Assignment to Hostile Third Party or Retention by Hostile Debtor}

Following bankruptcy, the trustee or debtor estate seeks to maximize the value of the remaining assets or prospective value of the reorganized enterprise. Where the estate holds intellectual property licenses, the goal will be to assign or deploy the licenses in such a way to maximize its value from the standpoint of the estate. At auction, the intellectual property license may be of most value to a less scrupulous enterprise than the debtor, and quite possibly an entity that the licensor would not have contracted with or would have demanded more favorable terms from. In the worst case scenario, the licensee might sell an exclusive license to the licensor's prime competitor. The competitor might suppress or shut down sales of the licensed product as part of its business strategy to push the licensor from the market. Alternatively, a reorganizing debtor might retain the license but shift its business strategy in such a way as to erode or destroy the value of the intellectual property (from the intellectual property owner/licensor's perspective). The Institut Pasteur case arguably falls into this category. ${ }^{279}$ In each of these scenarios, the debtor's use of the intellectual property will likely result in an overall loss of economic value because the loss to the intellectual property owner will exceed the benefit to the bankrupt estate.

Section 365(c) provides a critical safety valve to prevent these undesirable outcomes. Unfortunately, the application of section $365(\mathrm{c})$ is confused by two ambiguities: (1) whether the hypothetical or actual test ap-

Dopplmaier, $48 \mathrm{Cal}$. 2d 208 (Cal. 1957). The aspect of the decision relating to assignability of patent licenses has since been overruled, see Everex Sys., Inc. v. Cadtrak Corp. (In re CFLC, Inc.), 89 F.3d 673, 679 (9th Cir. 1996), discussed supra note 215, but the trade secret ruling has never been withdrawn or reversed. Since trade secret licenses are governed solely by state law, it is conceivable that a bankruptcy court applying California law could find trade secret licenses to be assignable even without licensor consent.

278. See Hirshman et al., supra note 275, at 16.

279. See supra text accompanying notes 233-236. 
plies, and (2) what the interaction is between subsection ( $f$ )(1)'s nullification of anti-assignment "applicable law" and subsection (c)'s excuse under "applicable law." Congress should clarify the Bankruptcy Code to address the ex post opportunism threat to the intellectual property laws by establishing that subsection (f)(1) does not stand in the way of background applicable law that affords intellectual property owners discretion to block unauthorized assignments of licenses. ${ }^{280}$ Furthermore, the Code should allow IP licensors to object to retention of licenses by reorganizing debtors that pose a risk to the value of the intellectual property. To prevent this power from being used to extract greater value from the debtor-licensee than the costs imposed on the licensor, courts should approve assumption of a license when the reorganized entity will continue to operate within the circumstances under which the license was made. The courts should only disapprove when the reorganization plan so changes the use of the intellectual property as to constitute an effective assignment to an entity that the licensor would have reasonable grounds to oppose. These changes would prevent unjust enrichment by debtor estates and needless erosion or destruction of intellectual property value. In so doing, they promote the purposes of the intellectual property system without undermining the bankruptcy system.

\section{Equitable Division of Bilateral Goodwill}

The second problem is more subtle and reveals a fundamental tension between the goals of intellectual property laws (or at least trademark law) and the goals of the bankruptcy system. It is well illustrated by the automobile franchisee bankruptcy scenario discussed earlier. ${ }^{281}$ Suppose that the Bailey family becomes a franchisee for Potter Motor Company in Bedford Falls. ${ }^{282}$ Over several decades, Bailey Potter Motors develops a great reputation for its products, sales, civic responsibility, and fair dealing. Bailey Potter Motors sponsors various youth sports leagues, contributes to park clean-up efforts, and generally earns the respect of the local marketplace. Unfortunately, George Bailey's Uncle Billy, who handles accounting for the franchise, misplaces a large bank deposit, forcing the Bailey Potter Motors into bankruptcy. The trustee in bankruptcy seeks to assign

280. The Supreme Court could also provide clarity by interpreting section $365(f)(1)$ so as not to negate section 365 (c).

281. See supra text accompanying note 273 .

282. Old movie fans may recognize some of these parties from Frank Capra's classic film, IT's A WONDERFUL LiFE (Liberty Films 1946), starring Jimmy Stewart, Donna Reed, and Lionel Barrymore. 
the Potter Motors license to a reputable successor who is willing to pay top dollar to continue the Bailey Potter Motors tradition.

Even though this assignment does not pose any significant economic threat to Potter Motors Company, and would likely result in continued strong sales for the licensor in Bedford Falls, Potter Motors could block the assignment of the Bailey Potter Motors dealership on the ground that the Potter Motors trademark cannot be assigned without its consent. ${ }^{283}$ By blocking the deal, Potter Motors would be able to deprive the debtor estate of goodwill that it established over its many years in operation. It could then license another party (perhaps even the same one that the Bailey Potter Motors trustee was considering) and derive some or all of the Bailey goodwill.

This scenario seems to be part of the motivation behind the federal and state laws that protect automobile dealers against overreaching by motor vehicle manufacturers. ${ }^{284}$ By prohibiting manufacturers from blocking assignment of dealerships unless they can establish good cause (such as a bad credit record or lack of experience on the part of proposed assignee), the law effectively allows the goodwill earned by the franchisee to remain an asset of the estate.

This rule avoids ex post opportunism on the part of the intellectual property licensor while affording safeguards (an opportunity to question the ability of the proposed assignee) against erosion of their intellectual property interests. This rule could be generalized beyond the automobile franchise context. Whenever the debtor estate has established goodwill that an intellectual property licensor seeks to extract through unreasonable withholding of consent, a bankruptcy court should be able to allow the assignment to go forward so long as safeguards are in place to protect the intellectual property. It should be noted, however, that this dual goodwill scenario is unlikely to arise commonly. Were Congress to bestow such power to bankruptcy courts - essentially, to allow them to determine whether consent to the assignment of intellectual property licenses is being unreasonably withheld - then courts should ensure that the proposed assignee amply satisfies the licensor's criteria. Courts should be reluctant to second guess the licensor unless its own patterns of licensing suggest that it is withholding consent unreasonably.

283. See Miller v. Glenn Miller Prods., 318 F. Supp. 2d 923, 933 (C.D. Cal. 2004) ("[A] trademark licensee may not sub-license a mark without express permission from the licensor.”); N.C.P. Mktg. Group, Inc. v. Blanks (In re NCP Mktg. Group, Inc.), 337 B.R. 230, 235-36 (Bankr. D. Nev. 2005).

284. See supra text accompanying note 273 . 


\section{MANAGING INVESTOR RISK: SECURITIZATION OF IP ASSETS}

Investors in creative enterprises-whether they are biotechnology start-ups or Hollywood productions-face special problems in protecting their investments against business failure. In more conventional investments, the proceeds may well be devoted to the acquisition of tangible assets-such as real estate, buildings, or chattels. The investors can condition their investments on those assets being put up as collateral. Should the entity fail, the investors will at least have protection up to the value of the collateral so long as they have "perfected" their security interest under applicable state or federal law. ${ }^{285}$ If the claim exceeds the value of the collateral, then the remaining balance becomes part of the pool of general unsecured claims.

Although intangible assets can serve as collateral, they are typically much more difficult to identify, trace, and liquidate. In addition, they can change as a project progresses. For example, a research project may begin as a trade secret and mature into a patented invention. Uncertainty surrounding the rules for perfecting security interests in intellectual property creates problems in securing investments in creative enterprises. This Part begins with an overview of the general rules for perfecting security interests. It then examines the specific challenges of perfecting security interests in intellectual property. It concludes with several proposals for simplifying, integrating, and harmonizing the process for perfecting IP collateral.

\section{A. UCC Article 9: Default Rules for Perfecting Security Interests}

Article 9 of the Uniform Commercial Code ("UCC") provides the primary governance regime for protecting consensual security interests in personal property. This code, which was substantially revised in the late

285. Perfecting a lien refers to the process of recording the lien pursuant to applicable law. An unperfected security interest may be valid between the contracting parties, but does not bind those who later acquire a security interest if they lack actual knowledge of the prior lien. A perfected interest serves notice on all subsequent creditors.

The bankruptcy estate honors the principle of derivative title and therefore takes property subject to all liens-perfected and unperfected. See generally EPSTEIN ET AL., supra note 55, §3-18. The trustee can, however, avoid unperfected liens under its avoiding powers. Under section 544 of the Bankruptcy Code, the trustee in bankruptcy obtains the rights and powers of a "hypothetical lien creditor" who obtains a judicial lien as of the date of filing the bankruptcy petition. This judicial lien takes priority over the unperfected lien, thereby enabling the trustee to avoid any transfer of property of the debtor that is avoidable by such a judicial lien creditor. See 11 U.S.C. $\S \S 544(a), 545(2)$ (2000). Under $\S 547(\mathrm{~b})$, the trustee can avoid perfected security interests that constitute preferential transfers. 
1990 s, has been adopted by every state. ${ }^{286}$ It seeks to provide a uniform, inexpensive, reliable, and effective process for protecting security interests.

\section{Attachment of Security Interests}

In a conventional secured transaction, a debtor borrows money in exchange for a promise to repay the loan. The lender, as a means of ensuring repayment, obtains a security agreement from the debtor by "attaching" particular assets of the debtor to serve as collateral for the debt. ${ }^{287}$ Article 9 permits lenders to attach not only existing tangible assets, such as inventory or equipment, but also intangibles, such as the debtor's stream of income and intellectual property. ${ }^{288}$ Article 9 also allows lenders to attach future assets of the debtor, also known as "after-acquired collateral." Secured creditors often claim all of a debtor's assets as collateral.

The purpose of the security interest is to provide a means to satisfy the debt should the borrower default. Rather than first having to go to court to obtain a judgment, the secured creditor can simply repossess the collateral, sell it, and keep the proceeds (up to the amount due on the debt). The secured creditor also typically moves to the front of the line in a bankruptcy proceeding. This greatly disadvantages unsecured creditors, some of whom are incapable of securing their claims against the debtor (e.g., tort victims and other involuntary creditors).

\section{Perfection of Security Interests}

Sections 9-310 through 9-316 describe the steps needed to perfect a security interest. In general, the creditor must file a financing statement recording the security interest under the debtor's name in the designated

286. The revised Article 9 became effective on July 1, 2001. All references are to the revised version of Article 9.

287. Article 9 uses the term "attach" to describe the point at which property (collateral) becomes subject to a security interest. The security interest attaches to the collateral as soon as it becomes enforceable against the debtor. UCC § 9-203(a) (2002). A security interest becomes enforceable against the debtor when value has been given by the creditor, the debtor has rights in the collateral (or power to transfer rights in the collateral to the secured creditor), and the debtor has authenticated a security agreement adequately, provided the collateral to the secured creditor (pursuant to a security agreement), or otherwise delivered a certificate (in the case of certificated security) or control of accounts (in the case of deposit accounts, electronic chattel paper, investment property, or letterof-credit rights) to the secured creditor. UCC § 9-203(b) (2002).

288. A security interest in designated collateral also extends to proceeds received upon sale or other disposal of the collateral. UCC § 9-203(f) (2002). 
state recording office. ${ }^{289}$ This allows subsequent prospective lenders to verify whether the property they seek to attach as collateral has already been attached by a prior creditor. The first entity to properly record a security interest generally has priority in resolving conflicting claims. ${ }^{290}$

\section{Federal Preemption}

Federal law can preempt state recording statutes either expressly or by implication. ${ }^{291}$ Implied preemption can arise as either (1) conflict preemption-where compliance with both the state and the federal law is impossible or where state law frustrates the achievement of federal objectives; ${ }^{292}$ or (2) field preemption - where "the scheme of federal regulation is 'so pervasive as to make reasonable the inference that Congress left no room for the States to supplement it.",293

The federal intellectual property statutes do not expressly preempt any state laws protecting security interests. However, the various registration and transfer recordation provisions of the federal intellectual property laws may preempt Article 9 under conflict or field preemption doctrines. To the extent the federal intellectual property laws do preempt Article 9, their provisions materially differ based on where and how they permit recordation and how they resolve priority disputes. For example, only Article 9 authorizes a secured creditor to attach present as well as future ("afteracquired") assets, whereas the federal intellectual property recording systems protect only specifically identified, i.e., existing, property. ${ }^{294}$ An-

289. See UCC $\S 9-310$ (a) (2002). Form UCC-1 is used for filing a security interest with a state's central filing office. Under the revised code, central filing is required in most situations. UCC $\S 9-501$ (2002).

Certain security interests do not require a filing statement if they are perfected automatically upon attachment (UCC $\S \S 9-309,9-315$ (2002)), the occurrence of another event, (UCC $\S \S 9-308(\mathrm{~d})-(\mathrm{g}), 9-313(\mathrm{e})-(\mathrm{g}), 9-315(2002))$, perfection under the law of another jurisdiction, (UCC $\S 9-316(2002)$ ), or the secured party's taking possession or control of the collateral, (UCC §§ 9-311(a), 9-312(d)(1)-(2), 9-312(e)-(g), 9-313 (2002)). UCC $\S 9-310$ (b) (2002).

290. UCC $\S 9-322(2002)$.

291. UCC $\$ 9-109$ (c)(1) provides that Article 9 does not apply to the extent that "a statute, regulation, or treaty of the United States preempts this article." Of course, the Supremacy Clause of the U.S. Constitution invalidates any state laws that "interfere, or are contrary to the laws of Congress." Gibbons v. Ogden, 22 U.S. 1, 211 (1824).

292. See Hillsborough County v. Automated Med. Lab., Inc., 471 U.S. 707, 713 (1985); Aronson v. Quick Point Pencil Co., 440 U.S. 257, 262 (1979); Kewanee Oil v. Bicron Corp., 416 U.S. 470, 479 (1973); Hines v. Davidowitz, 312 U.S. 52, 67 (1941).

293. Gade v. Nat'l Solid Wastes Mgmt. Ass'n, 505 U.S. 88, 98 (1992) (quoting Rice v. Santa Fe Elevator Corp., 331 U.S. 218, 230 (1947)).

294. See 17 U.S.C. $\$ 205(c)(1)$ (2000) (holding recordation of a document in the Copyright Office gives notice only if "the document ... specifically identifies the work 
other important difference is that the federal intellectual property statutes do not follow a strict first-to-file rule for determining priority among conflicting claimants. The Copyright Act contains a "relation-back" provision that gives a transferee a grace period for recording its interest. Under section 205 of the Copyright Act, the first (in time) transferee has priority over a second transferee (who records first) if the first transferee ultimately files within a month after execution of the transfer in the United States. ${ }^{295}$ Similarly, the Patent Act and the Lanham Act both afford assignees thirty days to record. These provisions expose subsequent purchasers to the risk that their title will be invalidated by a transfer that they could not have found through a diligent search of public files.

\section{B. Intellectual Property Statutes, Pre-emption, and Article 9}

Because implied preemption depends on the scope of the federal statute and regulations, whether a given federal intellectual property regime preempts Article 9 depends on each regime's particular nuances. Therefore, we turn to an analysis of the protection of security interests on a mode-specific basis. Since the Copyright Act provides the most extensive recordation regime among the modes of federal intellectual property protection, it raises the most significant and complex questions with regard to federal preemption. We begin our analysis there and then move on to patent, trademark, and trade secret law.

\section{Copyright}

Although the Copyright Act does not expressly address security interests in copyrights, it does provide for a detailed system for recording transfers of copyright ownership and resolving priority disputes. As discussed earlier, the Copyright Act includes within the definition of "transfer of copyright ownership" any "assignment, mortgage, exclusive license, or any other conveyance, alienation, or hypothecation of a copyright or of any of the exclusive rights comprised in a copyright, whether or not it is limited in time or place of effect, but not including a nonexclusive license." ${ }^{, 296}$ Section 205 creates the system for recording transfers of registered copyrights and resolving disputes.

The leading case on the preemptive interaction between the Copyright Act and Article 9 held that the Copyright Act's recordation system pre-

to which it pertains"); Nat'l Peregrine, Inc. v. Capitol Fed. Sav. \& Loan Ass'n (In re Peregrine Entm't, Ltd.), 116 B.R. 194, 203 n.10 (C.D. Cal. 1990); Paul Heald, Resolving Priority Disputes in Intellectual Property Collateral, 1 J. INTELl. ProP. L. 135 (1993).

295. 17 U.S.C. $\S 205(2000)$.

296. 17 U.S.C. $\S 101$ (2000 \& Supp. 2004). 
empts Article 9's with respect to registered copyrights. ${ }^{297}$ On the other hand, because the Copyright Act's recordation system cannot record interests in unregistered copyrights, Article 9's system for recording security interests remains intact for unregistered copyrights. ${ }^{298}$ In so holding, the Ninth Circuit Bankruptcy Appellate Panel explicitly overruled a series of lower court decisions that held that unregistered copyrights could not be perfected under Article $9 .^{299}$ The only wrinkle under this bright-line rule occurs when the copyright owner (who is not the party with the security interest) chooses to register the work. At that point, the Article 9 filing no longer serves to perfect the interest and must be replaced by a recordation in the Copyright Office. ${ }^{300}$ While this could create disastrous gaps in the status of a security interest, the panel believed that prudent claimants will police their debtors or require registration upfront. ${ }^{301}$ An implication of the panel's decision is that security interests in yet-to-be-created works of authorship - as would be created under "blanket liens"-can be perfected under Article 9 until their owner registers them. The court emphasized the important role that the use of security interests in works in progress can play in financing new ventures; ${ }^{302}$ by permitting perfection under Article 9 for yet-to-be-created and unregistered copyrights, the court arrived at the most efficient legal regime for perfecting security interests in copyrights. ${ }^{303}$

Copyright receivables, that is, income streams derived from copyrights, present a different problem for perfecting security interests. The court in In re Peregrine Entertainment implicitly held that copyright law preempts state law with regard to the perfection of security interests in copyright receivables. ${ }^{304}$ Although the Copyright Act does not have any specific re-

297. In re World Auxiliary Power Co., 303 F.3d 1120, 1128 (B.A.P. 9th Cir. 2002).

298. Id.

299. Id. at $1129-30$.

300. Id. at 1131-32.

301. Id.

302. Id. at 1132 .

303. Commentators have long criticized the inefficiencies of the Copyright Act recording system and the Copyright Office's delay in placing recorded interests into a publicly accessible database. Unlike the state recording systems established pursuant to Article 9 , which indexes filings by debtor, the Copyright Office arranges records by work of authorship. Therefore, a lender seeking to perfect security interests against several works owned by the debtor must make separate filings against each work separately. Where libraries of works are taken as collateral, this can amount to hundreds of separate filings. By contrast, a single filing under Article 9 would suffice to perfect security interests against all of the works.

304. See Nat'l Peregrine, Inc. v. Capitol Fed. Sav. \& Loan Ass'n (In re Peregrine Entm't, Ltd.), 116 B.R. 194 (C.D. Cal. 1990). 
cordation provision for proceeds of copyrights, Judge Kozinski based his decision on the ground that "a copyright entitles the holder to receive all income derived from the display of the creative work [under $\S 106(5)]$." 305 Following In re Peregrine Entertainment, the court in In re Avalon Software Inc. expressly held that the Copyright Act governed perfection of security interests in the proceeds of copyrights, including licenses and proceeds from licenses. ${ }^{306}$

Commentators have observed that these holdings reach beyond the stated purpose of Copyright Office recordation (which deals solely with transfers of property rights and not contract rights) ${ }^{307}$ and makes it difficult for lenders to secure debts to vendors of copyrighted works. ${ }^{308}$ Fortunately, a 1997 Ninth Circuit case undercuts, if not overrules, In re Peregrine's holding with regard to receivables. ${ }^{309}$ In Broadcast Music, Inc. v. Hirsch, a songwriter received performance right royalties from BMI. ${ }^{310}$ As a means of covering his debts, he assigned his rights to future royalty income to his creditors. The creditors did not record these security interests with the Copyright Office or perfect them under Article 9. The Internal Revenue Service later executed a tax lien on this same income stream. It argued that it had priority over unperfected security interests because tax liens are perfected upon assessment. The Ninth Circuit ruled, however, that no recording in the Copyright Office was required because the assignment of royalties did not constitute an assignment or transfer of an interest in copyright. The court distinguished In re Peregrine on the ground that Hirsch did not involve an assignment of a security interest in copyright, but rather "outright assignments of a right to receive royalties for the purpose of satisfying a debt.",311

Jordan, Warren, and Walt characterize the distinction that the Ninth Circuit draws between these two cases as "too glib." They also question the accuracy of Broadcast Music, Inc. v. Hirsch's interpretation of a "se-

305. Id. at 199.

306. See In re Avalon Software Inc., 209 B.R. 517 (Bankr. D. Ariz. 1997).

307. See Raymond T. Nimmer, Revised Article 9 and Intellectual Property Asset Financing, 53 ME. L. REV. 287, 345 (2001).

308. See Patrick R. Barry, Software Copyrights as Loan Collateral: Evaluating the Reform Proposals, 46 HASTINGS L.J. 581, 594-98 (1995); ROBERT L. JORDAN, WILLIAM D. Warren \& Steven D. Walt, Secured Transactions in Personal Property, 44344 (5th ed. 2000).

309. Broad. Music, Inc. v. Hirsch, 104 F.3d 1163, 1166 (9th Cir. 1997).

310. BMI is a performance rights organization which grants licenses to entities like television and radio stations, dance halls, hotels, and restaurants to the right to publicly perform works within its library.

311. Broad. Music, 104 F.3d at 1166 (9th Cir. 1997). 
curity interest," noting the rather broad definition under Article 9. ${ }^{312}$ Nonetheless, they opine that the implication of the decision-that security interests in copyrights would be perfected through filings pursuant to the Copyright Act and that security interests in receivables would be governed by Article 9-would represent an improvement over In re Peregrine's conclusion that security interests in both copyrights and copyright receivables must be perfected in accordance with the Copyright Act from a purely administrative perspective focused on lowering the costs of recording security interests. Nevertheless, at this point it is unclear which regime applies to the perfection of security interests in receivables. Prudent lenders wishing to secure such income streams should perfect such interests through both systems in order to assure protection. ${ }^{313}$

\section{Patents}

The Patent Act does not contain any language expressly preempting Article 9. It does, however, create a recording system, although it is substantially narrower in scope than the Copyright Act's. While the Copyright Act system applies to "transfers" broadly defined, the Patent Act's recording system is limited to "assignments, grants, and conveyances." 314

It was not until 2001 that the question of whether the Patent Act preempted Article 9 reached an appellate court. In In re Cybernetic Services, Inc. ${ }^{315}$ the Ninth Circuit ruled unequivocally that because the Patent Act recording system was limited to ownership interests in patents, and not mortgages, licenses, or hypothecations, the Act does not preempt Article 9's framework for recording security interests. ${ }^{316}$ Therefore, at least in the Ninth Circuit, Article 9 governs the perfection of security interests in patents. $^{317}$ Outside of the Ninth Circuit, it continues to be prudent for credi-

312. JORDAN ET AL., supra note 308 , at 444-45.

313. See generally Alice Haemmerli, Insecurity Interests: Where Intellectual Property and Commercial Law Collide, 96 CoLUM. L. REV. 1645 (1996).

314. 35 U.S.C. $\S 261(2000)$.

315. 252 F.3d 1039 (B.A.P. 9th Cir. 2001).

316. One commentator contends that the Ninth Circuit's decision in In re Cybernetic Servs., Inc. went too far in characterizing security interests as "mere licenses" falling completely outside of section 261's transfer protection system. See Thomas M. Ward, The Perfection and Priority Rules for Security Interests in Copyrights, Patents, and Trademarks: The Current Structural Dissonance and Proposed Legislative Cures, $53 \mathrm{ME}$. L. REV. 391 (2001). Based on the "subsequent purchaser or mortgagee" language of section 261, Ward argues that partial preemption should apply to enable the lien creditors who record their interest with the PTO, but fail to file under Article 9, to obtain protection against subsequent transferees.

317. See Pasteurized Eggs Corp. v. Bon Dente Joint Venture (In re Pasteurized Eggs Corp.), 296 B.R. 283, 290 (Bankr. D.N.H. 2003) (adopting the In re Cybernetic Servs. 
tors to file security interests with both the PTO and the appropriate state UCC office. ${ }^{318}$

\section{Trademarks}

The Lanham Act closely parallels the Patent Act with regard to recordation, creating a system limited to assignments of ownership interests. Due to the paramount importance of protecting the link between a mark and the source of the goods or services, the assignment of a trademark may only occur along with the transfer of the goodwill associated with the mark. In other respects, the Lanham Act assignment regime mirrors the Patent Act. ${ }^{319}$

As in the patent area, courts view the recordation provisions of the Lanham Act as limited to assignment of ownership interests. Therefore, they hold that the Lanham Act does not preempt Article 9 with regard to the perfection of security interests. ${ }^{320}$ Therefore, a security interest in a trademark must be perfected under state law, and a filing in the Patent and Trademark Office will not substitute for compliance with Article 9. The Lanham Act only governs recordation of "assignments" of trademark

analysis and concluding that filing of a security agreement with the PTO was insufficient to perfect creditor's security interest in debtor's patent, which was therefore subject to avoidance in exercise of debtor's strong-arm powers). Several lower courts reached similar conclusions prior to the Ninth Circuit's ruling. See City Bank \& Trust Co. v. Otto Fabric, Inc., 83 B.R. 780, 782 (D. Kan. 1988); In re Transp. Design \& Tech., Inc., 48 B.R. 635, 639 (Bankr. S.D. Cal. 1985).

318. See Haemmerli, supra note 313 , at 1659.

319. Compare 15 U.S.C. $\S 1060$ (2000 \& Supp. 2004), with 35 U.S.C. $\S 261$ (2000).

320. See Trimarchi v. Together Dev. Corp., 255 B.R. 606, 610 (Bankr. D. Mass. 2000); Joseph v. 1200 Valencia, Inc. (In re 199Z, Inc.), 137 B.R. 778 (Bankr. C.D. Cal. 1992) (reasoning that because the Lanham Act refers only to assignments and not to "pledges, mortgages, or hypothecations of trademarks," a PTO filing did not perfect the creditor's security interest in a trademark); In re Chattanooga Choo-Choo Co., 98 B.R. 792 (Bankr. E.D. Tenn. 1989) (reasoning that the Lanham Act provides only for registration of ownership, not notice of security interests, and therefore Article 9 governs perfection of a security interest in a trademark); In re C.C. \& Co., Inc., 86 B.R. 485, 487 (Bankr. E.D. Va. 1988) (reasoning that Congress did not intend Lanham Act to provide method for perfection of security interest in trade names, and lender had properly perfected its security interest in a trade name by filing financing statement under Virginia's UCC); In re Roman Cleanser Co., 43 B.R. 940 (Bankr. E.D. Mich. 1984), aff'd, 802 F.2d 207 (6th Cir. 1986) (interpreting only the Lanham Act); In re TR-3 Indus., 41 B.R. 128, 131 (Bankr. C.D. Cal. 1984) (reasoning that the omission by Congress of a registration provision for security interests in trademarks was purposeful and the recordation provision of the Lanham Act does not preempt Article 9). 
rights and the attachment of a security interest is not an assignment of rights. ${ }^{321}$

4. Trade secrets

Since trade secrets exist only under state law, there is no question of federal preemption, and therefore security interests in such assets must be perfected under state law with a UCC-1 filing. One caveat, however, is in order. As recognized by the court in In re Avalon Software Inc., ${ }^{322}$ trade secret materials often include works of authorship protected by the Copyright Act, like source code. As discussed previously, the Copyright Act preempts Article 9 with regard to registered copyrights. ${ }^{323}$ However, registering copyrights that contain trade secrets could present practical difficulties because the act of recording could disclose the trade secrets. This added complication reveals an additional benefit of the Ninth Circuit's decision in In re World Auxiliary Power Co. that the Copyright Act does not preempt Article 9 with regard to the perfection of security interests in unregistered copyrights. ${ }^{324}$ Creditors seeking to secure claims to the intellectual property embodied in source code can avoid any possible disclosure risk by simply recording the interest in a general Article 9 filing.

\section{Improving the Process for Perfecting Security Interests in Intellectual Property}

Improving the ability to securitize investments in creative ventures against intellectual property assets would reduce the risks of investment and, in so doing, promote innovation. More than a decade ago, the ABA Task Force on Security Interests in Intellectual Property observed that

The current state of the law governing security interests in intellectual property is unsatisfactory. There is uncertainty as to where and how to file, what constitutes notice of a security interest, who has priority, and what property is covered by a security interest. This area of the law is further complicated by the fact that both federal and state laws impact on these issues. ${ }^{325}$

321. Trimarchi, 255 B.R. at 610-11; In re Roman Cleanser Co., 43 B.R. at 946.

322. 209 B.R. 517 (Bankr. D. Ariz. 1997).

323. See supra notes $296-313$ and accompanying text.

324. 303 F.3d 1120 (9th Cir. 2002).

325. TASK Force ON SeCURITy INTERests IN INTEllectual Property, Business LaW Section, AMERICAN BAR AsSOCIATION, Preliminary RePORT 1 (1992). 
In March 1999, the Task Force proposed the "Federal Intellectual Property Security Act," 326 which sought to "facilitate commercial financing of enterprises based upon the security of their intellectual property" by creating a centralized federal filing system for all federally created intellectual property rights. This proposal remains on the shelf.

Several problems raise the costs and limit the efficacy of using intellectual property as collateral: confusion about whether state or federal law applies; long grace periods between registration of intellectual property and recording transfers; the morphing of intellectual property from state protection (trade secrets, unregistered copyrights) to federal protection (patents, registered copyrights). Many of these problems can be addressed through the passage of federal legislation requiring that security interests in all forms of intellectual property be centralized and integrated within a federally-administered, online, searchable database. ${ }^{327}$ The emergence of the internet along with advances in search technology ${ }^{328}$ have brought about the capacity to leapfrog over antiquated state and federal recording systems (and overlapping and sometimes conflicting rules) to a universal security interest database for all forms of intellectual property. Such a system better comports with the inherently intangible and dynamic nature of intellectual property-unlike real property or chattels, intellectual property does not typically reside in any one state and it can change over the course of its development. This approach would reduce transaction costs, enhance accessibility, and move beyond the present fragmented system.

\section{CONCLUSIONS}

The intersection of intellectual property laws with the Bankruptcy Code and Article 9 produces a daunting mix of challenging and potentially conflicting legal rules. These complexities, however, can be dissected and broken down into logical decision-making frameworks. Unfortunately, several important questions remain subject to conflicting precedent or are unresolved. Nonetheless, a structured analysis with due regard to the underlying policy values of both the Bankruptcy Code and the intellectual

326. The draft legislation can be found at http://www.abanet.org/intelprop/106legis/fipsa.html (last visited Apr. 28, 2007).

327. One such proposal has been put forward by William J. Murphy and Thomas Ward, supra note 1.

328. The Patent and Trademark Office as well as the Copyright Office have moved some of their databases online. In addition, some private enterprises-LexisNexis, Westlaw, and Google (with its patent search database) have shown that the costs of assembling and making available large, online searchable databases for intellectual property have come within reach. 
property law provides the basis for coherent resolution of these challenging questions. The time is ripe for Congress to revisit several of these issues in order to bring intellectual property laws and the bankruptcy system into greater harmony. 
BERKELEY TECHNOLOGY LAW JOURNAL 